\title{
Hydrologic and Water-Quality Data for U.S. Coast Guard Support Center Kodiak,
}

\section{Alaska, 1987-89}

by Roy L. Glass

U.S. GEOLOGICAL SURVEY

Open-File Report 96-498

Prepared in cooperation with the

U.S. COAST GUARD

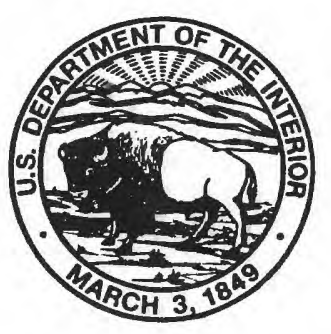

Anchorage, Alaska 


\section{U.S. DEPARTMENT OF THE INTERIOR BRUCE BABBITT, Secretary}

U.S. GEOLOGICAL SURVEY

Gordon P. Eaton, Director

Any use of trade, product, or firm names in this publication is for identification purposes

only and does not imply endorsement by the U.S. Geological Survey

For additional information write to:

\section{District Chief}

U.S. Geological Survey

4230 University Drive, Suite 201

Anchorage, AK 99508-4664
Copies of this report may be purchased from:

U.S. Geological Survey

Branch of Information Services

Box 25286

Denver, CO 80225-0286 


\section{CONTENTS}

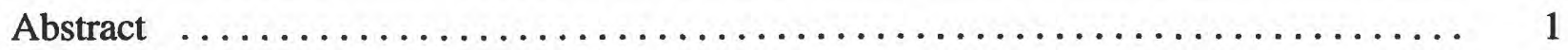

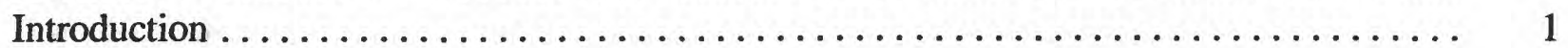

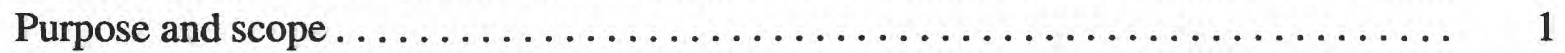

Description of study area.................................. 2

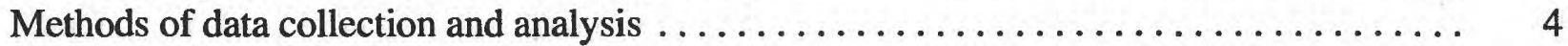

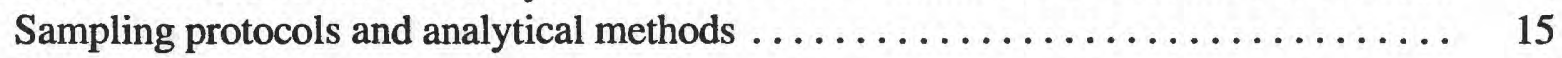

Sample collection .................................. 16

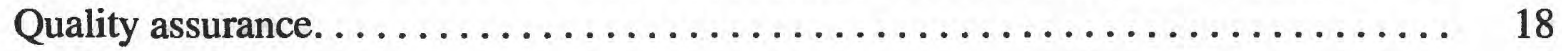

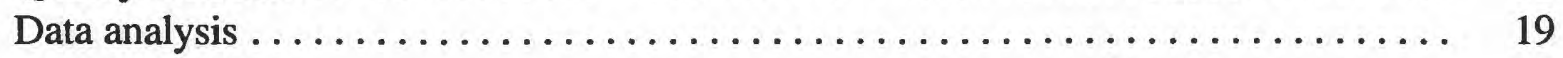

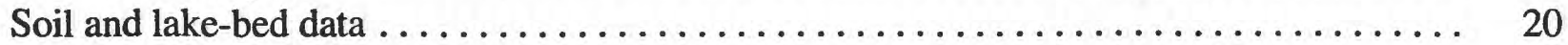

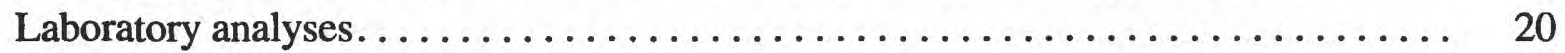

Comparisons with State guidelines ........................ 20

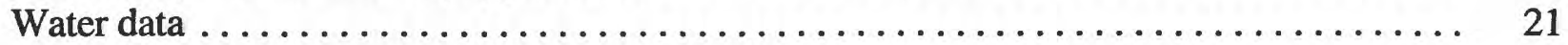

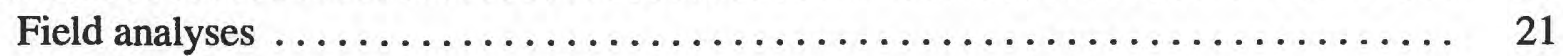

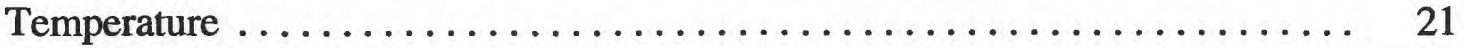

Specific conductance.............................. 21

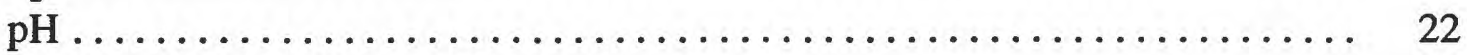

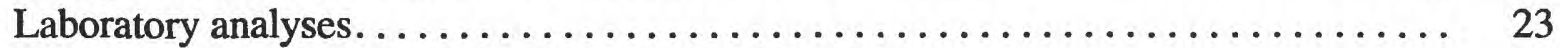

Comparisons with Federal drinking-water regulations ................. 24

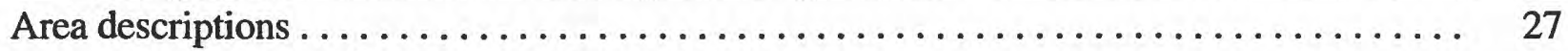

Area 19. Upgradient and background sites ........................ 27

Area 1. Former U.S. Coast Guard landfill. . . . . . . . . . . . . . . . 30

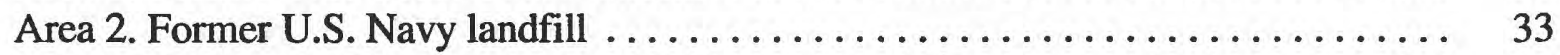

Area 3. U.S. Coast Guard laundry. ......................... 36

Area 4. Former diesel storage area.......................... 39

Area 5. Former fire-fighting training area....................... 41

Area 6. Fuel storage areas on Nyman Peninsula. ................... 43

Area 7. Former drum storage areas on Nyman Peninsula.............. 46

Area 8. Battery storage areas on Nyman Peninsula .................. 49

Area 9. Former aviation gasoline storage area on Nyman Peninsula .......... 52

Area 10. Air station ..................................... 54

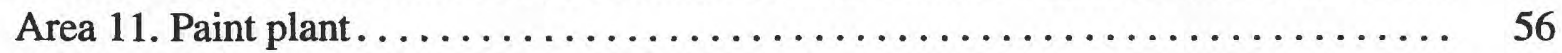

Area 12. Drum disposal area west of Buskin Lake................. 57

Area 13. Drum disposal area northwest of Buskin Lake............... 59

Area 14. Former quartermaster gasoline station ................... 60

Area 15. Former gasoline station. . . . . . . . . . . . 62

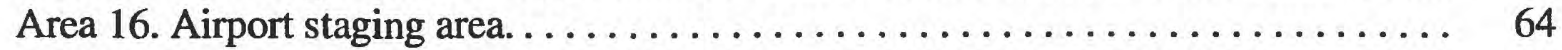

Area 17. Storage pad south of steam plant $\ldots \ldots \ldots \ldots \ldots \ldots \ldots \ldots \ldots \ldots, 66$

Area 18. Former metal disposal area............................ 68

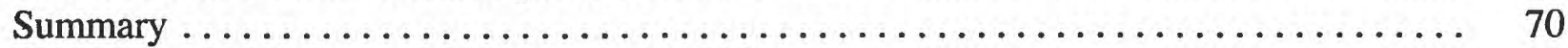

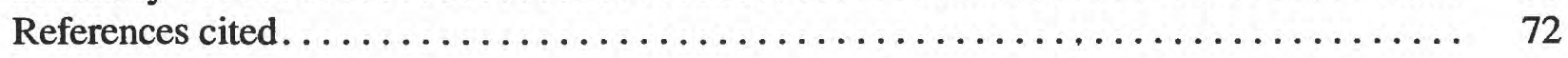

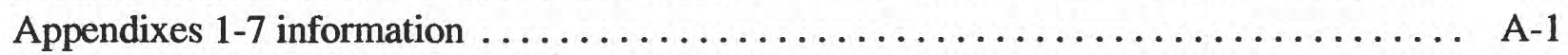

[Appendixes are on disks included with report] 


\section{FIGURES}

1-21. Maps showing:

1. Location of Kodiak Island, Alaska, and study area .............. VI

2. Location of areas of possible contamination at the U.S. Coast Guard Support

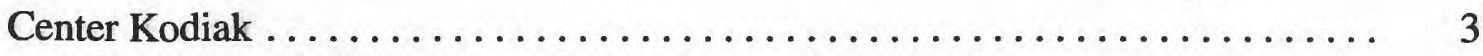

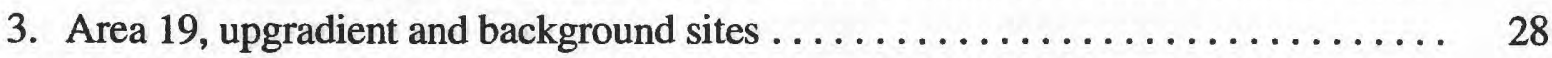

4. Area 1, the former U.S. Coast Guard landfill.................. 31

5. Area 2 , the former U.S. Navy landfill. ................... 34

6. Area 3, the U.S. Coast Guard laundry .................... 37

7. Area 4, a former U.S. Army diesel storage area................ 40

8. Area 5 , a former fire-fighting training area $\ldots \ldots \ldots \ldots \ldots \ldots \ldots \ldots \ldots \ldots$

9. Area 6, the fuel tank area on Nyman Peninsula................... 44

10. Area 7, former drum storage areas on Nyman Peninsula . . . . . . . . . . 47

11. Area 8 , the battery storage areas on Nyman Peninsula . . . . . . . . . 50

12. Area 9, the former aviation gasoline storage area on Nyman Peninsula ....... 53

13. Area 10 , the air station . . . . . . . . . . . . 55

14. Area 11, the paint plant. . . . . . . . . . . . . . . . 56

15. Area 12, a former drum disposal area near Buskin Lake . . . . . . . . . 58

16. Area 13, a former drum disposal area near Buskin Lake . . . . . . . . . . . 59

17. Area 14 , the former quartermaster gasoline station $\ldots \ldots \ldots \ldots \ldots \ldots \ldots \ldots \ldots$

18. Area 15 , a former gasoline station $\ldots \ldots \ldots \ldots \ldots \ldots \ldots \ldots \ldots \ldots \ldots \ldots \ldots$

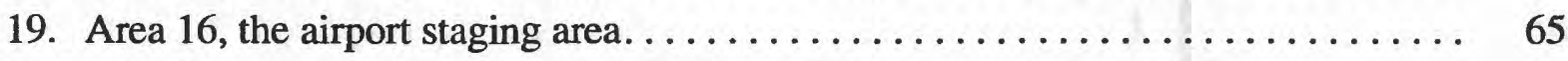

20. Area 17, a storage pad south of the steam plant ............... 67

21. Area 18 , a former metal disposal area. .................... 69

\section{TABLES}

1. Location and description of surface-water data-collection sites. . . . . . . . 5

2. Location and description of soil and ground-water data-collection sites. ...... 7 


\begin{tabular}{rll}
\hline Multiply & by & To obtain \\
\hline inch (in.) & 25.4 & millimeter \\
foot (ft) & 0.3048 & meter \\
mile (mi) & 1.609 & kilometer \\
square mile $\left(\mathrm{mi}^{2}\right)$ & 2.590 & square kilometer \\
cubic foot per second ( $\left.\mathrm{ft}^{3} / \mathrm{s}\right)$ & 0.02832 & cubic meter per second \\
gallon (gal) & 3.785 & liter \\
\hline
\end{tabular}

In this report, air temperature is reported in degrees Fahrenheit $\left({ }^{\circ} \mathrm{F}\right)$, which can be converted to degrees Celsius $\left({ }^{\circ} \mathrm{C}\right)$ by the following equation:

$$
{ }^{\circ} \mathrm{F}=1.8\left({ }^{\circ} \mathrm{C}\right)+32
$$

Water temperature is reported in degrees Celsius $\left({ }^{\circ} \mathrm{C}\right)$.

\section{Other abbreviations in this report are:}

$\mathrm{mL}$, milliliter

$\mathrm{mg} / \mathrm{kg}$, milligram per kilogram

$\mu \mathrm{g} / \mathrm{kg}$, microgram per kilogram

$\mathrm{mg} / \mathrm{L}$, milligram per liter

$\mu \mathrm{g} / \mathrm{L}$, microgram per liter

$\mu \mathrm{S} / \mathrm{cm}$, microsiemen per centimeter at $25^{\circ} \mathrm{Celsius}$

\section{Elevation datum:}

Mean Sea Level: In this report, mean sea level refers to a tidal datum midway between the arithmetic means of the high-water heights and low-water heights for the Kodiak Island tidal station. This is also called mean tide level.

\section{Notes:}

Dates are listed in the format YEAR MONTH DAY. For example, 891225 represents December 25, 1989.

A Chemical Abstract Service (CAS) reference number is a unique identifier assigned by the American Chemical Society to chemicals recorded in the Chemical Abstracts Service Registry system. This number can be used to access many chemical databases and to conclusively identify a substance regardless of name. In this report, a Chemical Abstract Service (CAS) number is assigned to each water property or constituent. The format of a CAS number is typically XXX-XX-X, but the dashes are omitted in this report (71-43-2 is reported as 71432). In this report, CAS numbers less than 1000 represent field properties, not chemicals. 


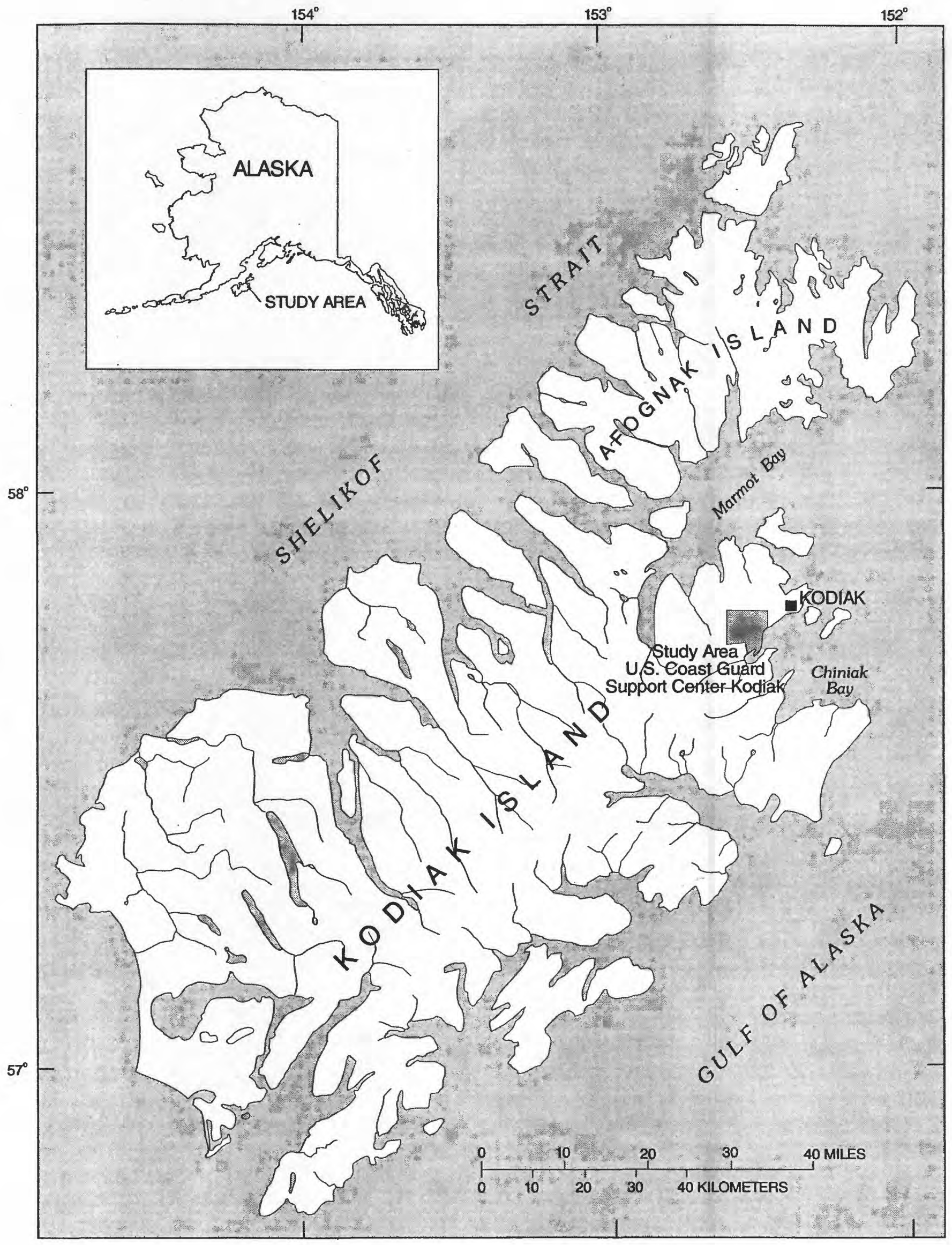

Figure 1. Location of Kodiak Island, Alaska and study area. 


\title{
Hydrologic and Water-Quality Data for U.S. Coast Guard Support Center Kodiak, Alaska, 1987-89
}

\author{
by Roy L. Glass
}

\section{ABSTRACT}

Hydrologic and water-quality data were collected at the U.S. Coast Guard Support Center Kodiak on Kodiak Island, Alaska, to determine regional ground-water conditions and if contamination of soils, ground water, or surface water has occurred. Eighteen areas of possible contamination were identified. Ground-water levels, surface-water stages, surface-water discharges, and results of field and laboratory analyses of soil and water samples are presented in tabular form.

Many quality-assurance samples had detectable concentrations of methylene chloride and 1,2-dichloroethane, which may be due to sampling or laboratory contamination. Concentrations were as great as 5.9 micrograms per liter for methylene chloride and 2.6 micrograms per liter for 1,2-dichloroethane. Excluding 1,2-dichloroethane, most soil, ground-water, and surface-water samples contained no detectable concentrations of the organic constituents that were analyzed.

Chemical analyses were performed on two lake-bed-material samples and more than 100 soil samples. The median lead concentration was 9.8 milligrams per kilogram. Concentrations of tetrachloroethene were as great as $\mathbf{1 . 1}$ milligram per kilogram in soils near a laundry.

Water samples were collected from 101 wells. The maximum benzene concentration detected in ground water was 78 micrograms per liter from a well at the air station near a site where aviation fuel was spilled. Wells near a laundry yielded water having concentrations of tetrachloroethene as great as 3,000 micrograms per liter, and vinyl chloride as great as $\mathbf{4 4 0}$ micrograms per liter. A well in a former aviation gasoline storage area yielded water with a concentration of trichloroethene as great as $\mathbf{6 6}$ micrograms per liter.

Water samples were collected from 59 sites on streams, lakes, or ponds. Surface-water samples had much lower concentrations of organic compounds; the highest concentration of benzene was 2.2 micrograms per liter in a stream near a former aviation-fuel storage area and the maximum vinyl chloride concentration was $\mathbf{1 5}$ micrograms per liter in a stream near a former landfill. Tetrachloroethene and trichloroethene were not detected in any surface-water samples.

\section{INTRODUCTION}

The U.S. Coast Guard (USCG) Support Center (referred to as "Center" in this report), on the east coast of Kodiak Island in southcentral Alaska (fig. 1), was established during World War II as a U.S. Navy Base. It covers about $55 \mathrm{mi}^{2}$ and it served as a U.S. Navy submarine base, air station, and port during and after the war. In 1972, the Navy transferred the station to the USCG.

\section{Purpose and Scope}

The U.S. Geological Survey (USGS), at the request of the USCG, began a study of geologic and hydrologic conditions at the Center and adjacent areas in February 1987. The investigation was prompted by the need to evaluate environmental conditions related to historical waste-disposal practices or spills. Areas where soil and water contamination may have occurred include fuel and 
hazardous-material storage areas, landfills, metal-disposal and fire-fighting training areas, and a laundry facility. The general locations of 18 areas of potential contamination are shown in figure 2. Areas thought not to be contaminated and not downgradient of potentially contaminated areas are treated as a single area (Area 19) in this report. The sections of this report describing these areas have maps that show in greater detail the location of surface-water, well, and soil sampling sites. This report lists soil and water data collected on the Center by the USGS during 1987-89 and briefly discusses some of the chemical constituents detected in the areas of potential contamination. Other published reports of this investigation include those by Allely (1989), Brown (1989), Carr (1996), Combellick (1989), Solie and Reifenstuhl (1989), and Solin (1996). Much of the data resulting from this study are in appendixes on the disks included with this report.

\section{Description of Study Area}

Steep, rugged, and extensively glaciated terrain characterizes most of Kodiak Island, including areas near and within the Center. Ground elevations range from sea level to $2,482 \mathrm{ft}$ above sea level at Barometer Mountain (fig. 2). Bedrock is exposed throughout much of the Center and is predominantly metamorphosed sedimentary and volcanic rocks. Only limited amounts of unconsolidated materials are present, thus restricting the availability of ground water for use as a water supply. The primary source of water for the Center is Buskin Lake (fig. 2). One well (CG 4) supplies water to the Buskin River Beach House (Building 101), 0.2 mi north of the mouth of the Buskin River.

Kodiak Island is in the maritime climate zone which is characterized by moderate diurnal and annual temperature ranges. Weather data have been collected near the airport's control tower near the center of the airport since 1973 . The average temperature was $41^{\circ} \mathrm{F}$ during $1973-87$ (Leslie, 1987). Mean monthly temperatures for 1987,1988 , and 1989 (National Oceanic and Atmospheric Administration, 1987-89), the period of the investigation, were:

\begin{tabular}{lccc}
\hline & \multicolumn{4}{c}{ Mean monthly temperature } \\
Month & $\begin{array}{l}\text { Megrees Fahrenheit) } \\
\text { (deg8 }\end{array}$ & 1987 & 1989 \\
\hline & & & \\
& & & \\
January & 34.0 & 32.2 & 21.7 \\
February & 36.2 & 34.3 & 33.0 \\
March & 35.4 & 34.7 & 33.1 \\
Apri1 & 38.1 & 36.8 & 39.3 \\
May & 44.8 & 45.0 & 44.9 \\
June & 47.7 & 51.6 & 50.3 \\
July & 55.9 & 54.1 & 57.4 \\
August & 56.5 & 55.1 & 57.2 \\
September & 48.4 & 48.7 & 52.0 \\
October & 41.8 & 41.2 & 41.2 \\
November & 33.3 & 32.7 & 32.2 \\
December & 28.0 & 30.4 & 34.6 \\
Mean & 41.7 & 41.4 & 41.4 \\
\hline
\end{tabular}

Mean annual precipitation (as inches of moisture, includes both rain and snow), is about 74 in. Mean annual snowfall is about 66 in. (Leslie, 1989). Total monthly and yearly precipitation for 1987, 1988, and 1989 (National Oceanic and Atmospheric Administration, 1987-89) were: 


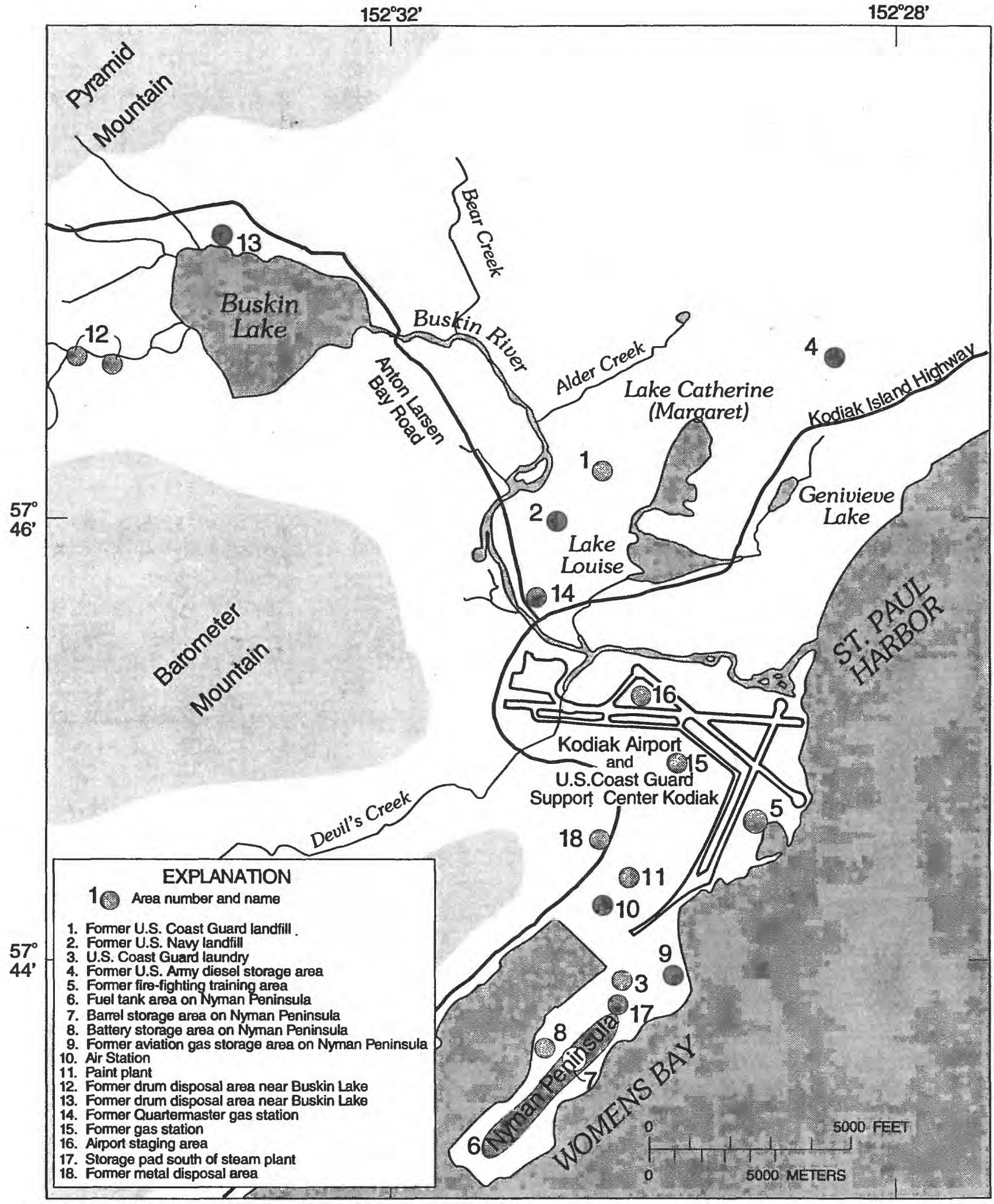

Base from U.S. Geological Survey, Kodiak, Alaska, 1:250,000, 1952

Figure 2. Location of areas of possible contamination at the U.S. Coast Guard Support Center Kodiak. 


\begin{tabular}{|c|c|c|c|}
\hline \multirow[t]{2}{*}{ Month } & \multicolumn{3}{|c|}{$\begin{array}{l}\text { Monthly precipitation } \\
\text { (inches) }\end{array}$} \\
\hline & 1987 & 1988 & 1989 \\
\hline January & 10.21 & 6.91 & 2.53 \\
\hline February & 4.75 & 11.50 & 1.44 \\
\hline March & 6.31 & 8.59 & 3.61 \\
\hline April & 4.93 & 6.65 & 4.18 \\
\hline May & 3.67 & 2.42 & 2.01 \\
\hline June & 16.88 & 1.59 & 7.22 \\
\hline July & 1.25 & 4.11 & 3.87 \\
\hline August & 0.65 & 8.28 & 5.46 \\
\hline September & 7.83 & 6.55 & 6.37 \\
\hline October & 8.08 & 10.20 & 7.04 \\
\hline November & 4.98 & 7.93 & 5.58 \\
\hline December & 2.49 & 11.48 & 12.48 \\
\hline Total & 72.03 & 86.21 & 61.79 \\
\hline
\end{tabular}

\section{METHODS OF DATA COLLECTION AND ANALYSIS}

In order to investigate contamination at the Center, USGS personnel interviewed persons knowledgeable about the Center's past and present storage and handling procedures for hazardous wastes and fuels. A soil-gas survey was conducted in 1987 using an organic vapor analyzer (J.O. Brunett, U.S. Geological Survey, written commun., 1989). Soil-gas samples were collected over a 200- by 200-foot grid covering most of the Nyman Peninsula and other areas of suspected contamination. In areas where organic vapor concentrations exceeded threshold levels or in areas identified as possibly contaminated, monitoring wells were drilled using a hollow-stem auger or an airrotary drilling rig so that ground water could be sampled. Where possible, additional wells were placed upgradient and downgradient from these potentially contaminated sites.

Data-collection sites are listed in table 1 (surface water and lake-bed material) and table 2 (soil and ground water). Site types listed as "SW" are streams, ponds or lakes; "SL" sites are where lake-bed or soil samples were collected; "GW" sites are wells where ground-water samples were collected or measurements of ground-water levels were made; and "TW" are sites where water samples from the water-distribution system were collected. Most sites are classified as being upgradient or downgradient from one or more potentially contaminated sites. A stream or well may be upgradient from one potentially contaminated area and downgradient from another.

Upgradient sites were not available at all identified areas of potential contamination for the following reasons: the area was on a hilltop, bedrock was exposed at the land surface, a flowing stream was not present, or places upgradient could not be reached by the drill rigs used. A site was considered downgradient if it was within an area of potential contamination or if it could reasonably be expected to detect changes in water quality from the area of potential contamination. Many areas of potential contamination on Nyman Peninsula and the airport are near or adjacent to the brackish waters of Womens Bay, thus many downgradient surface-water and ground-water sites may be greatly influenced by saltwater or by marine sediments. Surface-water sites possibly influenced by brackish tidewaters include sites $34,35,38,47,49,50$, and 54 . Wells in tidal areas or wells drilled into sediments once inundated by brackish waters may also yield waters that contain high concentrations of minerals. Wells possibly influenced by brackish waters include A018, A034, A037, A042, A044, and A086. 
Table 1. Location and description of surface-water data-collection sites, U.S. Coast Guard Support Center Kodiak

[Site type: SL, soil or lake-bed material; SW, surface water; TW, treated water; * indicates water elevation only, no water quality data was obtained at the site. Area: $D$, downgradient; U, upgradient. -, not applicable]

\begin{tabular}{|c|c|c|c|c|}
\hline $\begin{array}{l}\text { Site } \\
\text { No. }\end{array}$ & $\begin{array}{l}\text { USGS station } \\
\text { number }\end{array}$ & Station name & Site type & Area \\
\hline 1 & 574658152332600 & Buskin Lake Tributary (North-northwest) & SW & 13D \\
\hline 2 & 574654152333600 & Buskin Lake Tributary (Northwest) & SW & $19 U$ \\
\hline 3 & 574646152333700 & Buskin Lake Tributary (West) & SW & $19 U$ \\
\hline 4 & 574640152324600 & Buskin Lake (Station 1) & SW & $19 U$ \\
\hline 5 & 574640152312300 & Bear Creek at mouth & SW & $19 U$ \\
\hline 6 & 574638152331000 & Buskin Lake (Station 2) & sw & $19 U$ \\
\hline 7 & 574636152314200 & Buskin River below lake & Sw & $19 U$ \\
\hline 8 & 574635152283400 & Unnamed Creek at Building 477 above substation & SW & 04D \\
\hline 9 & 574633152283400 & Unnamed Creek above Building 477 Road & sw & 04D \\
\hline 10 & 574633152283800 & Unnamed Creek below Transformer Substation & SW & 04D \\
\hline 11 & 574635152300500 & Alder Creek at BB Road & sw & $19 U$ \\
\hline 12 & 574638152333000 & Buskin Lake Tributary (Southwest 1) & SW & 12D \\
\hline 13 & 574637152332800 & Buskin Lake Tributary (Southwest 2) & SW & 12D \\
\hline 14 & 574628152310400 & Buskin River 0.9 mile below Buskin Lake & SW & $19 U$ \\
\hline 15 & 574624152303200 & Alder Creek at G Road & Sw & $19 U$ \\
\hline 16 & 574612152304500 & Unnamed Tributary 1 to Buskin River & sw & $19 U$ \\
\hline 17 & 574612152304300 & Buskin River 1.3 mile below Buskin Lake & sw & 01D \\
\hline 18 & 574610152311700 & Magazine Creek at 0.9 mile Anton Larsen Bay Road & sw & $19 \mathrm{U}$ \\
\hline 19 & 574603152303000 & Coast Guard Landfill Drain North & Sw & $01 \mathrm{D}$ \\
\hline 20 & 574558152302200 & Coast Guard Landfill Drain East & sw & 01D \\
\hline 21 & 574559152310400 & Buskin River at Bridge 6 & SW & 01D \\
\hline 22 & 574553152302700 & Coast Guard Landfill Drain South & SW & $01 \mathrm{D}$ \\
\hline 23 & 574553152305200 & Landfill Pond North of Red Lake & SW & 02D \\
\hline 24 & 574546152304200 & Red Lake Inlet Ditch Southeast & sW & 02D \\
\hline 25 & 574547152305000 & Red Lake & SW & 02D \\
\hline 25 & 574547152305000 & Red Lake (Bed material) & SL & 02D \\
\hline 26 & 574548152305400 & Red Lake Outlet West & sw & 02D \\
\hline 27 & 574538152301000 & Lake Louise Outlet & SW & $19 U$ \\
\hline 28 & 574536152310900 & Unnamed Tributary 2 to Buskin River & SW & $19 U$ \\
\hline 29 & 574530152304600 & Buskin River at Kodiak Island Highway & SW & 02D 14D \\
\hline 30 & 574522152294000 & Buskin River near mouth below Bridge 2 & sw & 16D 02D 14D \\
\hline 31 & 574522152303800 & Devils Creek below runway near mouth & sw & 16D \\
\hline 32 & 574505152304200 & Devils Creek above runway below highway & sw & $16 U 19 U$ \\
\hline
\end{tabular}


Table 1. Location and description of surface-water data-collection sites, U.S. Coast Guard Support Center Kodiak--Continued

[Site type: SL, soil or lake-bed material; SW, surface water; TW, treated water; * indicates water elevation only, no water quality data was obtained at the site. Area: D, downgradient; U, upgradient. -, not applicable]

\begin{tabular}{|c|c|c|c|c|}
\hline $\begin{array}{l}\text { Site } \\
\text { No. }\end{array}$ & $\begin{array}{l}\text { USGS station } \\
\text { number }\end{array}$ & Station name & Site type & Area \\
\hline 33 & 574446152300000 & Drury Gulch at Kodiak Island Highway & SW & $18 \mathrm{D}$ \\
\hline 34 & 574446152285300 & Kodiak Airport Drainage Site 3 & SW & 05D 16D \\
\hline 35 & 574436152290800 & Kodiak Airport Drainage Site 1 & SW & $16 \mathrm{D}$ \\
\hline 36 & 574429152292000 & Kodiak Airport Drainage Site A & SW & $16 \mathrm{D}$ \\
\hline 37 & 574409152293600 & Nyman Peninsula Drainage Site 9 & SW & 09D \\
\hline 38 & 574408152301000 & Nyman Peninsula Drainage Site 1 & SW & $10 \mathrm{D}$ \\
\hline 39 & 574405152293300 & Nyman Peninsula Drainage Site 8 & SW & 09D \\
\hline 40 & 574358152302000 & Nyman Peninsula Drainage Site 2 & SW & 06D 17D \\
\hline 41 & 574355152294500 & Nyman Peninsula Drainage Site 6a & SW & 09D \\
\hline 42 & 574351152304100 & Nyman Peninsula Drainage Site 2a & SW & 06D 08D 07D \\
\hline 43 & 574345152301200 & Nyman Peninsula Drainage Site 6 & SW & 06D \\
\hline 44 & 574344152301500 & Nyman Peninsula Drainage Site 5a & SW & 06D 07D \\
\hline 45 & 574342152304800 & Nyman Peninsula Drainage Site 3 & SW & 06D \\
\hline 46 & 574341152302400 & Nyman Peninsula Drainage Site 7 Tank & SW & 06D \\
\hline 47 & 574337152305000 & Nyman Peninsula Drainage Site 3a & SW & 06D \\
\hline 48 & 574335152305200 & Nyman Peninsula Drainage Site $3 b$ & SW & 06D \\
\hline 49 & 574333152302800 & Nyman Peninsula Drainage Site 5 & SW & $06 \mathrm{D}$ \\
\hline 50 & 574323152311500 & Nyman Peninsula Drainage Site $3 c$ & SW & 06D \\
\hline 51 & 574322152304600 & Peninsula Lake & SW & 06D \\
\hline 51 & 574322152304600 & Peninsula Lake (Bed material) & SL & 06D \\
\hline 52 & 574325152305200 & Peninsula Lake Inlet Nyman Peninsula & sw & $06 \mathrm{D}$ \\
\hline 53 & 574314152311400 & Nyman Peninsula Drainage Site 3d & SW & 06D \\
\hline 54 & 574313152311600 & Nyman Peninsula Drainage Site 4 & SW & 06D \\
\hline 55 & 574700152330000 & Unnamed Creek north of Buskin Lake & sw & $19 U$ \\
\hline 56 & 574640152321100 & Buskin Lake elevation site & SW* & - \\
\hline 57 & 574600152295200 & Catherine (Margaret) Lake & SW & $19 U$ \\
\hline 58 & 574600152290000 & Genevieve Lake & SW & $19 U$ \\
\hline 59 & 574551152300300 & Lake Louise elevation site & SW* & - \\
\hline 60 & 15297440 & Buskin River & sw & $16 \mathrm{D}$ \\
\hline 61 & 15297439 & Devils Creek & sw & $19 U$ \\
\hline TW 1 & 574633152315001 & Treated water 1--water-treatment-plant faucet & TW & - \\
\hline TW 2 & 574526152304501 & Treated water 2--hotel faucet & TW & - \\
\hline
\end{tabular}


Table 2. Location and description of soil and ground-water data-collection sites, U.S. Coast Guard Support Center Kodiak

[Site type: GW, ground water; SL, soil or lake-bed material; * indicates water elevation only, no water quality data was obtained at the site. Area: D, downgradient; U, upgradient. -, not applicable]

\begin{tabular}{|c|c|c|c|c|c|c|c|c|c|}
\hline Site No. & $\begin{array}{l}\text { USGS Station } \\
\text { number }\end{array}$ & $\begin{array}{l}\text { Site } \\
\text { type }\end{array}$ & Area & $\begin{array}{l}\text { Land- } \\
\text { surface } \\
\text { altitude } \\
\text { (feet) }\end{array}$ & $\begin{array}{l}\text { Well } \\
\text { depth } \\
\text { (feet) }\end{array}$ & $\begin{array}{c}\text { Well } \\
\text { diam- } \\
\text { eter } \\
\text { (inches) }\end{array}$ & $\begin{array}{l}\text { Screen } \\
\text { top } \\
\text { (feet) }\end{array}$ & $\begin{array}{c}\text { Screen } \\
\text { bottom } \\
\text { (feet) }\end{array}$ & $\begin{array}{c}\text { Construc- } \\
\text { tion } \\
\text { date }\end{array}$ \\
\hline $\mathrm{A} 001$ & 574630152341601 & GW & $12 \mathrm{D}$ & 92 & 17.60 & 2 & 7.6 & 17.6 & 890520 \\
\hline $\mathrm{A} 001-00.5$ & 574630152341601 & SL & 12D & - & - & - & - & - & 890520 \\
\hline A001-03 & 574630152341601 & SL & $12 \mathrm{D}$ & - & - & - & - & - & 890520 \\
\hline A001-07 & 574630152341601 & SL & 12D & - & - & - & - & - & 890520 \\
\hline $\mathrm{A} 001 \mathrm{~A}$ & 574630152340101 & GW & $12 \mathrm{D}$ & 84 & 14.5 & 2 & 4.5 & 14.5 & 890520 \\
\hline $\mathrm{A} 001 \mathrm{~A}-02.5$ & 574630152340101 & SL & 12D & - & - & - & - & - & 890520 \\
\hline A001A-08 & 574630152340101 & SL & 12D & - & - & - & - & - & 890520 \\
\hline $\mathrm{A} 002 \mathrm{~A}$ & 574626152320801 & GW & $19 U$ & 82.5 & 7. & 2 & 2. & 7. & 880419 \\
\hline A002A-05 & 574626152320801 & SL & $19 \mathrm{U}$ & - & - & - & - & - & 880419 \\
\hline A003 & 574626152313301 & GW & $19 U$ & 68.3 & 22. & 2 & 0. & 22. & 880115 \\
\hline $\mathrm{A} 004$ & 574654152312401 & GW & $19 U$ & 82.3 & 19. & 2 & 9. & 19. & 880116 \\
\hline A005 & 574540152313601 & GW & $19 U$ & 134.5 & 14.5 & 2 & 4.5 & 14.5 & 880120 \\
\hline A006 & 574554152310601 & GW & $02 \mathrm{D}$ & 36.1 & 15.5 & 2 & 3.5 & 15.5 & 880118 \\
\hline $\mathrm{A} 006 \mathrm{~A}$ & 574554152305901 & GW & 02D & 36.2 & 9. & 2 & 1. & 6. & 880421 \\
\hline A006A-05 & 574554152305901 & SL & 02D & - & - & - & - & - & 880421 \\
\hline $\mathrm{A} 007$ & 574605152304101 & GW & $01 \mathrm{D}$ & 44.7 & 18.5 & 2 & 3.5 & 18.5 & 880118 \\
\hline A008 & 574522152304801 & GW & $16 \mathrm{D}$ & 44.6 & 37.5 & 2 & 17.5 & 37.5 & 880419 \\
\hline A009 & 574536152302301 & GW & $19 U$ & 24.4 & 12. & 2 & 1. & 12. & 880121 \\
\hline A010 & 574553152300901 & GW & $19 U$ & 28. & 19.5 & 2 & 4.5 & 19.5 & 880119 \\
\hline A010A & 574602152301701 & GW & $01 D$ & 75.4 & 13.5 & 2 & 3.5 & 13.5 & 880419 \\
\hline$A 010 A-05$ & 574602152301701 & SL & 01D & - & - & - & - & - & 880419 \\
\hline A011 & 574504152304201 & GW & $16 \mathrm{D}$ & 66.2 & 5.5 & 2 & 0.5 & 5.5 & 880218 \\
\hline A011-05 & 574504152304201 & SL & $16 \mathrm{D}$ & - & - & - & - & - & 880218 \\
\hline A012 & 574519152293901 & GW & $16 \mathrm{D}$ & 16.5 & 27. & 2 & 17. & 27. & 880217 \\
\hline A012-10 & 574519152293901 & SL & $16 \mathrm{D}$ & - & - & - & - & - & 880217 \\
\hline A012A & 574520152295301 & GW & $16 \mathrm{D}$ & 24. & 25. & 2 & 15. & 25. & 880418 \\
\hline
\end{tabular}


Table 2. Location and description of soil and ground-water data-collection sites, U.S. Coast Guard Support Center Kodiak--Continued

[Site type: GW, ground water; SL, soil or lake-bed material; * indicates water elevation only, no water quality data was obtained at the site. Area: D, downgradient; U, upgradient. -, not applicable]

\begin{tabular}{|c|c|c|c|c|c|c|c|c|c|}
\hline Site No. & $\begin{array}{l}\text { USGS Station } \\
\text { number }\end{array}$ & $\begin{array}{l}\text { Site } \\
\text { type }\end{array}$ & Area & $\begin{array}{l}\text { Land- } \\
\text { surface } \\
\text { altitude } \\
\text { (feet) }\end{array}$ & $\begin{array}{l}\text { Well } \\
\text { depth } \\
\text { (feet) }\end{array}$ & $\begin{array}{l}\text { Well } \\
\text { diam- } \\
\text { eter } \\
\text { (inches) }\end{array}$ & $\begin{array}{c}\text { Screen } \\
\text { top } \\
\text { (feet) }\end{array}$ & $\begin{array}{c}\text { Screen } \\
\text { bottom } \\
\text { (feet) }\end{array}$ & $\begin{array}{l}\text { Construc- } \\
\text { tion } \\
\text { date }\end{array}$ \\
\hline A012A-15 & 574520152295301 & SL & 16D & - & - & - & - & - & 880418 \\
\hline $\mathrm{A} 013$ & 574514152291501 & GW & 16D & 17.4 & 25. & 2 & 15. & 25. & 880218 \\
\hline A013-10 & 574514152291501 & SL & $16 \mathrm{D}$ & - & - & - & - & - & 880218 \\
\hline A014 & 574425152302001 & GW & 10D & 35.2 & 46. & 2 & 41. & 46. & 880127 \\
\hline A014-15 & 574425152302001 & SL & 10D & - & - & - & - & - & 880127 \\
\hline A015 & 574442152295501 & GW & $19 U$ & 53.9 & 42.5 & 2 & 27.5 & 42.5 & 880125 \\
\hline A016 & 574450152295201 & GW & $15 \mathrm{U}, 18 \mathrm{D}$ & 51.5 & 26.5 & 2 & 16.5 & 26.5 & 880123 \\
\hline A017 & 574501152293601 & GW & 15D & 36. & 34.5 & 2 & 24.5 & 34.5 & 880123 \\
\hline A018 & 574420152301201 & GW & 10D & 13.9 & 23. & 2 & 18. & 23. & 880216 \\
\hline A018-09 & 574420152301201 & SL & 10D & - & - & - & - & - & 880216 \\
\hline A019 & 574432152295001 & GW & $19 U$ & 28.4 & 19. & 2 & 14. & 19. & 880126 \\
\hline A020 & 574448152292301 & GW & $19 \mathrm{U}$ & 60.7 & 21.5 & 2 & 16.5 & 21.5 & 880126 \\
\hline A020A & 574442152292801 & GW & $16 \mathrm{D}$ & 31.2 & 28.5 & 2 & 8.5 & 28.5 & 880417 \\
\hline A020A-05 & 574442152292801 & SL & 16D & - & - & - & - & - & 880417 \\
\hline A021 & 574414152295701 & $\mathrm{GW}^{*}$ & 10D & 12.3 & 11. & 2 & 6. & 11. & 880216 \\
\hline A021-09 & 574414152295701 & SL & 10D & - & - & - & - & - & 880216 \\
\hline A021A & 574412152295901 & GW & 10D & 12.4 & 20. & 2 & 5. & 20. & 880420 \\
\hline A021A-05 & 574412152295901 & SL & 10D & - & - & - & - & - & 880420 \\
\hline A022A-05 & 574427152293401 & SL & 16D & - & - & - & - & - & 880417 \\
\hline A023A & 574444152290301 & GW & 05D, 16D & 10.3 & 23.5 & 2 & 8.5 & 23.5 & 880417 \\
\hline A023A-05 & 574444152290301 & SL & 05D, 16D & - & - & - & - & - & 880417 \\
\hline A024 & 574636152283401 & GW & 04D & 189.4 & 16. & 2 & 1. & 16. & 880218 \\
\hline A024-03 & 574636152283401 & SL & 04D & - & - & - & - & - & 880218 \\
\hline A025 & 574407152300901 & GW & 06D, 10D & 16.1 & 7. & 2 & 2. & 7. & 880217 \\
\hline A025-05 & 574407152300901 & SL & 06D, 10D & - & - & - & - & - & 880217 \\
\hline A026 & 574405152300801 & GW & 06D & 20.1 & 9. & 2 & 4. & 9. & 880214 \\
\hline A026-05 & 574405152300801 & SL & $06 \mathrm{D}$ & - & - & - & : & - & 880214 \\
\hline
\end{tabular}


Table 2. Location and description of soil and ground-water data-collection sites, U.S. Coast Guard Support Center Kodiak--Continued

[Site type: GW, ground water; SL, soil or lake-bed material; * indicates water elevation only, no water quality data was obtained at the site. Area: D, downgradient; U, upgradient. -, not applicable]

\begin{tabular}{|c|c|c|c|c|c|c|c|c|c|}
\hline Site No. & $\begin{array}{l}\text { USGS Station } \\
\text { number }\end{array}$ & $\begin{array}{l}\text { Site } \\
\text { type }\end{array}$ & Area & $\begin{array}{l}\text { Land- } \\
\text { surface } \\
\text { altitude } \\
\text { (feet) }\end{array}$ & $\begin{array}{l}\text { Well } \\
\text { depth } \\
\text { (feet) }\end{array}$ & $\begin{array}{l}\text { Well } \\
\text { diam- } \\
\text { eter } \\
\text { (inches) }\end{array}$ & $\begin{array}{c}\text { Screen } \\
\text { top } \\
\text { (feet) }\end{array}$ & $\begin{array}{c}\text { Screen } \\
\text { bottom } \\
\text { (feet) }\end{array}$ & $\begin{array}{c}\text { Construc- } \\
\text { tion } \\
\text { date }\end{array}$ \\
\hline A027 & 574404152300301 & GW & 06D & 24.2 & 4.5 & 2 & -0.5 & 4.5 & 880128 \\
\hline A027-03 & 574404152300301 & SL & 06D & - & - & - & - & - & 880128 \\
\hline A028 & 574403152295601 & GW & 06D & 22.2 & 15.5 & 2 & 10.5 & 15.5 & 880214 \\
\hline A028-05 & 574403152295601 & SL & 06D & - & - & - & - & - & 880214 \\
\hline A029 & 574405152294601 & GW & 09D & 32. & 23. & 2 & 13. & 23. & 880131 \\
\hline A029-05 & 574405152294601 & SL & 09D & - & - & - & - & - & 880131 \\
\hline A030 & 574402152294401 & GW & 09D & 67.1 & 18.5 & 2 & 13.5 & 18.5 & 880130 \\
\hline A030-05 & 574402152294401 & SL & 09D & - & - & - & - & - & 880130 \\
\hline $\mathrm{A} 032$ & 574358152294101 & GW & 09D & 50.9 & 3.5 & 2 & -1.5 & 3.5 & 880129 \\
\hline A032-03 & 574358152294101 & SL & 09D & - & - & - & - & - & 880129 \\
\hline A032A & 574359152294001 & GW & 09D & 53. & 13.5 & 2 & 3.5 & 13.5 & 880415 \\
\hline A032A-03 & 574359152294001 & SL & 09D & - & - & - & - & $\cdot$ & 880415 \\
\hline $\mathrm{A} 033$ & 574400152294901 & GW & 09D & 72.9 & 16. & 2 & 11. & 16. & 880129 \\
\hline A033-05 & 574400152294901 & SL & 09D & - & - & - & - & - & 880129 \\
\hline A034 & 574400152295901 & GW & 06D, 09D & 22.9 & 9. & 2 & 4. & 9. & 880215 \\
\hline A034-05 & 574400152295901 & SL & 06D, 09D & - & - & - & - & - & 880215 \\
\hline A035 & 574400152300301 & GW & 03D, 06D & 22.7 & 18.5 & 2 & 8.5 & 18.5 & 880215 \\
\hline$A 035-05$ & 574400152300301 & SL & 03D, 06D & - & - & - & - & - & 880215 \\
\hline A036 & 574401152300801 & GW & 03D, 06D & 21.9 & 7.5 & 2 & 2.5 & 7.5 & 880214 \\
\hline A036-05 & 574401152300801 & SL & 03D, 06D & - & - & - & - & - & 880214 \\
\hline A037 & 574402152301201 & GW & 03D, 06D & 19.2 & 25. & 2 & 15. & 25. & 880213 \\
\hline A037-10 & 574402152301201 & SL & 03D, 06D & - & - & - & - & - & 880213 \\
\hline A038 & 574358152301001 & GW & 06D & 18.3 & 11. & 2 & 1. & 11. & 880214 \\
\hline A038-05 & 574358152301001 & SL & $06 \mathrm{D}$ & - & - & - & - & - & 880214 \\
\hline A039 & 574359152300701 & GW & 03D & 22.1 & 12. & 2 & 2. & 12. & 880215 \\
\hline A039-04 & 574359152300701 & SL & 03D & - & - & - & - & - & 880215 \\
\hline $\mathrm{A} 040$ & 574358152300601 & GW & 03D & 21.5 & 8. & 2 & 3. & 8. & 880215 \\
\hline
\end{tabular}


Table 2. Location and description of soil and ground-water data-collection sites, U.S. Coast Guard Support Center Kodiak--Continued

[Site type: GW, ground water; SL, soil or lake-bed material; * indicates water elevation only, no water quality data was obtained at the site. Area: D, downgradient; U, upgradient. -, not applicable]

\begin{tabular}{|c|c|c|c|c|c|c|c|c|c|}
\hline Site No. & $\begin{array}{l}\text { USGS Station } \\
\text { number }\end{array}$ & $\begin{array}{l}\text { Site } \\
\text { type }\end{array}$ & Area & $\begin{array}{l}\text { Land- } \\
\text { surface } \\
\text { altitude } \\
\text { (feet) }\end{array}$ & $\begin{array}{l}\text { Well } \\
\text { depth } \\
\text { (feet) }\end{array}$ & $\begin{array}{l}\text { Well } \\
\text { diam- } \\
\text { eter } \\
\text { (inches) }\end{array}$ & $\begin{array}{c}\text { Screen } \\
\text { top } \\
\text { (feet) }\end{array}$ & $\begin{array}{c}\text { Screen } \\
\text { bottom } \\
\text { (feet) }\end{array}$ & $\begin{array}{c}\text { Construc- } \\
\text { tion } \\
\text { date }\end{array}$ \\
\hline A040-05 & 574358152300601 & SL & 03D & - & - & - & - & - & 880215 \\
\hline A041 & 574357152300301 & GW & $\begin{array}{l}\text { 03U, 06D, } \\
\text { 09D }\end{array}$ & 25.6 & 9. & 2 & 4. & 9. & 880215 \\
\hline A041-04 & 574357152300301 & SL & $\begin{array}{l}\text { 03U, 06D, } \\
\text { 09D }\end{array}$ & - & - & - & - & - & 880215 \\
\hline A042 & 574358152302301 & GW & $06 \mathrm{D}, 17 \mathrm{D}$ & 10.8 & 18.5 & 2 & 8.5 & 18.5 & 880206 \\
\hline A042-05 & 574358152302301 & SL & 06D, 17D & - & - & - & - & - & 880206 \\
\hline A043 & 574355152303001 & GW & 06D & 12.5 & 18. & 2 & 8. & 18. & 880205 \\
\hline A043-05 & 574355152303001 & SL & $06 \mathrm{D}$ & - & - & - & - & - & 880205 \\
\hline A044 & 574348152304001 & GW & 06D, 08D & 6.7 & 18.5 & 2 & 8.5 & 18.5 & 880205 \\
\hline A044-05 & 574348152304001 & SL & 06D, 08D & - & - & - & - & - & 880205 \\
\hline A044-20 & 574348152304001 & SL & 06D, 08D & - & - & - & - & - & 880205 \\
\hline A045 & 574342152304301 & GW & $\begin{array}{l}\text { 06D, 07D, } \\
\text { 08D }\end{array}$ & 10.2 & 7. & 2 & 2. & 7. & 880206 \\
\hline A045-05 & 574342152304301 & SL & $\begin{array}{l}\text { 06D, 07D, } \\
\text { 08D }\end{array}$ & - & - & - & - & - & 880206 \\
\hline A046 & 574340152304401 & GW & $\begin{array}{l}\text { 06D, 07D, } \\
\text { 08D }\end{array}$ & 10.9 & 13.5 & 2 & 3. & 13.5 & 880212 \\
\hline A046-05 & 574340152304401 & SL & 06D, 08D & - & - & - & - & - & 880212 \\
\hline A047 & 574339152304401 & GW & 06D & 12.5 & 15. & 2 & 5. & 15. & 880207 \\
\hline A047-05 & 574339152304401 & SL & 06D & - & - & - & - & - & 880207 \\
\hline A048 & 574335152304801 & GW & 06D & 13.7 & 6.5 & 2 & 1.5 & 6.5 & 880206 \\
\hline A049 & 574332152305101 & GW & $06 \mathrm{D}$ & 10. & 7. & 2 & 2. & 7. & 880208 \\
\hline A049-04 & 574332152305101 & SL & 06D & - & - & - & - & - & 880208 \\
\hline A050 & 574331152305601 & GW & $06 \mathrm{D}$ & 8.2 & 12.5 & 2 & 7.5 & 12.5 & 880207 \\
\hline A050-05 & 574331152305601 & SL & 06D & - & - & - & - & - & 880207 \\
\hline A051 & 574327152305501 & GW & 06D & 38.1 & 9.5 & 2 & 4.5 & 9.5 & 880209 \\
\hline A051-03 & 574327152305501 & SL & 06D & - & - & - & - & - & 880209 \\
\hline A052 & 574329152304701 & GW & 06D & 41.9 & 18.5 & 2 & 13.5 & 18.5 & 880209 \\
\hline
\end{tabular}


Table 2. Location and description of soil and ground-water data-collection sites, U.S. Coast Guard Support Center Kodiak--Continued

[Site type: GW, ground water; SL, soil or lake-bed material; * indicates water elevation only, no water quality data was obtained at the site. Area: D, downgradient; U, upgradient. -, not applicable]

\begin{tabular}{|c|c|c|c|c|c|c|c|c|c|}
\hline Site No. & $\begin{array}{l}\text { USGS Station } \\
\text { number }\end{array}$ & $\begin{array}{l}\text { Site } \\
\text { type }\end{array}$ & Area & $\begin{array}{l}\text { Land- } \\
\text { surface } \\
\text { altitude } \\
\text { (feet) }\end{array}$ & $\begin{array}{l}\text { Well } \\
\text { depth } \\
\text { (feet) }\end{array}$ & $\begin{array}{c}\text { Well } \\
\text { diam- } \\
\text { eter } \\
\text { (inches) }\end{array}$ & $\begin{array}{c}\text { Screen } \\
\text { top } \\
\text { (feet) }\end{array}$ & $\begin{array}{c}\text { Screen } \\
\text { bottom } \\
\text { (feet) }\end{array}$ & $\begin{array}{c}\text { Construc- } \\
\text { tion } \\
\text { date }\end{array}$ \\
\hline A052-04 & 574329152304701 & SL & 06D & - & - & - & - & - & 880209 \\
\hline A052-09 & 574329152304701 & SL & 06D & - & - & - & - & - & 880209 \\
\hline A053 & 574329152304301 & GW & 06D & 29.4 & 2.5 & 2 & 0.5 & 2.5 & 880209 \\
\hline A054 & 574330152304001 & GW & 06D & 30.5 & 12. & 2 & 7. & 12. & 880203 \\
\hline A054-SOIL & 574330152304001 & SL & 06D & - & - & - & - & - & 880203 \\
\hline A055 & 574332152303601 & GW & 06D & 25.4 & 15. & 2 & 10. & 15. & 880202 \\
\hline A056 & 574334152303101 & GW & $06 \mathrm{D}$ & 27.8 & 16.5 & 2 & 6.5 & 16.5 & 880202 \\
\hline A056-05 & 574334152303101 & SL & 06D & - & - & - & - & - & 880202 \\
\hline A057 & 574339152303601 & GW & 06D, 07D & 56.7 & 8.5 & 2 & 3.5 & 8.5 & 880210 . \\
\hline A057-09 & 574339152303601 & SL & 06D, 07D & - & - & - & - & - & 880210 \\
\hline A058 & 574340152303801 & GW & 06D, 07D & 52.7 & 10. & 2 & 3. & 8. & 880210 \\
\hline A058-05 & 574340152303801 & SL & 06D, 07D & - & - & - & - & - & 880210 \\
\hline A059 & 574342152303601 & GW & 06D, 07D & 55.6 & 13.5 & 2 & 3.5 & 13.5 & 880210 \\
\hline A059-05 & 574342152303601 & SL & 06D, 07D & - & - & - & - & - & 880210 \\
\hline A060 & 574340152303101 & GW & 06D, 07D & 57.1 & 8.5 & 2 & 1.5 & 6.5 & 880210 \\
\hline A060-05 & 574340152303101 & SL & 06D, 07D & - & - & - & - & - & 880210 \\
\hline A061 & 574344152302601 & GW & 06D, 07D & 66.1 & 17. & 2 & 12. & 17. & 880211 \\
\hline A061-05 & 574344152302601 & SL & 06D, 07D & - & - & - & - & - & 880211 \\
\hline A062 & 574346152302601 & GW & 06D & 61.5 & 10.5 & 2 & 3.5 & 8.5 & 880213 \\
\hline A062-05 & 574346152302601 & SL & 06D & - & - & - & - & - & 880213 \\
\hline A063 & 574348152302301 & GW & 06D & 61.2 & 7.5 & 2 & 2.5 & 7.5 & 880212 \\
\hline A063-04 & 574348152302301 & SL & 06D & - & - & - & - & - & 880212 \\
\hline A064 & 574342152301801 & GW & 06D, 07D & 34. & 19. & 2 & 9. & 19. & 880203 \\
\hline A064-SOIL & 574342152301801 & SL & 06D, 07D & - & - & - & - & - & 880203 \\
\hline $\mathrm{A} 065$ & 574344152301501 & GW & 06D, 07D & 30.7 & 8. & 2 & 3. & 8. & 880201 \\
\hline A065-05 & 574344152301501 & SL & 06D, 07D & - & - & - & - & - & 880201 \\
\hline $\mathrm{A} 066 \mathrm{~A}$ & 574347152302102 & GW & 06D, 07U & 70.2 & 12.5 & 2 & 2.5 & 12.5 & 880211 \\
\hline
\end{tabular}


Table 2. Location and description of soil and ground-water data-collection sites, U.S. Coast Guard Support Center Kodiak--Continued

[Site type: GW, ground water; SL, soil or lake-bed material; * indicates water elevation only, no water quality data was obtained at the site. Area: D, downgradient; U, upgradient. -, not applicable]

\begin{tabular}{|c|c|c|c|c|c|c|c|c|c|}
\hline Site No. & $\begin{array}{l}\text { USGS Station } \\
\text { number }\end{array}$ & $\begin{array}{l}\text { Site } \\
\text { type }\end{array}$ & Area & $\begin{array}{l}\text { Land- } \\
\text { surface } \\
\text { altitude } \\
\text { (feet) }\end{array}$ & $\begin{array}{l}\text { Well } \\
\text { depth } \\
\text { (feet) }\end{array}$ & $\begin{array}{l}\text { Well } \\
\text { diam- } \\
\text { eter } \\
\text { (inches) }\end{array}$ & $\begin{array}{c}\text { Screen } \\
\text { top } \\
\text { (feet) }\end{array}$ & $\begin{array}{c}\text { Screen } \\
\text { bottom } \\
\text { (feet) }\end{array}$ & $\begin{array}{l}\text { Construc- } \\
\text { tion } \\
\text { date }\end{array}$ \\
\hline A066A-04 & 574347152302102 & SL & 06D, 07U & - & - & - & - & - & 880211 \\
\hline A067 & 574349152302001 & GW & 06D & 75. & 12. & 2 & 4. & 9. & 880211 \\
\hline A067-04 & 574349152302001 & SL & 06D & - & - & - & - & - & 880211 \\
\hline $\mathrm{A} 068 \mathrm{~A}$ & 574351152301501 & GW & $06 \mathrm{U}$ & 82.6 & 15. & 2 & 5. & 15. & 880413 \\
\hline A068A-05 & 574351152301501 & SL & $06 \mathrm{U}$ & - & - & - & - & - & 880413 \\
\hline A069 & 574345152301901 & GW & 06D, 07D & 60.5 & 9. & 2 & 2. & 7. & 880212 \\
\hline A069-05 & 574345152301901 & SL & 06D, 07D & - & - & - & - & - & 880212 \\
\hline $\mathrm{A} 070$ & 574348152301001 & GW & 06D & 51.2 & 19. & 2 & 9. & 19. & 880204 \\
\hline A070-18 & 574348152301001 & SL & 06D & - & - & - & - & - & 880204 \\
\hline A071 & 574349152300501 & GW & 09D & 61.5 & 18.5 & 2 & 8.5 & 18.5 & 880204 \\
\hline A071-SOIL & 574349152300501 & SL & 09D & - & - & - & - & - & 880204 \\
\hline $\mathrm{A} 072$ & 574352152300101 & GW & 09D & 83.6 & 3. & 2 & -2 & 3. & 880205 \\
\hline A073 & 574348152300101 & GW & 09D & 58.9 & 28. & 2 & 23. & 28. & 880201 \\
\hline A073-05 & 574348152300101 & SL & 09D & - & - & - & - & - & 880201 \\
\hline A074 & 574319152311501 & $\mathrm{GW}^{*}$ & 06D & 27.3 & 4.5 & 2 & -0.5 & 4.5 & 880128 \\
\hline A074-05 & 574319152311501 & SL & $06 \mathrm{D}$ & - & - & - & - & - & 880128 \\
\hline A075 & 574318152311101 & GW & $06 \mathrm{D}$ & 14.3 & 10 & 2 & 5. & 10. & 880128 \\
\hline A075-05 & 574318152311101 & SL & 06D & - & - & - & - & - & 880128 \\
\hline A076 & 574351152301801 & $\mathrm{GW}^{*}$ & 06D & 67.8 & 6.5 & 2 & 1.5 & 6.5 & 880212 \\
\hline A076-05 & 574351152301801 & SL & 06D & - & - & - & - & - & 880212 \\
\hline A077 & 574531152304901 & GW & 14D & 29.5 & 23.5 & 2 & 8.5 & 23.5 & 880419 \\
\hline A077-05 & 574531152304901 & SL & 14D & - & - & - & - & - & 880419 \\
\hline A078 & 574552152304701 & GW & $02 \mathrm{U}$ & 83.1 & 8.5 & 2 & 3.5 & 8.5 & 880419 \\
\hline A078-05 & 574552152304701 & SL & $02 \mathrm{U}$ & - & - & - & - & - & 880419 \\
\hline A079 & 574513152303101 & GW & $16 \mathrm{D}$ & 56.6 & 19. & 2 & 9. & 19. & 880418 \\
\hline A079-05 & 574513152303101 & SL & $16 \mathrm{D}$ & - & - & - & - & - & 880418 \\
\hline A081 & 574443152300301 & GW & $18 \mathrm{D}$ & 68.1 & 18. & 2 & 3. & 18. & 880421 \\
\hline
\end{tabular}


Table 2. Location and description of soil and ground-water data-collection sites, U.S. Coast Guard Support Center Kodiak--Continued

[Site type: GW, ground water; SL, soil or lake-bed material; * indicates water elevation only, no water quality data was obtained at the site. Area: D, downgradient; U, upgradient. -, not applicable]

\begin{tabular}{|c|c|c|c|c|c|c|c|c|c|}
\hline Site No. & $\begin{array}{l}\text { USGS Station } \\
\text { number }\end{array}$ & $\begin{array}{l}\text { Site } \\
\text { type }\end{array}$ & Area & $\begin{array}{l}\text { Land- } \\
\text { surface } \\
\text { altitude } \\
\text { (feet) }\end{array}$ & $\begin{array}{l}\text { Well } \\
\text { depth } \\
\text { (feet) }\end{array}$ & $\begin{array}{c}\text { Well } \\
\text { diam- } \\
\text { eter } \\
\text { (inches) }\end{array}$ & $\begin{array}{c}\text { Screen } \\
\text { top } \\
\text { (feet) }\end{array}$ & $\begin{array}{c}\text { Screen } \\
\text { bottom } \\
\text { (feet) }\end{array}$ & $\begin{array}{c}\text { Construc- } \\
\text { tion } \\
\text { date }\end{array}$ \\
\hline A081-05 & 574443152300301 & SL & $18 \mathrm{D}$ & - & - & - & - & - & 880421 \\
\hline A082 & 574457152293801 & GW & $15 \mathrm{D}$ & 39.4 & 30.5 & 2 & 10.5 & 30.5 & 880420 \\
\hline A082-05 & 574457152293801 & SL & $15 \mathrm{D}$ & - & - & - & - & - & 880420 \\
\hline A084 & 574344152303401 & GW & $\begin{array}{l}\text { 06D, 07D, } \\
08 \mathrm{U}\end{array}$ & 45.9 & 13.5 & 2 & 3.5 & 13.5 & 880414 \\
\hline A084-05 & 574344152303401 & SE & $\begin{array}{l}\text { 06D, 07D, } \\
08 \mathrm{U}\end{array}$ & - & - & - & - & - & 880414 \\
\hline A085 & 574347152302801 & GW & 06D & 49.1 & 19. & 2 & 9. & 19. & 880413 \\
\hline A085-05 & 574347152302801 & SL & 06D & - & - & - & - & - & 880413 \\
\hline A086 & 574358152301701 & GW & 06D, 17D & 7.3 & 12. & 2 & 2. & 12. & 880417 \\
\hline A086-05 & 574358152301701 & SL & 06D, 17D & - & - & - & - & - & 880417 \\
\hline B001 & 574447152285901 & GW & $05 \mathrm{D}, 16 \mathrm{D}$ & 37.7 & 40. & 2 & 30. & 40. & 890516 \\
\hline B001-00 & 574447152285901 & SL & 05D, 16D & - & - & - & - & - & 890516 \\
\hline B002 & 574444152290302 & GW & 05D, 16D & 38.4 & 40. & 2 & 30. & 40. & 890513 \\
\hline B002-05.5 & 574444152290302 & SL & 05D, 16D & - & - & - & - & - & 890513 \\
\hline B002-09.5 & 574444152290302 & SL & 05D, 16D & - & - & - & - & - & 890513 \\
\hline B002-14 & 574444152290302 & SL & 05D, 16D & - & - & - & - & - & 890513 \\
\hline B002-34 & 574444152290302 & SL & $05 \mathrm{D}, 16 \mathrm{D}$ & - & - & - & - & - & 890513 \\
\hline B003 & 574444152290701 & GW & 05D, 16D & 28.4 & 32.5 & 2 & 22.5 & 32.5 & 890516 \\
\hline B003-03.5 & 574444152290701 & SL & 05D, 16D & - & - & - & - & - & 890516 \\
\hline B003-13.5 & 574444152290701 & SL & 05D, 16D & - & - & - & - & - & 890516 \\
\hline B003-20 & 574444152290701 & SL & 05D, 16D & - & - & - & - & - & 890516 \\
\hline B004 & 574401152300601 & GW & 03D & 21.9 & 22.5 & 2 & 12.5 & 22.5 & 890514 \\
\hline B004-03 & 574401152300601 & SL & 03D & - & - & - & - & - & 890514 \\
\hline B005 & 574359152300501 & GW & 03D & 25.1 & 20.5 & 2 & 10.5 & 20.5 & 890515 \\
\hline B005-03.5 & 574359152300501 & SL & 03D & - & - & - & - & - & 890515 \\
\hline B006 & 574359152300702 & GW & 03D & 21.5 & 30. & 2 & 20. & 30. & 890514 \\
\hline B006-03.5 & 574359152300702 & SL & 03D & - & - & - & - & - & 890514 \\
\hline
\end{tabular}


Table 2. Location and description of soil and ground-water data-collection sites, U.S. Coast Guard Support Center Kodiak--Continued

[Site type: GW, ground water; SL, soil or lake-bed material; * indicates water elevation only, no water quality data was obtained at the site. Area: D, downgradient; U, upgradient. -, not applicable]

\begin{tabular}{|c|c|c|c|c|c|c|c|c|c|}
\hline Site No. & $\begin{array}{l}\text { USGS Station } \\
\text { number }\end{array}$ & $\begin{array}{l}\text { Site } \\
\text { type }\end{array}$ & Area & $\begin{array}{l}\text { Land- } \\
\text { surface } \\
\text { altitude } \\
\text { (feet) }\end{array}$ & $\begin{array}{l}\text { Well } \\
\text { depth } \\
\text { (feet) }\end{array}$ & $\begin{array}{l}\text { Well } \\
\text { diam- } \\
\text { eter } \\
\text { (inches) }\end{array}$ & $\begin{array}{c}\text { Screen } \\
\text { top } \\
\text { (feet) }\end{array}$ & $\begin{array}{c}\text { Screen } \\
\text { bottom } \\
\text { (feet) }\end{array}$ & $\begin{array}{l}\text { Construc- } \\
\text { tion } \\
\text { date }\end{array}$ \\
\hline B006-06 & 574359152300702 & SL & 03D & - & - & - & - & - & 890514 \\
\hline B006-22 & 574359152300702 & SL & 03D & - & - & - & - & - & 890514 \\
\hline B007 & 574354152301401 & GW & 06D, 17D & 52.6 & 7.5 & 2 & 2.5 & 7.5 & 890518 \\
\hline B007-00.5 & 574354152301401 & SL & 06D, 17D & - & - & - & - & - & 890518 \\
\hline B007-03 & 574354152301401 & SL & 06D, 17D & - & - & - & - & - & 890518 \\
\hline B008 & 574344152303402 & GW & 07D & 55.6 & 9. & 2 & 4. & 9. & 890519 \\
\hline B008-03 & 574344152303402 & SL & 07D & - & - & - & - & - & 890519 \\
\hline B008-07 & 574344152303402 & SL & 07D & - & - & - & - & - & 890519 \\
\hline В009-00.5 & 574342152303401 & SL & 07D & - & - & - & - & - & 890519 \\
\hline В009-03 & 574342152303401 & SL & 07D & - & - & - & - & - & 890519 \\
\hline В009-07 & 574342152303401 & SL & 07D & - & - & - & - & - & 890519 \\
\hline B010 & 574342152303501 & GW & 06D, 07D & 56. & 14. & 2 & 4. & 14. & 890518 \\
\hline B010-03 & 574342152303501 & SL & 06D, 07D & - & - & - & - & - & 890518 \\
\hline B010-07 & 574342152303501 & SL & 06D, 07D & - & - & - & - & - & 890518 \\
\hline B011 & 574322152310601 & GW & 06D & 39.6 & 11.5 & 2 & 1.5 & 11.5 & 890517 \\
\hline B011-04 & 574322152310601 & SL & 06D & - & - & - & - & - & 890517 \\
\hline B011-07 & 574322152310601 & SL & 06D & - & - & - & - & - & 890517 \\
\hline B012 & 574322152310801 & GW & 06D & 27.5 & 22. & 2 & 12. & 22. & 890517 \\
\hline B012-02 & 574322152310801 & SL & 06D & - & - & - & - & - & 890517 \\
\hline B012-07 & 574322152310801 & SL & 06D & - & - & - & - & - & 890517 \\
\hline B012-12 & 574322152310801 & SL & 06D & - & - & - & - & - & 890517 \\
\hline B013-00 & 574446152290101 & SL & 05D & - & - & - & - & - & - \\
\hline B014-02 & 574446152290102 & SL & 05D & - & - & - & - & - & - \\
\hline CG 1 & 574608152303701 & GW & 01D & 45.1 & 23 & 6 & - & - & 860805 \\
\hline CG 2 & 574557152302601 & GW & 01D & 58. & 7 & 6 & - & - & 860805 \\
\hline CG 3 & 574603152301701 & GW & 01D & 77. & 6.5 & 6 & - & - & 860805 \\
\hline CG 4 & 574534152284401 & GW & $19 U$ & 36. & 115. & 6 & - & - & 41---- \\
\hline
\end{tabular}


Four wells (CG 1 to CG 4) were drilled by the USCG before this study and were constructed using steel casing. The USGS constructed 97 additional wells that yielded sufficient water for water-quality sampling. The lithology penetrated by and the construction of each well are described by Carr (1996). Each well constructed by the USGS used threaded polyvinyl chloride (PVC) casing and screens, a bentonite seal in the wellbore annulus, and a concrete surface pad. Ground-water levels in wells drilled by the USGS were generally measured monthly and before each water-quality sampling. Water samples from selected wells were collected during May, July, and October 1988, and March and May 1989.

Water samples were also collected from 59 sites on streams, lakes, or ponds. Surface-water samples were collected from selected sites during July 1987, May and July 1988, and February 1989. Solin (1996) discusses the flows observed in the Center's streams, and estimates peak-, average-, and low-flow values for Buskin River.

Samples of water from the drinking-water distribution system were also collected from a water-treatment plant near Buskin Lake (TW 1) on July 25, 1988 and from a hotel north of the airport (TW 2) on July 25, 1988 and February 23, 1989. The source of the treated-water samples was Buskin Lake, and the samples were collected after the water had been chlorinated.

\section{Sampling Protocols and Analytical Methods}

Four types of chemical analysis schemes or protocols were used as general guides for initial soil- and water-quality monitoring. The methods used to analyze soil and water samples and the most commonly used reporting levels for each analytical method are described in appendix 1 and in the following references: American Public Health Association and others $(1980,1985)$ for analytical methods prefixed with "A"; U.S. Environmental Protection Agency (USEPA) $(1979,1987)$ and Federal Register, Vol. 49, No. 209, October 26, 1984 for methods starting with "E"; American Society for Testing and Materials $(1964,1966,1978)$ for methods starting with "D"; and USEPA (1986) for methods starting with "SW".

The analyses and methods generally used for sites in Areas 3-10, 12, and 14-16, where fuels may have been spilled, were:

\begin{tabular}{lll}
\hline & \multicolumn{2}{c}{ Analytical method } \\
\cline { 2 - 3 } Property or chemical constituent & Water & Soil \\
Temperature (field test) & E170.1 & -- \\
Specific conductance (field test) & E120.1 & -- \\
pH (field test) & E150.1 & -- \\
Total solids & -- & D2216 \\
Lead & E239.2 & SW7421 \\
Total petroleum hydrocarbons & E418.1 & E418.1 \\
Aromatic volatile organics & E602 & SW8020 \\
1,2-Dibromoethane & E502.1 & -- \\
\hline
\end{tabular}

In addition to the above analyses, surfactants (method E425.1) and halogenated volatile organic compounds (method E601) were measured in Areas 3 and 5, respectively.

In landfill and storage-pad areas (Areas 1,2,17, and 18), where a variety of substances may cause contamination, the following protocol was generally used: 


\begin{tabular}{llc}
\hline & \multicolumn{2}{c}{ Analytical method } \\
Property or chemical constituent & Water & Soil \\
Temperature (field test) & E170.1 & -- \\
Specific conductance (field test) & E120.1 & -- \\
pH (field test) & E150.1 & -- \\
Total solids & -- & D2216 \\
Common anions & A429 & -- \\
Metals & E200.7 & -- \\
Arsenic & E206.2 & -- \\
Mercury & E245.1 & -- \\
Selenium & E270.2 & -- \\
Total dissolved solids & E160.1 & -- \\
Total petroleum hydrocarbons & E418.1 & E418.1 \\
Purgeable halocarbons & E601 & SW8010 \\
Aromatic volatile organics & E602 & SW8020 \\
Extractable priority pollutants & E625 & -- \\
\hline
\end{tabular}

Dioxins and furans also were analyzed using method SW8280 in Area 18 where polychlorinated biphenyls (PCB's) were suspected.

Bed-material samples from Peninsula Lake (Area 6) and Red Lake (Area 2) were analyzed using the following methods:

\begin{tabular}{lc}
\hline & Analytical method \\
Property or chemical constituent & for bed material \\
Total solids & D2216 \\
Metals & E200.7 \\
Lead & SW7421 \\
Purgeable halocarbons & SW8010 \\
Aromatic volatile organics & SW8020 \\
Extractable priority pollutants & E625 \\
\hline
\end{tabular}

In areas not expected to be contaminated (Area 19) soil samples were generally not collected or analyzed. The following protocol was commonly used to characterize water quality:

\begin{tabular}{lr}
\hline & $\begin{array}{c}\text { Analytical method } \\
\text { Rroperty or chemical constituent }\end{array}$ \\
Temperature (field test) & E170.1 \\
Specific conductance (field test) & $\mathrm{E} 120.1$ \\
pH (field test) & $\mathrm{E} 150.1$ \\
Alkalinity, carbonate and bicarbonate & $\mathrm{A} 403$ \\
Common anions & $\mathrm{A} 429$ \\
Total dissolved solids & $\mathrm{E} 160.1$ \\
Metals & $\mathrm{E} 200.7$ \\
Arsenic & $\mathrm{E} 206.2$ \\
Mercury & $\mathrm{E} 245.1$ \\
Selenium & $\mathrm{E} 270.2$ \\
Purgeable halocarbons & $\mathrm{E} 601$ \\
\hline
\end{tabular}

Analytical results were reviewed after each sampling round and future analytical methods were modified as seemed appropriate to meet program objectives. No wells were drilled in Areas 11 and 13 because surveys made using an organic vapor analyzer found that readings in air and in soils were at background levels; thus no ground-water samples were analyzed.

\section{Sample Collection}

Before each soil or water sample was collected, all sampling equipment was disassembled and thoroughly cleaned. Each pressure-plate filter apparatus used during the collection of inorganic water samples was washed using non-phosphate detergent, rinsed with 5 percent hydrochloric acid, 
and rinsed again with organic-free de-ionized water. Teflon bailers used to collect ground-water samples for both organic and inorganic analyses were washed with non-phosphate detergent and rinsed with tap water, methanol, hexane, and organic-free de-ionized water.

Information about the collection of each soil- and water-quality sample was recorded in field log-books. Chain-of-custody records were made to document sample handling from the time of collection until analysis.

The annotation used to describe each soil sample is based upon the sample's site number and the depth at which sampling started. For example, sample "A006A-05" indicates that the sample was obtained $5 \mathrm{ft}$ below land surface at site A006A. However, where it was not possible to determine precise sampling depth, the sample number does not include a depth value, but includes the suffix "SOIL" instead. Most soil samples were collected between 3 and $10 \mathrm{ft}$ below land surface and were typically less than $3 \mathrm{ft}$ above or below the water table. Soil samples obtained at depths less than $3 \mathrm{ft}$ were collected using a shovel and a stainless steel trowel. Soil samples from depths of $3 \mathrm{ft}$ or more were collected with a split-spoon sampler. Samples of lake-bottom sediments were recovered from Red Lake and Peninsula Lake using an Ekman dredge. Soil samples were examined in the field to determine physical characteristics such as grain size, sorting, color, and saturation. A total of 110 samples underwent laboratory analyses to determine moisture and solid content and to identify and quantify concentrations of selected volatile organic constituents and lead.

A static water-level measurement was made at each well using a steel or electric tape. A transparent teflon bailer was used to allow visual observation of any film of immiscible compounds floating on the water surface within each well. Thin films were detected at wells A021A and A069. Low-yield wells were fully purged at least once before sampling using a peristaltic pump and silicon tubing or a teflon bailer. At least three casing-volumes were evacuated from higher yielding wells before sampling with a teflon bailer equipped with double check valves. Each bailer had a bottom-emptying device to allow the sample containers to be filled with a minimum of sample disturbance. A new nylon monofilament line was used to raise and lower the bailer in each well. Bailers were raised and lowered slowly to prevent degassing of water in the well. Temperature, $\mathrm{pH}$, and specific conductance of the water were measured as the water was bailed or pumped from the well. Field equipment used for measuring $\mathrm{pH}$ and specific conductance was calibrated daily and recalibrated periodically throughout each day. Higher yielding wells were considered successfully purged when the discharge water chemically stabilized with regard to temperature, $\mathrm{pH}$, and specific conductance. The reported values of temperature, $\mathrm{pH}$, and specific conductance were the last values recorded before the collection of water samples for laboratory analyses. Ground-water samples were transferred from bailers directly into appropriate containers.

Polyethylene containers with polyethylene-lined caps were used to store water samples for chemical analyses of metals, whereas sample containers for organic chemicals were glass bottles with fluorocarbon resin-lined caps. Samples collected for volatile organics analysis were stored in glass gas-chromatograph vials with septum tops which were filled until no head space remained; concentrated hydrochloric acid was added to each sample to lower its $\mathrm{pH}$ to less than $2 \mathrm{pH}$ units. Samples $(250 \mathrm{~mL})$ for dissolved metals were filtered using a 0.45 -micron filter and preserved with $1 \mathrm{~mL}$ of nitric acid to a $\mathrm{pH}$ of $<2 \mathrm{pH}$ units. All samples were placed in iced coolers and shipped daily for next-day delivery to the laboratory. Water samples collected before February 1988 were analyzed by a USGS laboratory; samples collected after February 1988 were analyzed by EnsecoRocky Mountain Analytical Laboratory under USGS contract. 
Surface-water samples were collected from selected sites during each sampling period. Water temperature, $\mathrm{pH}$, and specific conductance were determined at each site using calibrated instruments. Surface-water-quality samples for volatile organic analysis were collected from streams by dipping gas-chromatograph vials beneath the water surface and then acidifying the sample with concentrated hydrochloric acid. Surface-water samples to be analyzed for inorganic constituents were collected using a peristaltic pump with silicon tubing and were pumped into polyethylene containers. Samples $(250 \mathrm{~mL})$ for dissolved metals were filtered using a 0.45 -micron filter and preserved with $1 \mathrm{~mL}$ of nitric acid to a $\mathrm{pH}$ of $<2 \mathrm{pH}$ units. However, surface-water samples collected for metal analyses during July, August, and October 1987 were unfiltered. Stream discharge was also measured after the water samples were collected.

Water samples from Buskin Lake (surface-water sites 4 and 6 ) were collected using a brass van Doren bottle. Water depth at site 4 was $56 \mathrm{ft}$, and the water sample was collected $30 \mathrm{ft}$ below the water surface. The water depth at site 6 was $42 \mathrm{ft}$, and the sample was collected $20 \mathrm{ft}$ below the surface.

\section{Quality Assurance}

Several methods were used to assure that the reported analytical results accurately express the ambient constituent concentrations in the water being sampled. Accuracy was monitored by the use of spiked samples (samples with known concentrations of a constituent are submitted to the laboratory). Precision was monitored by submitting differently labeled duplicates of some samples so the laboratory would not know the samples were duplicates. Results from duplicate soil, groundwater, and surface-water samples are included in appendixes 2,3 , and 4. Field blanks were submitted and analyzed to monitor potential sample contamination by collection, transport, storage, and analytical procedures. A trip blank and an equipment blank were prepared each sampling day and an ambient-conditions blank was prepared on the first day of each sampling trip and submitted to the lab with the last set of samples from that trip. Preparation of trip blanks and ambient-conditions blanks is done by filling glass gas-chromatograph vials with organic-free de-ionized ("blank") water, transporting them to sites, handling them like samples, and sending them to the laboratory for analysis. An equipment blank is a sample of de-ionized water that has been poured through the sampling-collection devices to check the adequacy of the cleaning procedures used to clean the sampling equipment. The results from 5 ambient-condition blanks, 24 equipment blanks, and 39 trip blanks are not tabulated in this report but are summarized below. A complete listing of the quality-assurance results is available upon request from the District Chief at the address at the front of this report.

\begin{tabular}{lrr}
\hline \multicolumn{1}{c}{$\begin{array}{c}\text { Analysis } \\
\text { type }\end{array}$} & $\begin{array}{c}\text { Number of } \\
\text { constituents } \\
\text { analyzed }\end{array}$ & $\begin{array}{c}\text { Number of } \\
\text { constituents } \\
\text { detected }\end{array}$ \\
\hline Anions & 66 & 5 \\
Metals and elements & 330 & 13 \\
Organic constituents & 2638 & 46 \\
Surfactants, MBAS & 2 & 0 \\
Total dissolved solids & 7 & 1 \\
Total petroleum hydrocarbons & 17 & 66 \\
Total & -3060 & 1 \\
\hline
\end{tabular}


Anions detected in these quality-control samples were chloride (1.2 and $1.3 \mathrm{mg} / \mathrm{L})$, nitrate $(0.5 \mathrm{mg} / \mathrm{L}$ as $\mathrm{N})$, and bicarbonate $(14 \mathrm{mg} / \mathrm{L}$ total alkalinity and $14 \mathrm{mg} / \mathrm{L}$ bicarbonate). Metals and elements detected were sodium (in 9 blanks from $0.06-1.1 \mathrm{mg} / \mathrm{L}$ ), zinc (in 2 blanks at $0.01 \mathrm{mg} / \mathrm{L}$ ), lead $(0.005 \mathrm{mg} / \mathrm{L})$, and mercury $(0.0001 \mathrm{mg} / \mathrm{L})$. Organic constituents detected in these quality-control samples were methylene chloride ( 2.1 to $5.9 \mu \mathrm{g} / \mathrm{L}$ in 26 blanks); 1,2-dichloroethane (0.33 to $2.6 \mu \mathrm{g} / \mathrm{L}$ in 15 blanks); trichlorofluoromethane $(6.8$ and $8.1 \mu \mathrm{g} / \mathrm{L})$; acetone $(60 \mu \mathrm{g} / \mathrm{L}) ; 1,1,1$ trichloroethane $(0.62 \mu \mathrm{g} / \mathrm{L})$; toluene $(1.5 \mu \mathrm{g} / \mathrm{L})$; and total petroleum hydrocarbons (TPH) $(0.9 \mathrm{mg} / \mathrm{L})$. Methylene chloride and 1,2-dichloroethane are contaminants commonly found in blanks from other projects and may be due to sampling or residual laboratory contamination.

The USGS and the contract laboratory also used blanks, spikes, and standards to assure a high level of quality assurance and quality control (Enseco, 1988). The results of the analyses of field and laboratory blanks and spikes were not used to adjust the water-quality data listed and analyzed in this report.

\section{Data Analysis}

The soil- and water-quality analytical data compiled as a result of this study are contained in the appendixes which are on the disks included with this report. In this report, a Chemical Abstract Service (CAS) number is assigned to each water property or constituent. A CAS number is a unique identifier assigned by the American Chemical Society to chemicals recorded in the Chemical Abstracts Service Registry system. This number can be used to access many chemical databases and to conclusively identify a substance regardless of name.The format of a CAS number is typically $\mathrm{XXX}-\mathrm{XX}-\mathrm{X}$, but the dashes are omitted in this report (71-43-2 is reported as 71432).

For this report, water-quality field properties were assigned arbitrary CAS numbers so that the field properties could also be listed in tables in a format similar to that used to list chemical constituents. In this report, CAS numbers less than 1000 represent field properties, not chemicals. Common field properties and their arbitrary CAS numbers assigned for this investigation are:

\begin{tabular}{lc}
\hline \multicolumn{1}{c}{ Field properties } & $\begin{array}{c}\text { Arbitrary } \\
\text { CAS number }\end{array}$ \\
\hline Water temperature & 10 \\
Instantaneous discharge (streamflow) & 61 \\
Specific conductance & 95 \\
Ground-water level & 237 \\
Dissolved oxygen & 300 \\
pH & 400 \\
\hline
\end{tabular}

For this report, the analytical reporting level is the lower limit of the range in which a concentration can be accurately quantified by the analytical instrument or method employed. Some constituents have more than one reporting level because analytical methods or sample treatment may have been modified during the course of the program. Concentrations of several organic compounds having distinct gas-chromatograph signatures were also analyzed and are listed as TID (tentatively identified) Compounds 1 through 20. 
The reported concentrations of organic chemicals are from the analyses of total (unfiltered) samples. The reported concentrations of inorganic chemicals are from total samples and dissolved (filtered) samples. Results of total and dissolved inorganic analyses are reported separately-concentrations of total inorganic constituents (surface-water samples collected during July, August, and October 1987) are listed in appendix 4 without a CAS number whereas the concentrations of dissolved inorganic constituents are listed with a CAS number.

Before 1989, laboratories reported a single analytical result for each constituent analyzed by each method. In 1989, however, organic analytical results were reported for each gas chromatograph column through which the sample passed. Where two or more concentration values were reported for a chemical constituent, the value noted by the laboratory as the preferred value was used in this report. If the laboratory did not identify a preferred value, the value associated with the lowest reporting level was used in this report. When a constituent was analyzed by more than one method, the value associated with the lowest reporting level was used.

The concentration values for most organic chemical constituents were lower than the levels of analytical detection and these values are reported as being lower than the reporting level for the analytical method used. Methods used to analyze a constituent may not have been the same for each sampling round; thus, reporting level values may be different for each sampling round.

\section{SOIL AND LAKE-BED DATA}

\section{Laboratory Analyses}

Results of laboratory analyses performed on two lake-bed samples and more than 100 soil samples are listed in appendix 2 . Lead is widely dispersed in sedimentary rocks and commonly ranges from 15 to $25 \mathrm{mg} / \mathrm{kg}$ in soils. Concentrations of lead from 107 soil and 2 lake-bed samples ranged from $0.3 \mathrm{mg} / \mathrm{kg}$ (A001-00.5) to $100 \mathrm{mg} / \mathrm{kg}$ (B013-00). The average concentration of lead was $10.6 \mathrm{mg} / \mathrm{kg}$ and the median concentration was $9.8 \mathrm{mg} / \mathrm{kg}$. Total Petroleum Hydrocarbons (TPH) were detected in 19 of 107 soil samples; however, some of the soils at these sites may have naturally occurring organic compounds that result in detectable levels of TPH when analytical method E418.1 is used. Organic constituents detected in soils include: vinyl chloride (A040-05), methylene chloride (A057-09), trichloroethene (A073-05), m-xylene (A069-05), toluene (A069-05 and B013-00), tetrachloroethene (A073-05, B005-03.5, B006-03.5, B006-06, B006-22), and o- \& p-xylenes (A032A-03, A069-05, B009-00.5).

\section{Comparisons with State Guidelines}

Interim contaminated soil cleanup guidelines (Alaska Department of Environmental Conservation (ADEC), 1990) identify soil cleanup target levels for the remediation of gasoline and nongasoline hydrocarbon releases.

Chemical constituents having soil cleanup target levels are listed below. Also noted are sites having a concentration equal to or greater than the proposed cleanup target levels for a gasoline release. 
Proposed cleanup target levels

\begin{tabular}{|c|c|c|c|c|}
\hline Constituent & $\begin{array}{l}\text { CASS } \\
\text { number }\end{array}$ & $\begin{array}{l}\text { Gaso- } \\
\text { line } \\
(\mathrm{mg} / \mathrm{kg})\end{array}$ & $\begin{array}{l}\text { Non- } \\
\text { gaso- } \\
\text { line } \\
(\mathrm{mg} / \mathrm{kg})\end{array}$ & $\begin{array}{l}\text { Sites having a concentration } \\
\text { equal to or exceeding } \\
\text { cleanup target level for } \\
\text { for a gasoline release }\end{array}$ \\
\hline $\begin{array}{l}\text { Total } \\
\text { petroleum } \\
\text { hydrocarbons }\end{array}$ & 5289290400 & 10 & 100 & $\begin{array}{l}\text { The following had concentrations }>50 \mathrm{mg} / \mathrm{kg} \\
\text { A001-00.5, A021-09, A029-05, A034-05, A040-05, } \\
\text { A042-05, A044-05, A054-SOIL, A069-05, B006-06, } \\
\text { B009-00.5, B009-03, B010-03, B012-02, B013-00, } \\
\text { B014-02 }\end{array}$ \\
\hline $\begin{array}{l}\text { Benzene } \\
\text { Total BTEX } \\
\text { Benzene } \\
\text { Toluene }\end{array}$ & $\begin{array}{c}71432 \\
-- \\
71432 \\
108883\end{array}$ & $\begin{array}{l}0.5 \\
1.0\end{array}$ & $\begin{array}{l}\mathrm{N} / \mathrm{A} \\
\mathrm{N} / \mathrm{A}\end{array}$ & $\begin{array}{l}\text { All samples had concentrations }<0.2 \mathrm{mg} / \mathrm{kg} \\
\text { A069-05 } \\
\text { Al1 samples had concentrations }<0.2 \mathrm{mg} / \mathrm{kg} \\
\text { Detected at A069-05 }(0.67 \mathrm{mg} / \mathrm{kg}) \text { and B013-00 } \\
(0.28 \mathrm{mg} / \mathrm{kg})\end{array}$ \\
\hline $\begin{array}{l}\text { Ethylbenzene } \\
\text { Xylenes }\end{array}$ & $\begin{array}{r}100414 \\
1330207\end{array}$ & & & $\begin{array}{l}\text { All samples had concentrations }<0.2 \mathrm{mg} / \mathrm{kg} \\
\text { M-xylene was detected } \\
\text { at A069-05 }(0.28 \mathrm{mg} / \mathrm{kg}) \text { and o- \& p-xylenes } \\
\text { were detected at A032A }(0.3 \mathrm{mg} / \mathrm{kg}) \text {. } \\
\text { A069-05 }(0.34 \mathrm{mg} / \mathrm{kg}) \text { and B009-00.5 (0.29 mg/kg) }\end{array}$ \\
\hline
\end{tabular}

The analytical reporting level for TPH for this study was $50 \mathrm{mg} / \mathrm{kg}$. Therefore, sites listed above have concentrations greater than $50 \mathrm{mg} / \mathrm{kg}$, but it is not known how many or which sites have TPH concentrations between 10 and $50 \mathrm{mg} / \mathrm{kg}$. No soil samples had concentrations of benzene or ethylbenzene greater than analytical reporting levels.

\section{WATER DATA}

Results from the measurements of temperature, specific conductance, and $\mathrm{pH}$ made in the field and the concentrations of organic and inorganic chemicals determined from laboratory analyses are listed for ground water in appendix 3 and for surface water in appendix 4. Measurements of ground-water levels (appendix 5), streamflow measurements (appendix 6), and surface-water elevations (appendix 7) were made to help determine general hydrologic conditions at the Center during the sampling periods. Data collected by the USGS at surface-water sites before February 1987 (when this study was initiated) are also included in appendixes 4, 6, and 7.

\section{Field Analyses}

\section{Temperature}

A total of 347 ground-water and 144 surface-water temperature readings were recorded in the study area. The average temperature of ground water $\left(6.3^{\circ} \mathrm{C}\right)$ was cooler and less variable than was that of surface water $\left(8.9^{\circ} \mathrm{C}\right)$. Water in most small streams and several wells froze during winter. However, underground steam pipes on Nyman Peninsula may maintain above-freezing water temperatures in nearby wells throughout the year.

\section{Specific Conductance}

Specific conductance is an indirect measure of the total concentration of ions dissolved in water. Specific conductance measures the ability of a cubic centimeter of water at $25^{\circ} \mathrm{C}$ to conduct an electric current and is expressed as microsiemens per centimeter $(\mu \mathrm{S} / \mathrm{cm})$. A total of 349 specific conductance observations were recorded from ground-water sites and 155 specific conductance readings were collected at 58 surface-water sites. The mean values of ground-water and surfacewater specific conductance values are summarized below. 
Comparisons of specific conductance for ground water and surface water

(--, no data)

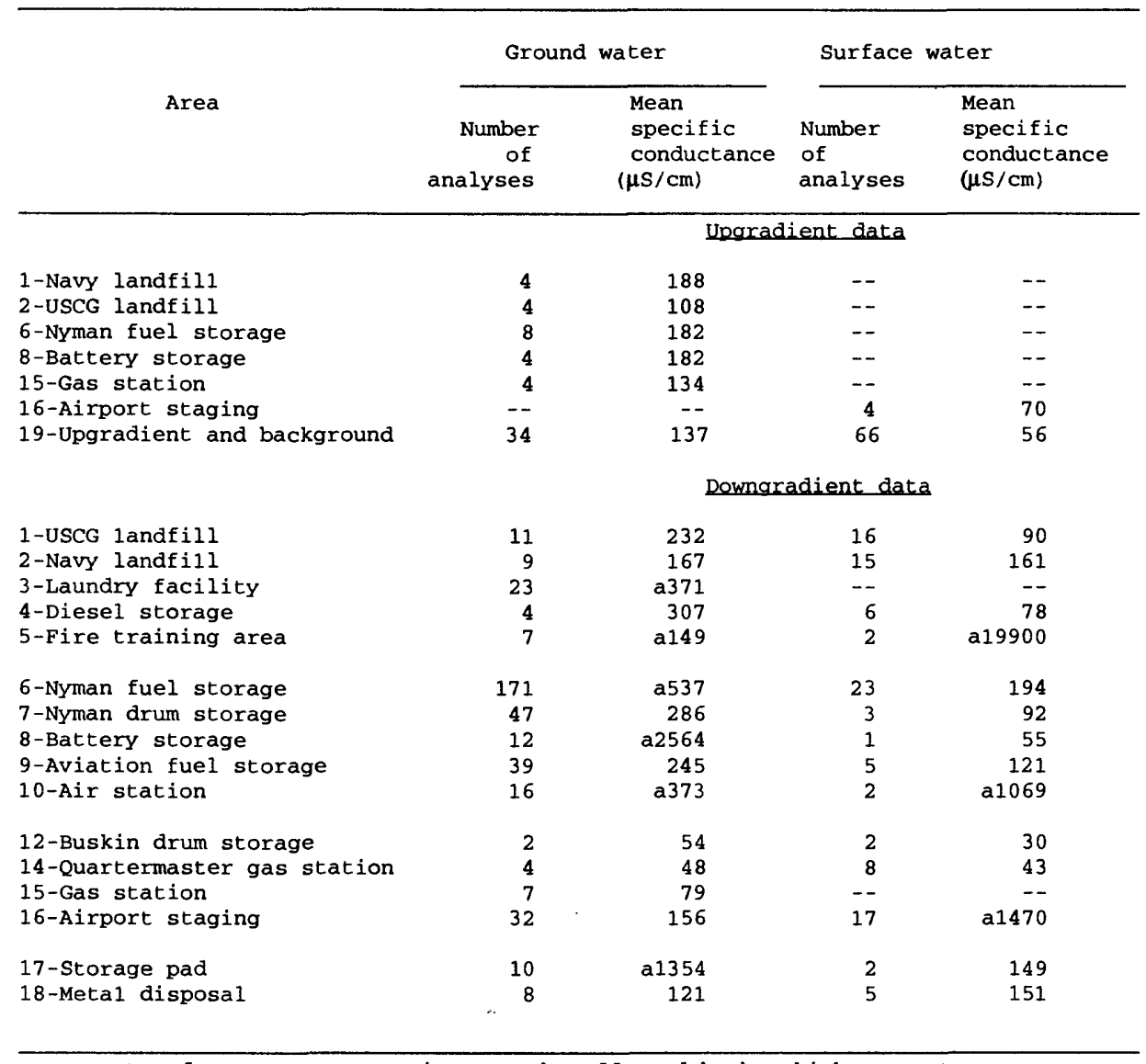

a, water from one or more sites may be affected by brackish sea water

The mean specific conductance value of ground water from background wells (Area 19) was $137 \mu \mathrm{S} / \mathrm{cm}$. The mean specific conductance values of ground water from downgradient sites in nine downgradient areas $(1,3,4,6-10,17)$ were significantly greater than the mean specific conductance value for Area 19. However, because many areas of potential contamination were near Womens Bay, the specific conductance values from many downgradient sites are affected by brackish sea water. Ground water from downgradient sites in Areas 2, 5, 15, 16, and 18 had mean specific conductance values that were not significantly different from the mean specific conductance value of the upgradient area, and in Areas 12 and 14, ground water from downgradient sites had mean specific conductance values that were significantly less than that for Area 19.

pH

The $\mathrm{pH}$ of a water is a useful index of the status of equilibrium reactions in an aqueous medium. The activity of hydrogen ions is expressed in logarithmic units and the abbreviation "pH" represents the negative base-10 log of the hydrogen ion activity in moles per liter. Ground water and surface water typically have $\mathrm{pH}$ values ranging from 6 to $8 \mathrm{pH}$ units, but lower $\mathrm{pH}$ values are commonly found in natural waters and bogs that are rich in dissolved organic matter. Values of $\mathrm{pH}$ for ground water ranged from 4.9 (A028) to 9.7 units (A030) and for surface water pH ranged from 5.8 (site 37) to 9.6 units (site 40). The median $\mathrm{pH}$ values for ground and surface waters were 6.6 and 7.2 units, respectively. The following wells yielded water having a pH value less than 6 units: 
A008, A013, A016, A017, A020A, A028, A032, A035, A041, A043, A051, A053, A059, A060, A062, A066A, A071, A075, A081, A084, B006, and B008. Surface-water sites 37 and 52 on Nyman Peninsula also had $\mathrm{pH}$ values less than 6 units. Waters having $\mathrm{pH}$ values greater than 8 units were obtained from wells A030, A033, A078, and B001 and surface-water site 40 on the Nyman Peninsula.

The mean values of $\mathrm{pH}$ (listed below) were calculated using two methods. When one is interested in proton $\left(\mathrm{H}^{+}\right)$activity and $\mathrm{pH}$ acts as an intensity factor, the mean $\mathrm{pH}$ value is calculated by the equation:

$$
\mathrm{pH}_{\text {mean }}=\frac{1}{\mathrm{n}} \sum_{i=1}^{\mathrm{n}} \mathrm{pH}_{i}
$$

where $\mathrm{pH}=-\log \left[\mathrm{H}^{+}\right]$and $\left[\mathrm{H}^{+}\right]$is the proton activity.

When one is interested in the extent to which chemicals in a system can be converted from one form to another, such as the buffering capacity of a water sample, mean $\mathrm{pH}$ is calculated by taking the $\log$ of the mean hydrogen ion activities:

$$
\mathrm{pH}_{\text {mean }}=-\log \left[\frac{1}{n} \sum_{i=1}^{n}\left[\mathrm{H}^{+}\right]_{i}\right]
$$

Water collected from upgradient sites had a $\mathrm{pH}$ similar to water sampled at downgradient sites. The mean $\mathrm{pH}$ values of upgradient and downgradient ground-water and surface-water sites are summarized below.

\begin{tabular}{lrccc}
\hline & $\begin{array}{c}\text { Number of } \\
\text { sites }\end{array}$ & $\begin{array}{c}\text { Number of } \\
\text { samples }\end{array}$ & Mean $\left(\log \left[\mathrm{H}^{+}\right]\right)$ & Log (mean $\left.\left[\mathrm{H}^{+}\right]\right)$ \\
\cline { 2 - 5 } & \multicolumn{5}{c}{ Ground water } \\
Upgradient & 10 & 34 & 6.51 & 6.39 \\
Downgradient & 91 & 304 & 6.64 & 6.28 \\
Up- and downgradient & 101 & 338 & 6.63 & 6.29 \\
& & Surface water & \\
Upgradient & 17 & 29 & 7.12 & 7.00 \\
Downgradient & 39 & 69 & 7.16 & 6.82 \\
Up- and downgradient & 56 & 98 & 7.15 & 6.85 \\
\hline
\end{tabular}

\section{Laboratory Analyses}

The results of approximately 350 ground-water samples collected from 101 wells and 110 surface-water samples collected from 59 sites on streams or lakes are shown in appendixes 3 and 4 and are summarized below. 


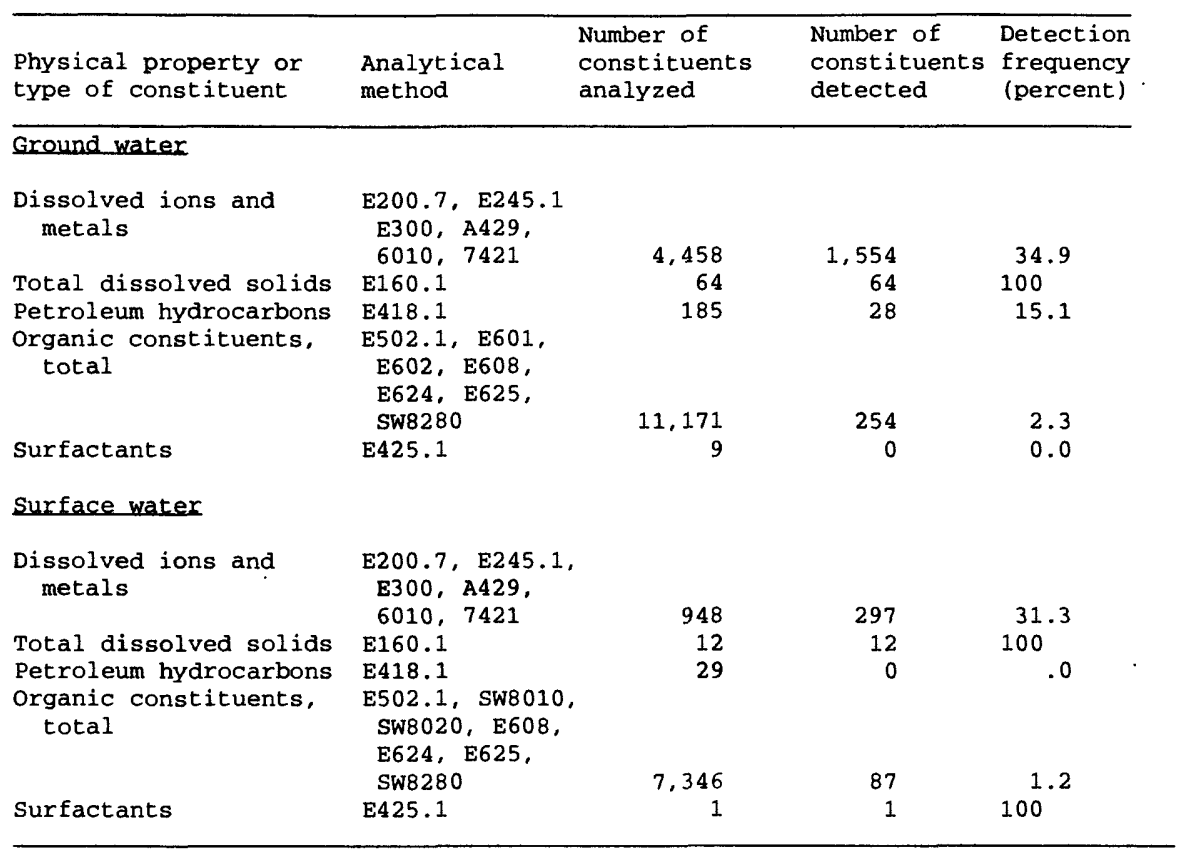

\section{Comparisons with Federal Drinking-Water Regulations}

The Maximum Contaminant Level Goals (MCLG), Maximum Contaminant Levels (MCL), and Secondary Maximum Contaminant Levels (SMCL) for drinking water contaminants referenced in this report are those established by the USEPA in compliance with the Safe Drinking Water Act Amendments of 1986. Current drinking-water regulations may be found in U.S. Environmental Protection Agency (1995) and in the Code of Federal Regulations (CFR) Volume 40, Parts 141, 142, and 143. Interim drinking-water regulations and water-quality standards are published in the Federal Register.

The MCLG is a non-enforceable concentration of a drinking-water contaminant that is protective of adverse human health effects and which allows an adequate margin of safety. The MCL is the maximum allowable level of a contaminant in drinking water which is delivered to any user of a public water system. By policy, the USEPA sets MCLG's at zero for known or probable human carcinogens and the MCL is established as close to the MCLG as feasible. The SMCL is a goal for drinking-water quality and provides a general guideline for public-water suppliers. Secondary contaminants mainly affect the aesthetic qualities of drinking water; however, at considerably higher concentrations, health problems might exist.

The chemical constituents or properties listed below are regulated and were analyzed during this study. Sites having at least one concentration of a constituent equal to or exceeding a MCLG or SMCL are noted. Sites that had a concentration greater than or equal to a MCL are listed with an asterisk. 


\begin{tabular}{|c|c|c|c|c|}
\hline Constituent & $\begin{array}{r}\text { CAS } \\
\text { number }\end{array}$ & MCLG & MCL & $\begin{array}{l}\text { Sites having at least one concentration } \\
\text { greater than or equal to the MCLG }\end{array}$ \\
\hline \multicolumn{5}{|c|}{ INORGANIC CONSTITUENTS $(\mathrm{mg} / \mathrm{L})$} \\
\hline Antimony & 7440360 & 0.006 & 0.006 & All concentrations were $<$ MCLG \\
\hline Arsenic & 7440382 & 0 & 0.05 & $\begin{array}{l}\mathrm{A} 006 \mathrm{~A}, \mathrm{~A} 007, \mathrm{~A} 010, \mathrm{~A} 018, \mathrm{~A} 021 \mathrm{~A}, \mathrm{~A} 029, \mathrm{~A} 032, \mathrm{~A} 032 \mathrm{~A}, \mathrm{~A} 033, \mathrm{~A} 034, \\
\mathrm{~A} 038, \mathrm{~A} 040, \mathrm{~A} 042, \mathrm{~A} 050, \mathrm{~A} 052, \mathrm{~A} 054, \mathrm{~A} 057, \mathrm{~A} 073, \mathrm{~A} 086, \mathrm{~B} 001, \mathrm{~B} 008, \\
\mathrm{~B} 010, \mathrm{CG} 1\end{array}$ \\
\hline Barium & 7440393 & 2. & 2 . & All concentrations were < MCLG \\
\hline Bery11ium & 7440417 & 0.004 & 0.004 & Not detected in any samples \\
\hline Cadmium & 7440439 & 0.005 & 0.005 & $\begin{array}{l}\text { A012A*, A040*, A068A*, B005*, } \\
\text { Surface-water site } 33^{*}\end{array}$ \\
\hline Chromium & 7440473 & 0.1 & 0.1 & Not detected in any samples \\
\hline Fluoride & 66300 & 4. & 4. & All concentrations < MCLG \\
\hline Mercury & 7439976 & 0.002 & 0.002 & Al1 concentrations were < MCLG \\
\hline Nickel & 7440020 & 0.1 & 0.1 & Al1 concentrations were < MCLG \\
\hline Nitrate as $\mathrm{N}$ & 25900 & 10 . & 10 & All concentrations were < MCLG \\
\hline Selenium & 7782492 & 0.05 & 0.05 & Not detected in any samples \\
\hline Sulfate & 3035 & 500 & 500 & Al1 concentrations were < MCLG \\
\hline Tha11ium & 7440280 & 0.0005 & 0.002 & Surface-water site 34 \\
\hline \multicolumn{5}{|c|}{ VOLATILE ORGANIC CARBONS $(\mu \sigma / \omega)$} \\
\hline Benzene & 71432 & 0 & 5. & $\begin{array}{l}\text { A021A*, A032, A032A*, A033, A050, A060*, A069*; } \\
\text { Surface-water sites } 24,26,39\end{array}$ \\
\hline $\begin{array}{l}\text { Carbon } \\
\text { tetra- } \\
\text { chloride } \\
\text { Chloro- }\end{array}$ & 56235 & 0 . & 5. & Not detected in any samples \\
\hline $\begin{array}{l}\text { benzene } \\
\text { 1,4-Dichloro- }\end{array}$ & 108907 & 100 & 100 & Not detected in any samples \\
\hline $\begin{array}{l}\text { benzene } \\
1,2-\text { Dichloro- } \\
\text { benzene } \\
\text { 1,2-Dichloro- }\end{array}$ & $\begin{array}{l}106467 \\
95501\end{array}$ & $\begin{array}{l}75 . \\
600\end{array}$ & $\begin{array}{l}75 . \\
600 .\end{array}$ & $\begin{array}{l}\text { Al1 concentrations were < MCLG } \\
\text { Not detected in any samples }\end{array}$ \\
\hline ethane & 107062 & 0 & 5. & 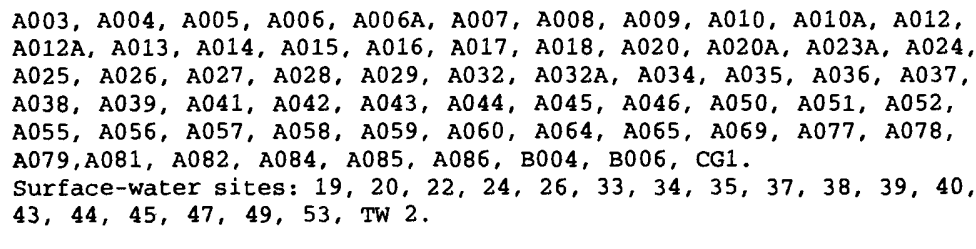 \\
\hline $\begin{array}{l}\text { 1,1-Dichloro- } \\
\text { ethene } \\
\text { trans-1,2- } \\
\text { Dichloro- }\end{array}$ & 75354 & 7 . & 7. & Al1 concentrations were $<$ MCLG \\
\hline $\begin{array}{l}\text { ethene } \\
\text { Methylene }\end{array}$ & 156605 & 100 & 100 & Al1 concentrations were < MCLG \\
\hline $\begin{array}{l}\text { chloride } \\
\text { Tetrachloro- }\end{array}$ & 75092 & 0 . & -- & A039, A085, surface-water sites 26,43 \\
\hline $\begin{array}{l}\text { ethene } \\
1,1,1 \text {-Tri- } \\
\text { chloro- }\end{array}$ & 127184 & 0 . & 5. & $\mathrm{~A} 039, \mathrm{~A} 040^{*}, \mathrm{~A} 073^{*}, \mathrm{~A} 084, \mathrm{~B} 004^{*}, \mathrm{~B} 006^{*}$ \\
\hline $\begin{array}{l}\text { ethane } \\
\text { Trichloro- }\end{array}$ & 71556 & 200 & 200 & Surface-water sites 26,43 \\
\hline $\begin{array}{l}\text { ethene } \\
1,2,4 \text {-Tri- } \\
\text { chloro- }\end{array}$ & 79016 & 0. & 5. & $\mathrm{~A} 040^{*}, \mathrm{~A} 073^{*}, \mathrm{~A} 084, \mathrm{~B} 004, \mathrm{~B} 006$ \\
\hline $\begin{array}{l}\text { benzene } \\
\text { Vinyl }\end{array}$ & 120821 & 70 . & 70 . & Not detected in any samples \\
\hline chloride & 75014 & 0 & 2. & $\begin{array}{l}\text { A006A, A007, A040*, CG 2, } \\
\text { Surface-water sites } 22,24 *, 26\end{array}$ \\
\hline
\end{tabular}




\begin{tabular}{|c|c|c|c|c|c|}
\hline Constituent & CAS number & MCLG & MCL & es having at least one concentration greater than or equal to the & MCLG \\
\hline \multicolumn{6}{|c|}{ SYNTHETIC ORGANIC CHEMICALS AND PESTICIDES $(\mu \mathrm{g} / \mathrm{L})$} \\
\hline \multicolumn{6}{|c|}{$1,1,2$-Trichloro- } \\
\hline $\begin{array}{l}\text { ethane } \\
\text { 1,2-Dichloro }\end{array}$ & 79005 & 3. & 5. & All concentrations were < MCLG & \\
\hline propane & 78875 & 0 . & 5. & Not detected in any samples & \\
\hline Benzo (a) - & & & & & \\
\hline Chlordane & 57749 & 0 . & 2 . & Not detected in any samples & \\
\hline Endrin & 72208 & 2 . & 2 . & Not detected in any samples & \\
\hline \multicolumn{6}{|c|}{ 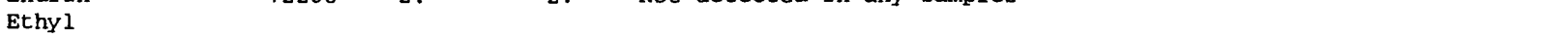 } \\
\hline benzene & 100414 & 700 . & 700. & All concentrations were < MCLG & \\
\hline \multicolumn{6}{|l|}{ Ethylene } \\
\hline dibromide & 106934 & 0. & 0.05 & Not detected in any samples & \\
\hline \multicolumn{6}{|l|}{ Heptachlor } \\
\hline epoxide & 1024573 & 0 . & 0.2 & Not detected in any samples & \\
\hline benzene & 118741 & 0 . & 1. & Not detected in any samples & \\
\hline Lindane & 58899 & 0.2 & 0.2 & Not detected in any samples & \\
\hline PCBs & 12767792 & 0 & 0.5 & Surface-water site 40 & \\
\hline \multicolumn{6}{|l|}{ Pentachloro- } \\
\hline phenol & 87865 & 0 . & 1. & Not detected in any samples. & \\
\hline styrene & 100425 & 100 & 100 & Surface-water site 40 & \\
\hline Toluene & 108883 & 1000 & 1000 & Al1 concentrations were < MCLG & \\
\hline Toxaphene & 8001352 & 0. & 5. & Not detected in any samples & \\
\hline \multicolumn{6}{|c|}{ Trihalomethanes } \\
\hline $\begin{array}{l}\text { Bromoform } \\
\text { Bromodichl }\end{array}$ & oro- & 0 & 100 . & Not detected in any samples & \\
\hline methane & 75274 & 0 . & 100. & All concentrations were $<5 \mu \mathrm{g} / \mathrm{L}$. A067, A068A, A082; TW 1, TW & 2 \\
\hline Chloroform & 67663 & 0. & 100. & $\begin{array}{l}\text { A11 concentrations were }<50 \mu \mathrm{g} / \mathrm{L} . \mathrm{A} 007, \mathrm{~A} 017, \mathrm{~A} 020, \mathrm{~A} 032 \text {, } \\
\text { A035, A04, A051, A053, A056, A064, A066A, A67, A068A, A077, } \\
\text { A082, A085, Surface-water sites 19, 37, 40, 52; TW 1, TW 2 }\end{array}$ & \\
\hline Xylenes & 1330207 & 10,000 & 10,000 & All concentrations were < MCLG & \\
\hline
\end{tabular}

SECONDARY DRINKING WATER REGULATIONS

\begin{tabular}{|c|c|c|c|}
\hline Constituent & CAS number & r SMCL & Sites having at least one concentration greater than or equal to the SMCL \\
\hline \multicolumn{4}{|c|}{ INORGANIC CONSTITUENTS $(\mathrm{mg} / \mathrm{L})$} \\
\hline Aluminum & 7429905 & 0.05 & 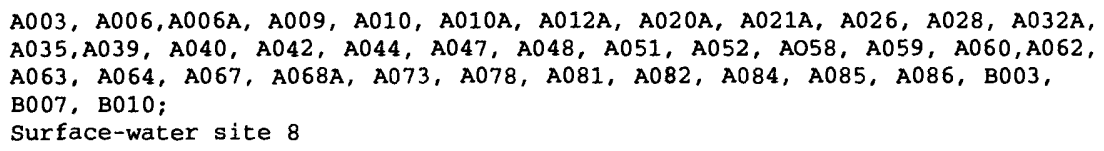 \\
\hline Chloride & 1003 & 250. & $\mathrm{~A} 044, \mathrm{~A} 050, \mathrm{~A} 086$ \\
\hline Copper & 7440508 & 1. & All concentrations were < SMCL \\
\hline Dissolved solids & 1010 & 500 . & $\begin{array}{l}\text { All concentrations were < SMCL } \\
\text { (However, specific conductance values indicate that the following sites may } \\
\text { have dissolved solids greater than } 500 \mathrm{mg} / \mathrm{L}: \mathrm{A} 018, \mathrm{~A} 037, \mathrm{A042,} A 044 \text {, } \\
\text { A050,A058, A086, B010; } \\
\text { Surface-water sites } 34,35,38 \text { ) }\end{array}$ \\
\hline Fluoride & 66300 & 2. & All concentrations were < SMCL \\
\hline Iron & 7439896 & 0.3 & $\begin{array}{l}\text { A003, A006A, A007, A009, A010, A010A, A020A, A021A, A023A, A024, A026, A027, } \\
\text { A029, A032, A032A, A033, A034, A035, A038, A039, A040, A050, A052, A054, A055, } \\
\text { A057, A060, A063, A064, A065, A067, A073, A078, A086, B008, B010, CG1 CG 2, } \\
\text { CG 3, CG 4. } \\
\text { Surface-water sites: } 20,22,24,26\end{array}$ \\
\hline Manganese & 7439965 & 0.05 & $\begin{array}{l}\mathrm{A} 001, \mathrm{~A} 001 \mathrm{~A}, \mathrm{~A} 003, \mathrm{~A} 004, \mathrm{~A} 005, \mathrm{~A} 006 \mathrm{~A}, \mathrm{~A} 007, \mathrm{~A} 008, \mathrm{~A} 009, \mathrm{~A} 010, \mathrm{~A} 010 \mathrm{~A}, \mathrm{~A} 013, \\
\mathrm{~A} 014, \mathrm{~A} 015, \mathrm{~A} 016, \mathrm{~A} 018, \mathrm{~A} 019, \mathrm{~A} 020, \mathrm{~A} 020 \mathrm{~A}, \mathrm{~A} 021 \mathrm{~A}, \mathrm{~A} 024, \mathrm{~A} 027, \mathrm{~A} 029, \mathrm{~A} 032, \\
\mathrm{~A} 032 \mathrm{~A}, \mathrm{~A} 033, \mathrm{~A} 034, \mathrm{~A} 035, \mathrm{~A} 037, \mathrm{~A} 038, \mathrm{~A} 39, \mathrm{~A} 040, \mathrm{~A} 041, \mathrm{~A} 046, \mathrm{~A} 049, \mathrm{~A} 050, \mathrm{~A} 51, \\
\mathrm{~A} 052, \mathrm{~A} 053, \mathrm{~A} 054, \mathrm{~A} 055, \mathrm{~A} 056, \mathrm{~A} 057, \mathrm{~A} 058, \mathrm{~A} 059, \mathrm{~A} 060, \mathrm{~A} 061, \mathrm{~A} 063, \mathrm{~A} 064, \mathrm{~A} 065, \\
\mathrm{~A} 069, \mathrm{~A} 070, \mathrm{~A} 071, \mathrm{~A} 073, \mathrm{~A} 075, \mathrm{~A} 079, \mathrm{~A} 081, \mathrm{~A} 082, \mathrm{~A} 084, \mathrm{~A} 085, \mathrm{~A} 086, \mathrm{~B} 001, \mathrm{~B} 002, \\
\mathrm{~B} 003, \mathrm{~B} 004, \mathrm{~B} 006, \mathrm{~B} 007, \mathrm{~B} 008, \mathrm{~B} 010, \mathrm{~B} 011, \mathrm{~B} 012, \mathrm{CG} 1, \mathrm{CG} 2, \mathrm{CG} 3, \mathrm{CG} 4 \\
\text { Surface water sites: } 19,20,22,24,26,27,57,58\end{array}$ \\
\hline Zinc & 7440660 & 5. & All concentrations were $<$ SMCL \\
\hline \multicolumn{4}{|l|}{ PROPERTY } \\
\hline $\mathrm{pH}$ & -- & $6.5-8.5$ & 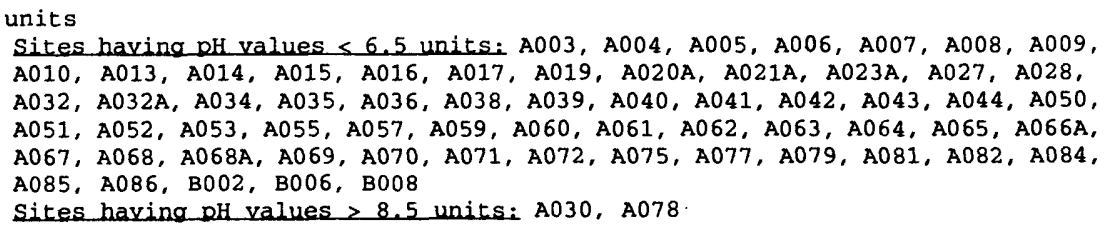 \\
\hline
\end{tabular}




\section{AREA DESCRIPTIONS}

\section{Area 19. Upgradient and Background Sites}

Sampling sites in Area 19 (fig. 3) were selected so that water properties and constituents at the sites would represent upgradient or background conditions. Wells representing upgradient or background conditions are A002A, A003, A004, A005, A009, A010, A015, A019, A020, and CG 4. One soil sample was collected for chemical analysis. At the times when water-quality samples were collected, water levels in completed wells ranged from 0.65 to $25.47 \mathrm{ft}$ below land surface. Surface-water sites include 2, Buskin Lake Tributary (Northwest); 3, Buskin Lake Tributary (West); 4, Buskin Lake (Station 1); 5, Bear Creek at mouth; 6, Buskin Lake (Station 2); 7, Buskin River below lake; 11, Alder Creek at BB Road; 14, Buskin River 0.9 mi below Buskin Lake; 15, Alder Creek at G Road; 16, Unnamed Tributary 1 to Buskin River; 18, Magazine Creek at $0.9 \mathrm{mi}$ Anton Larsen Bay Road; 27, Lake Louise Outlet; 28, Unnamed Tributary 2 to Buskin River; 32, Devils Creek above runway below highway; 55, Unnamed Creek north of Buskin Lake; 57, Catherine (Margaret) Lake; 58, Genivieve Lake; and 61, Devils Creek.

Only one soil sample from background sites was chemically analyzed, from A002A-05 near Buskin Lake. Constituents analyzed were lead, 34 organic chemicals, and TPH. Lead was detected at a concentration of $2 \mathrm{mg} / \mathrm{kg}$. No organic chemicals were present at concentrations higher than reporting levels and the concentration of TPH was less than the $50 \mathrm{mg} / \mathrm{kg}$ reporting level.

Thirty-six ground-water samples were collected from 10 wells for measurements of temperature, specific conductance, $\mathrm{pH}$, and analyses for selected chemical constituents. The constituents that were analyzed from each sample varied. Some samples were analyzed only for lead and chloride concentrations, whereas other samples were analyzed for various organic and inorganic constituents because of nearby potential sources of contamination.

Surface-water samples were collected at 18 sites. Thirty-one sets of measurements for temperature, specific conductance, and $\mathrm{pH}$ were made; some sets include numerous measurements of field properties across the width or depth of a stream or lake. As with ground water, the constituents that were analyzed varied among the sites.

The following is a list of selected constituents detected in water samples from upgradient and background sites. Sites having a water sample that had one or more concentrations greater than or equal to the MCL for drinking water are marked with an asterisk. 


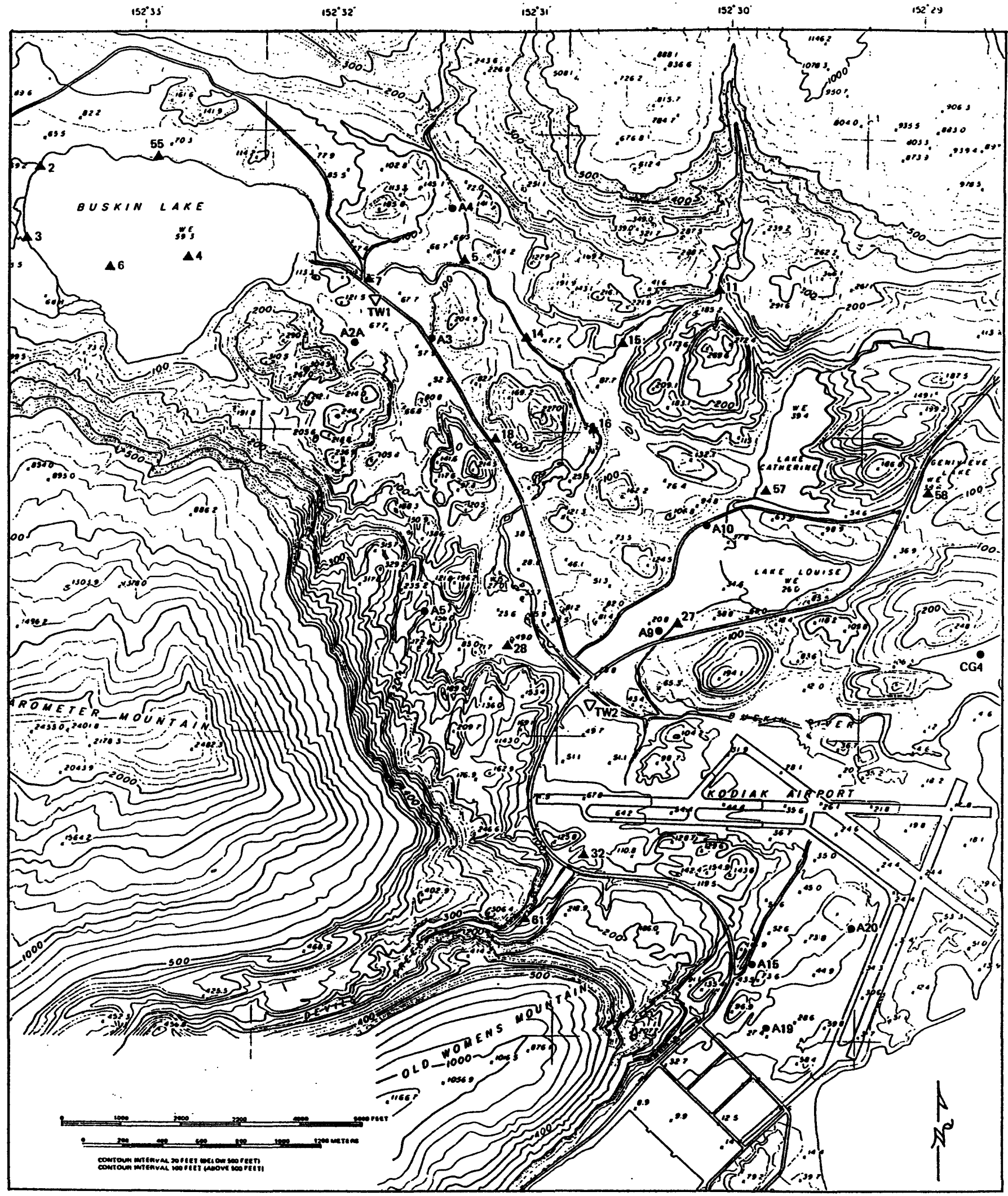

$\nabla$ TW1 Treated-water sampling site and number

16 Surface-water sampling site and number

A5 Well or borehole sampling site and number

Figure 3. Area 19, Upgradient and background sites. 


\begin{tabular}{|c|c|c|c|}
\hline Constituent & $\begin{array}{l}\text { CAS } \\
\text { number }\end{array}$ & MCLG & $\begin{array}{l}\text { Sites having at least one concentration } \\
\text { greater than or equal to the MCLG }\end{array}$ \\
\hline \multicolumn{4}{|c|}{ INORGANIC CONSTITUENTS (mg/L) } \\
\hline $\begin{array}{l}\text { Arsenic } \\
\text { Lead }\end{array}$ & $\begin{array}{l}7440382 \\
7439921\end{array}$ & $\begin{array}{ll}0 . & 0.05 \\
0 . & 0.005\end{array}$ & $\begin{array}{l}\text { A010 } \\
\text { Surface-water site } 7 \text { * }\end{array}$ \\
\hline \multicolumn{4}{|c|}{ ORGANIC CONSTITUENTS $(\mu \mathrm{g} / \mathrm{L})$} \\
\hline $\begin{array}{l}\text { 1.2-Dichlor } \\
\text { ethane } \\
\text { Chloroform }\end{array}$ & $\begin{array}{r}107062 \\
67663\end{array}$ & $\begin{array}{lr}0 . & 5 \\
0 . & 100\end{array}$ & $\begin{array}{l}\mathrm{A} 003, \mathrm{~A} 004, \mathrm{~A} 005, \mathrm{~A} 009, \mathrm{~A} 010, \mathrm{~A} 015, \mathrm{~A} 020 \\
\mathrm{~A} 020\end{array}$ \\
\hline Constituent & $\begin{array}{l}\text { CAS } \\
\text { number }\end{array}$ & $\begin{array}{l}\text { SMCL } \\
(\mathrm{mg} / \mathrm{L})\end{array}$ & $\begin{array}{l}\text { Sites having at least one concentration } \\
\text { greater than or equal to the SMCL }\end{array}$ \\
\hline $\begin{array}{l}\text { Aluminum } \\
\text { Iron } \\
\text { Manganese }\end{array}$ & $\begin{array}{l}7429905 \\
7439896 \\
7439965\end{array}$ & $\begin{array}{l}0.05 \\
0.3 \\
0.05\end{array}$ & $\begin{array}{l}\text { A003, A009, A010 } \\
\text { A003, A010, CG } 4 \\
\text { A003, A004, A005, A009, A010, A015, A019, A020, CG } 4 \\
\text { Surface-water sites 27, } 57,58\end{array}$ \\
\hline
\end{tabular}

The following selected constituents do not have MCLG's or SMCL's but were detected in water samples:

\begin{tabular}{lrl}
\hline Constituent & CAS number & Sites having constituent detected at least once \\
\hline $\begin{array}{l}\text { bis (2-ethylhexyl)phthalate } \\
\text { Total Petroleum Hydrocarbons }\end{array}$ & $\begin{array}{l}117817 \\
\text { S }\end{array}$ & $\begin{array}{l}\text { Surface-water sites } 7,15 \text { and } 32 \\
\text { A004, A020 }\end{array}$ \\
\hline
\end{tabular}

Concentrations of arsenic from well A010 ranged from 0.006 to $0.16 \mathrm{mg} / \mathrm{L}$. In a sample taken by the USGS on May 1969 from Buskin River below Buskin Lake (site 7), lead had a concentration of $0.02 \mathrm{mg} / \mathrm{L}$. 1,2-dichloroethane was detected in water from numerous background wells in concentrations as great as $1 \mu \mathrm{g} / \mathrm{L}$, however, this constituent was also detected in numerous quality-control samples at concentrations as great as $2.6 \mu \mathrm{g} / \mathrm{L}$ and may be a laboratory contaminant or a contaminant in the organic-free distilled water that was used to rinse sampling equipment. Chloroform is a suspected human carcinogen that is widely distributed in the environment and is found in minute quantities in many municipal drinking supplies (Lucius and others, 1989, p. 205). It was detected in the chlorinated treated-water samples collected from a water-treatment plant (site TW 1, 6.2 $\mu \mathrm{g} / \mathrm{L}$ ) and a hotel (site TW 2, 2.6 and $5.4 \mu \mathrm{g} / \mathrm{L}$ ). Chlorination of water containing organic carbon (such as plant and animal debris and humic substances) can lead to formation of trihalomethane compounds such as chloroform. Buskin River (site 7) had concentrations of bis(2ethylhexyl)phthalate of $7,<20$, and $270 \mu \mathrm{g} / \mathrm{L}$. Phthalates are commonly associated with plastics. Among the background wells, A003 yielded water having the highest aluminum concentration, which ranged from 0.07 to $0.52 \mathrm{mg} / \mathrm{L}$. All samples from background streams had aluminum concentrations lower than $0.05 \mathrm{mg} / \mathrm{L}$. Well A010 yielded water having iron concentrations ranging from 6 to $11 \mathrm{mg} / \mathrm{L}$. Concentrations of iron were lower than $0.05 \mathrm{mg} / \mathrm{L}$ in all samples from background streams. Dissolved manganese in water from well A020 ranged from 1.0 to $3.3 \mathrm{mg} / \mathrm{L}$, whereas water in Genivieve Lake (site 58) had $0.41 \mathrm{mg} / \mathrm{L}$ dissolved manganese. TPH concentrations in waters from well $\mathrm{A} 004$ and $\mathrm{A} 020$ ranged from $<0.5$ to 1.0 and $<0.5$ to $0.5 \mathrm{mg} / \mathrm{L}$. However, naturally occurring organic carbons can make up part or all of the hydrocarbons in the TPH analyses. 


\section{Area 1. Former U.S. Coast Guard Landfill}

Area 1 (fig. 4) is a landfill in a small elevated glacial valley east of the Buskin River that was used by the USCG from the early 1970's until 1987. Domestic refuse is the predominant component of the landfill's contents; however, several thousand gallons of paint may have been discarded into the landfill and fuel-contaminated soils reportedly were used as cover material. Upon landfill closure the USCG installed three monitoring wells (CG 1, CG 2 and CG 3) at the site. Closure procedures were approved by the Alaska Department of Environmental Conservation. Because of surface-water staining, however, there is concern that contaminants may be seeping into the Buskin River or Lake Louise.

No upgradient wells were drilled and no upgradient samples were collected. A total of 13 downgradient water-quality samples were collected from three USCG monitoring wells and from two wells drilled by the USGS (A007 and A010A). A soil sample from A010A was also chemically analyzed. A total of 13 water samples were also collected from three drains near the landfill that have orange-colored stained channels (surface-water sites 19, 20, and 22) and from two sites on the Buskin River (sites 17 and 21). Streamflows measured in the three drains were less than $0.01 \mathrm{ft}^{3} / \mathrm{s}$. Water levels in wells A007 and A010A ranged from 8.00 to 10.70 and 0.22 to $2.11 \mathrm{ft}$ below land surface. Measurements of water levels in wells CG 1, CG 2 and CG 3 on May 24, 1989 were 10.35, 5.35 and $3.94 \mathrm{ft}$, respectively, below land surface.

Lead was detected in the soil sample from A010A at $10 \mathrm{mg} / \mathrm{kg}$. All organic chemical constituents in the soil sample were less than analytical reporting levels.

The following is a list of selected constituents detected in water samples in or downgradient from the USCG landfill. Only sites having a water sample that had one or more concentrations that were greater than or equal to a MCLG or a SMCL are listed. Concentrations of all constituents were lower than the MCL's for drinking water.

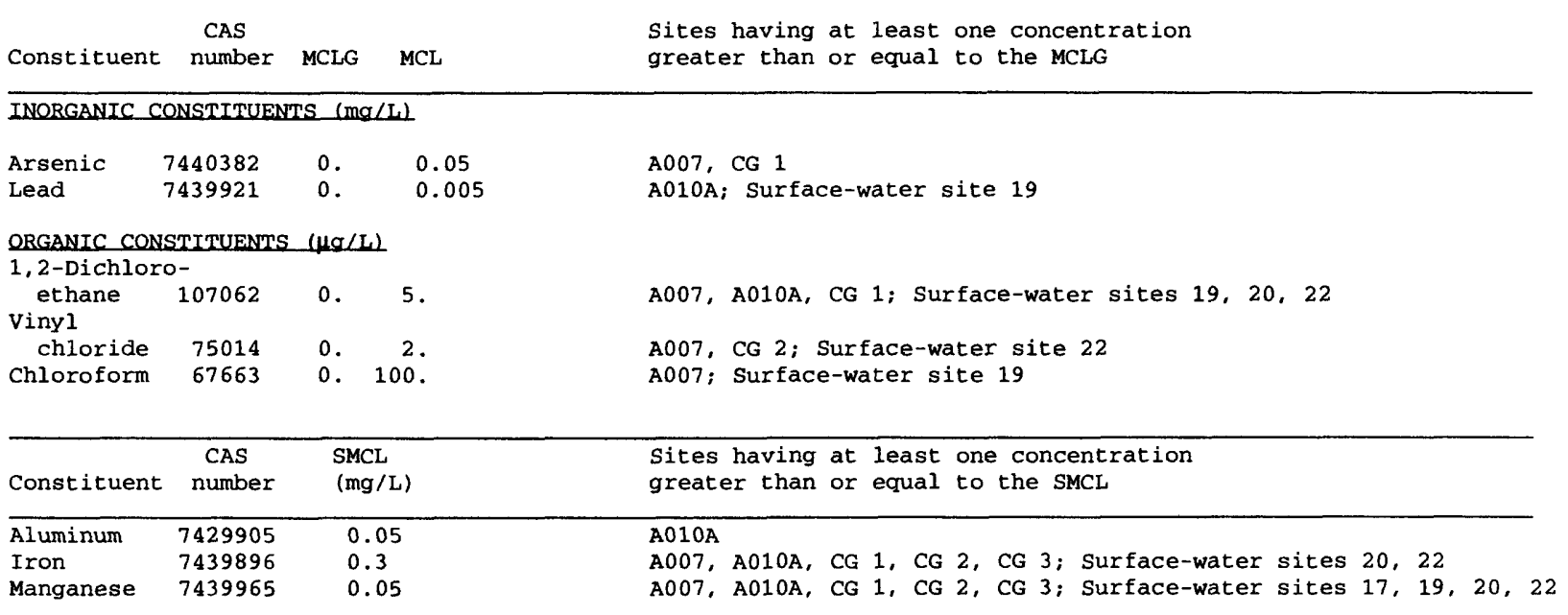




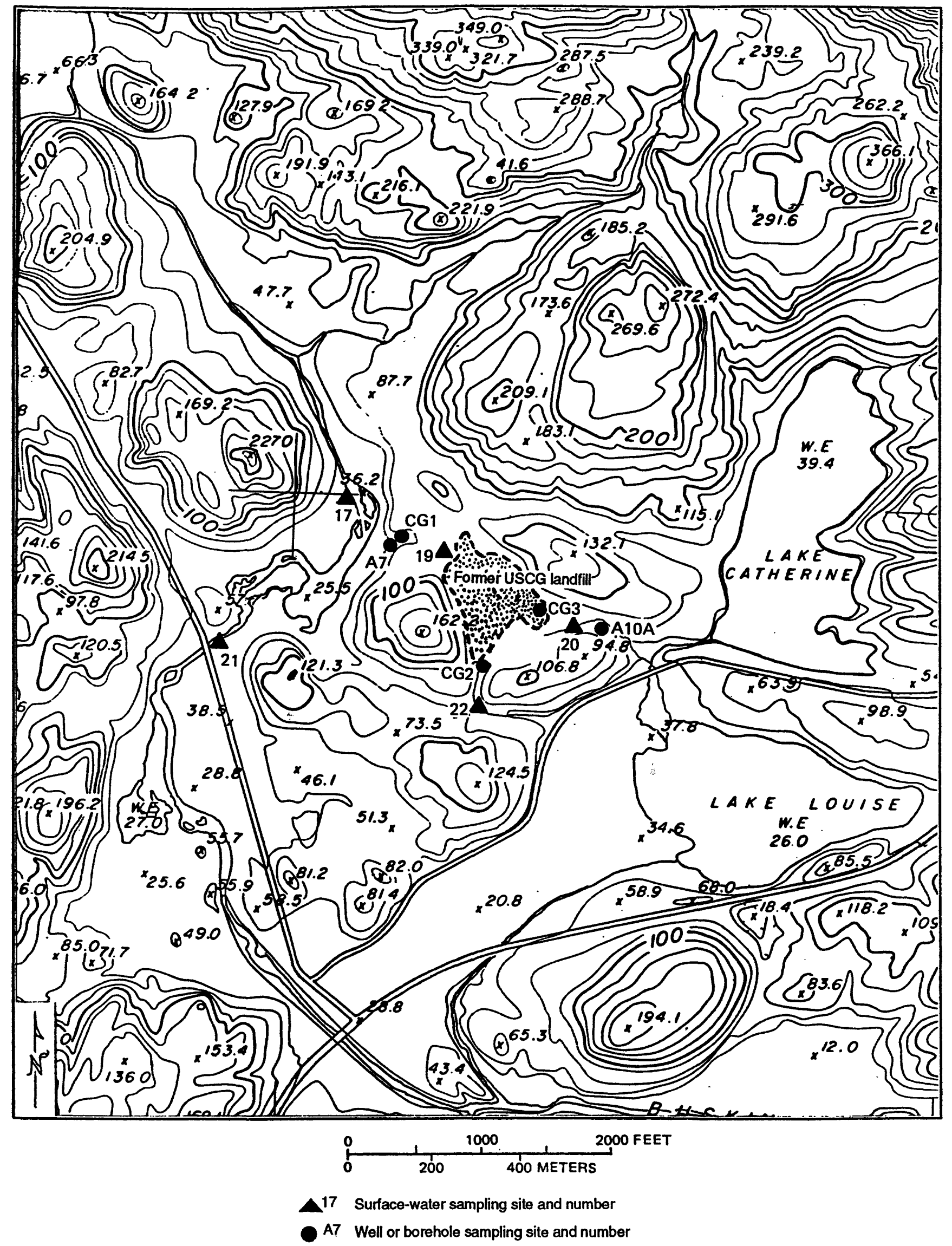

Figure 4. Area 1, the former U.S. Coast Guard landfill. 
The following selected constituents do not have MCLG's or SMCL's but were detected in water samples downgradient from the former USCG landfill:

\begin{tabular}{|c|c|c|}
\hline Constituent & $\begin{array}{c}\text { CAS } \\
\text { number }\end{array}$ & $\begin{array}{l}\text { Sites having constituent detected } \\
\text { at least once }\end{array}$ \\
\hline $\begin{array}{l}\text { Dichlorodifluoromethane } \\
\text { bis ( } 2 \text {-Ethylhexy } 1) \text { phthalate } \\
\text { Total petroleum hydrocarbons }\end{array}$ & $\begin{array}{r}75718 \\
117817 \\
5289290400\end{array}$ & $\begin{array}{l}\text { Surface-water site } 19 \\
\text { Surface-water site } 22 \\
\text { CG 1, CG 2, CG } 3\end{array}$ \\
\hline
\end{tabular}

Concentrations of dissolved arsenic were as great as $0.011 \mathrm{mg} / \mathrm{L}$ in waters from well A007 and CG 1. Lead concentrations ranged from $<0.002$ to $0.003 \mathrm{mg} / \mathrm{L}$ in water from $\mathrm{A} 010 \mathrm{~A}$ and was $0.003 \mathrm{mg} / \mathrm{L}$ in a sample from the Coast Guard Landfill Drain North at site 19. Bis(2-ethylhexyl)phthalate was present at $460 \mu \mathrm{g} / \mathrm{L}$ in a water sample recovered from a drain at the landfill (site 22) on May 11,1988 , but was not detected at a $10 \mu \mathrm{g} / \mathrm{L}$ reporting level in a subsequent sample. 


\section{Area 2. Former U.S. Navy Landfill}

Area 2 (fig. 5) is an abandoned U.S. Navy landfill in a valley east of the Buskin River. Possibly opened in the 1940's, the landfill was closed before 1972. The type of refuse in the landfill is not known, but the landfill may contain domestic refuse as well as petroleum-based products such as solvents, degreasers, and paints. A thin layer of glacial till overlies bedrock throughout most of the area near the landfill. Water in two ponds west and south of the landfill (surface-water sites 23 and 25) is red and a small lake between the landfill and Anton Larsen Bay Road is called Red Lake. The ponds overflow periodically onto equipment-storage pads near Anton Larsen Bay Road and the overflow commonly reaches the Buskin River.

One upgradient soil and four water-quality samples were collected at well A078. A soil sample from A006A and a lake-bed material sample from the center of Red Lake were also chemically analyzed. Downgradient water-quality samples were collected from wells A006 and A006A, a pond (site 23), Red Lake (site 25), an inlet to and an outlet from Red Lake (sites 24 and 26), and two sites on the Buskin River (sites 29 and 30). Water levels in well A006A near the landfill ranged from 0.72 to $3.03 \mathrm{ft}$ below land surface. Measured flows into and out of Red Lake were $0.05 \mathrm{ft}^{3} / \mathrm{s}$ or less.

Lead was detected in soil samples from A006A-05 $(15 \mathrm{mg} / \mathrm{kg})$ and A078-05 $(13 \mathrm{mg} / \mathrm{kg})$ and from Red Lake bed material ( $24 \mathrm{mg} / \mathrm{kg}$ ). All organic constituents from soil and lake-bed material samples were less than reporting levels.

The following is a list of selected constituents detected in ground water and surface water near the former Navy landfill. Sites having a water sample with a concentration higher than the MCL for drinking water are listed with an asterisk.

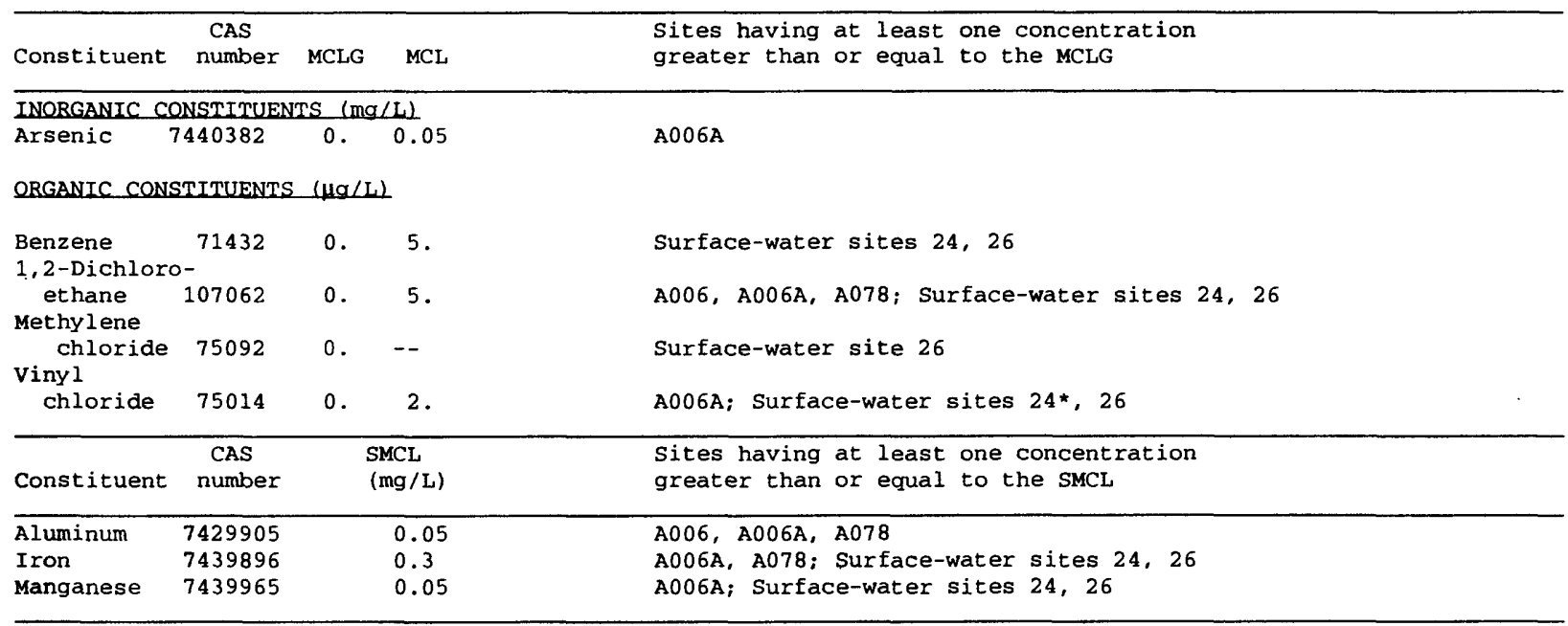

The following selected constituents do not have MCLG's or SMCL's, but were detected in water samples: 


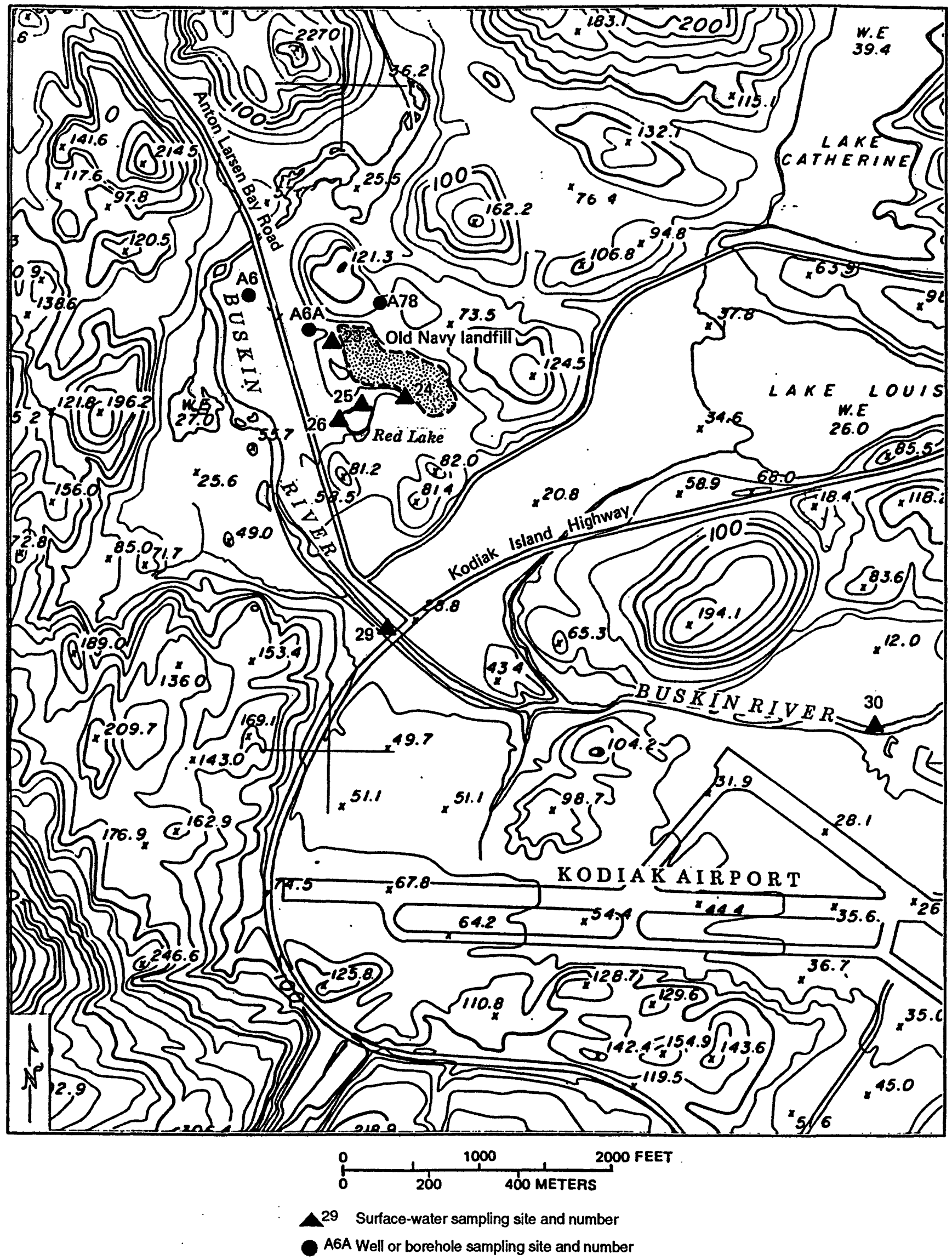

Figure 5. Area 2, the former U.S. Navy landfill. 


\begin{tabular}{lcl}
\hline Constituent & $\begin{array}{c}\text { CAS } \\
\text { number }\end{array}$ & $\begin{array}{l}\text { Sites having constituent detected } \\
\text { at least once }\end{array}$ \\
\hline $\begin{array}{l}\text { Dichlorodifluoromethane } \\
\text { Diethyl phthalate }\end{array}$ & $\begin{aligned} 75718 \\
844622\end{aligned}$ & $\begin{array}{l}\text { Surface-water sites 23, 24 } \\
\text { Surface-water site 26 }\end{array}$ \\
\hline
\end{tabular}

Ground water from well A006A had arsenic concentrations as great as $0.006 \mathrm{mg} / \mathrm{L}$. Water in an inlet ditch to Red Lake (site 24) had benzene concentrations of $<0.7$ and $0.6 \mu \mathrm{g} / \mathrm{L}$, while water in the outlet ditch (site 26) had benzene concentrations of $<0.7$ and $0.2 \mu \mathrm{g} / \mathrm{L}$. Concentrations of vinyl chloride ranged from 5.4 to $15 \mu \mathrm{g} / \mathrm{L}$ in water from the inlet to Red Lake. Diethyl phthalate was present at $22 \mu \mathrm{g} / \mathrm{L}$ in water flowing out of the lake, but was not detected in a water sample from the inlet. 


\section{Area 3. U.S. Coast Guard Laundry}

The USCG laundry facility is on the northeastern Nyman Peninsula (fig. 6). The facility has been in operation since about 1940 . Before 1987, laundry personnel periodically disposed of drycleaning wastes (possibly as much as 5 gal per week) onto the ground near the south exit of the building. The laundry is on compacted fill that consists mostly of sand and pebble-cobble gravel with lenses of volcanic ash, silt, and peat. Depth to bedrock varies widely. Bedrock is exposed southwest of the laundry building and is more than $25 \mathrm{ft}$ below land surface at well A037.

Wells A035, A036, A037, A039, A040 and A041 were drilled by the USGS in 1988 and B004, B005 and B006 were drilled in 1989. Well A041 is upgradient from the laundry facility, whereas the others are downgradient. However, well A041 is downgradient from a fuel storage area (Area 6) and a former aviation gasoline storage area (Area 9). Ten soil samples were analyzed, at least one soil sample from each well drilled. No surface-water sites near the laundry were sampled. Water levels in downgradient wells ranged from $1.11 \mathrm{ft}$ below land surface in well A040 to $16.09 \mathrm{ft}$ below land surface in A037. Water levels in A041, the upgradient well, ranged from 1.25 to $4.60 \mathrm{ft}$ below land surface.

Lead was detected in all soil samples and ranged from $1.2 \mathrm{mg} / \mathrm{kg}$ (A040-05) to $17 \mathrm{mg} / \mathrm{kg}$ (A039-04). Vinyl chloride was detected in soil from well A040-05 at $0.22 \mathrm{mg} / \mathrm{kg}$. Tetrachloroethene was detected in soil samples from B005-03.5 $(1.1 \mathrm{mg} / \mathrm{kg})$, B006-06 $(1.0 \mathrm{mg} / \mathrm{kg})$, and B006$22(0.48 \mathrm{mg} / \mathrm{kg})$. TPH in soils from A040-05 $(260 \mathrm{mg} / \mathrm{kg})$ and B006-06 $(60 \mathrm{mg} / \mathrm{kg})$ were at concentrations greater than the proposed state cleanup target levels for a gasoline release (ADEC, 1990).

The following is a list of selected constituents detected in 29 water samples from 9 wells near the laundry. Sites listed with an asterisk indicate that a concentration was detected that exceeded the MCL for drinking water.

\begin{tabular}{|c|c|c|c|}
\hline Constituent & $\begin{array}{l}\text { CAS } \\
\text { number }\end{array}$ & MCLG & $\begin{array}{l}\text { Sites having at least one concentration } \\
\text { greater than or equal to the MCLG }\end{array}$ \\
\hline \multicolumn{4}{|c|}{ INORGANIC CONSTITUENTS $(\mathrm{mg} / \mathrm{L}$ ) } \\
\hline $\begin{array}{l}\text { Arsenic } \\
\text { Cadmium } \\
\text { Lead }\end{array}$ & $\begin{array}{l}7440382 \\
7440439 \\
7439921\end{array}$ & $\begin{array}{l}0 . \\
0.005 \\
0 .\end{array}$ & $\begin{array}{l}\mathrm{A} 040 \\
\mathrm{A040*}, \mathrm{B} 005^{*} \\
\mathrm{~A} 035, \mathrm{~A} 037, \mathrm{~A} 039\end{array}$ \\
\hline \multicolumn{4}{|c|}{$\frac{\text { ORGANIC CONSTITUENTS }(\mu \mathrm{g} / \mathrm{L})}{1,2-\mathrm{Dich} 1 \text { oro- }}$} \\
\hline $\begin{array}{l}\text { ethane } \\
\text { Methylene }\end{array}$ & 107062 & 0 & $\mathrm{~A} 035, \mathrm{~A} 036, \mathrm{~A} 037, \mathrm{~A} 039, \mathrm{~A} 041, \mathrm{~B} 004, \mathrm{~B} 006$ \\
\hline $\begin{array}{r}\text { chloride } \\
\text { Tetrachloro }\end{array}$ & 75092 & 0. & A039 \\
\hline $\begin{array}{l}\text { ethene } \\
\text { Trichloro- }\end{array}$ & 127184 & 0. & $\mathrm{~A} 039, \mathrm{~A} 040^{\star}, \mathrm{B} 004^{\star}, \mathrm{B} 005^{\star}, \mathrm{B} 006^{\star}$ \\
\hline $\begin{array}{l}\text { ethene } \\
\text { Vinyl }\end{array}$ & 79016 & 0 . & 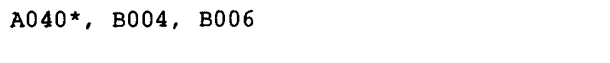 \\
\hline Constituent & $\begin{array}{l}\text { CAS } \\
\text { number }\end{array}$ & $\begin{array}{l}\text { SMCL } \\
(\mathrm{mg} / \mathrm{L})\end{array}$ & $\begin{array}{l}\text { Sites having at least one concentration } \\
\text { greater than or equal to the SMCL }\end{array}$ \\
\hline Aluminum & 7429905 & 0.05 & $\mathrm{~A} 035, \mathrm{~A} 039, \mathrm{~A} 040$ \\
\hline Iron & 7439896 & 0.3 & $\mathrm{~A} 035, \mathrm{~A} 039, \mathrm{~A} 040$ \\
\hline Manganese & 7439965 & 0.05 & $\mathrm{~A} 035, \mathrm{~A} 036, \mathrm{~A} 037, \mathrm{~A} 039, \mathrm{~A} 040, \mathrm{~B} 004, \mathrm{~B} 006$ \\
\hline
\end{tabular}




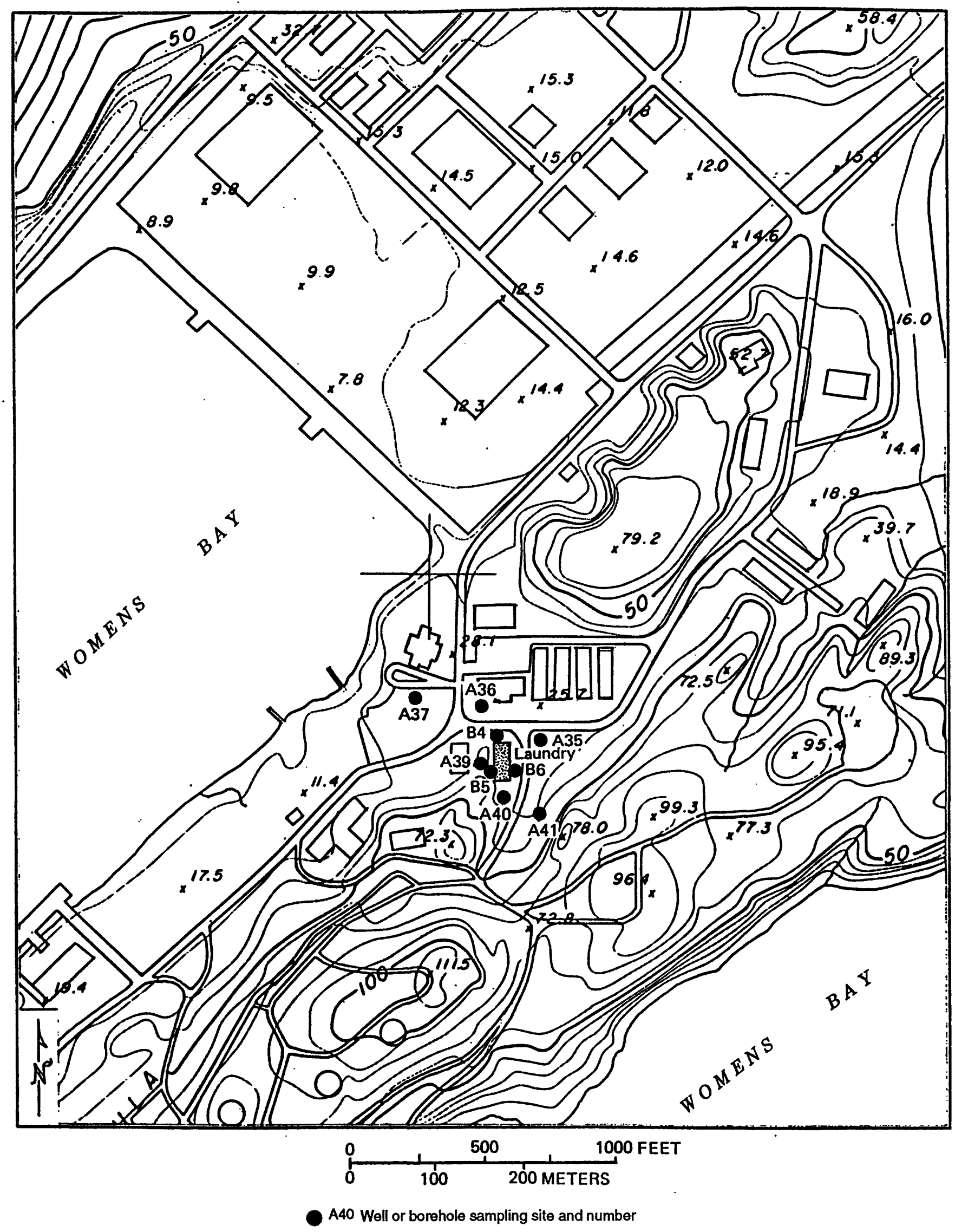

Figure 6. Area 3, the U.S. Coast Guard laundry. 
The following selected constituents do not have MCLG's or SMCL's but were detected in water samples:

The only organic constituent detected in water from the upgradient well (A041) was 1,2dichloroethane, a compound that is commonly a sampling or laboratory contaminant. Methylene chloride was present at $180 \mu \mathrm{g} / \mathrm{L}$ in a water sample collected from well A039 on March 8, 1989, but was not detected at the $2 \mu \mathrm{g} / \mathrm{L}$ level in three other samples collected from the well on other dates. Well B005 on the west side of the laundry building yielded water with a tetrachloroethene concentration of 3,000 $\mu \mathrm{g} / \mathrm{L}$. Wells north (B004), east (B006) and south (A040) of the laundry had tetrachloroethene concentrations as great as 12,19 , and $21 \mu \mathrm{g} / \mathrm{L}$, respectively. A040, B004 and B006 also yielded waters having high trichloroethene concentrations, as great as $49,0.74$, and $3.9 \mu \mathrm{g} / \mathrm{L}$. Concentrations of vinyl chloride in water from A040 ranged from 230 to $440 \mu \mathrm{g} / \mathrm{L}$. 


\section{Area 4. Former Diesel Storage Area}

Area 4 is in a small valley about $2 \mathrm{mi}$ north of the airport (fig. 7). Used as a diesel fuel storage area since the 1940's by the U.S. Army and the USCG, the site is now the location of an electric substation belonging to the Kodiak Electric Association. Diesel storage tanks were adjacent to Building 477 and others were located about $270 \mathrm{ft}$ southeast of the building. Numerous small leaks occurred in the tanks and the distribution lines, and the odor of diesel fuel is present at the site. Surficial sediments in the area consist of compacted sand and gravel fill above layers of ash, peat, and till.

No upgradient wells were drilled and no upgradient samples were collected. A soil sample and four water samples from well A024 were chemically analyzed. Downgradient water-quality samples were also collected from three unnamed streams, twice from site 8 and once from sites 9 and 10 . Streamflows at sites 8,9 , and 10 during late July 1987 were estimated to be $<0.01,0.2$, and $0.4 \mathrm{ft}^{3} / \mathrm{s}$, respectively. Water levels in well A024 ranged from 3.77 to $6.39 \mathrm{ft}$ below land surface.

The following is a list of selected constituents detected in water samples downgradient from the former diesel storage site. No concentrations exceeded MCL's for drinking water.

\begin{tabular}{|c|c|c|}
\hline $\begin{array}{c}\text { CAS } \\
\text { Constituent number }\end{array}$ & MCLG & $\begin{array}{l}\text { Sites having at least one concentration } \\
\text { greater than or equal to the MCLG }\end{array}$ \\
\hline \multicolumn{3}{|c|}{ INORGANIC CONSTITUENTS $(\mathrm{mg} / \mathrm{L})$} \\
\hline 7439921 & .005 & $\mathrm{~A} 024$ \\
\hline \multicolumn{3}{|c|}{$\frac{\text { ORGANIC CONSTITUENTS }(\mu \sigma / L)}{1,2 \text {-Dichloro- }}$} \\
\hline $\begin{array}{c}\text { CAS } \\
\text { Constituent number }\end{array}$ & $\begin{array}{l}\text { SMCL } \\
(\mathrm{mg} / \mathrm{L})\end{array}$ & $\begin{array}{l}\text { Sites having at least one concentration } \\
\text { greater than or equal to the SMCL }\end{array}$ \\
\hline $\begin{array}{ll}\text { Aluminum } & 7429905 \\
\text { Iron } & 7439896 \\
\text { Manganese } & 7439965\end{array}$ & $\begin{array}{l}0.05 \\
0.3 \\
0.05\end{array}$ & $\begin{array}{l}\text { Surface-water site } 8 \\
\text { A024 } \\
\text { A024 }\end{array}$ \\
\hline
\end{tabular}

The following selected constituents do not have MCLG's or SMCL's but were detected in water samples:

\begin{tabular}{lcl}
\hline Constituent & CAS number & Sites having constituent detected at least once \\
\hline bis (2-Ethylhexyl)phthalate & 117817 & Surface-water site 8 \\
Di-n-octyl phthalate & 117840 & Surface-water site 8 \\
Diethyl phthalate & 844622 & Surface-water site 9 \\
\hline
\end{tabular}

Lead was detected in the soil samples from A024-03 at $0.6 \mathrm{mg} / \mathrm{kg}$. Lead concentrations in water from A024 was $0.007 \mathrm{mg} / \mathrm{L}$ in one sample, but lead was not detected in three other water samples from A024 at the $0.002 \mathrm{mg} / \mathrm{L}$ detection level. Toluene and 1,2-dichloroethane were each detected once at low concentrations $(<3 \mu \mathrm{g} / \mathrm{L})$ at well $\mathrm{A} 024$, but were not detected during the analyses of three other samples taken from the well on other dates. 


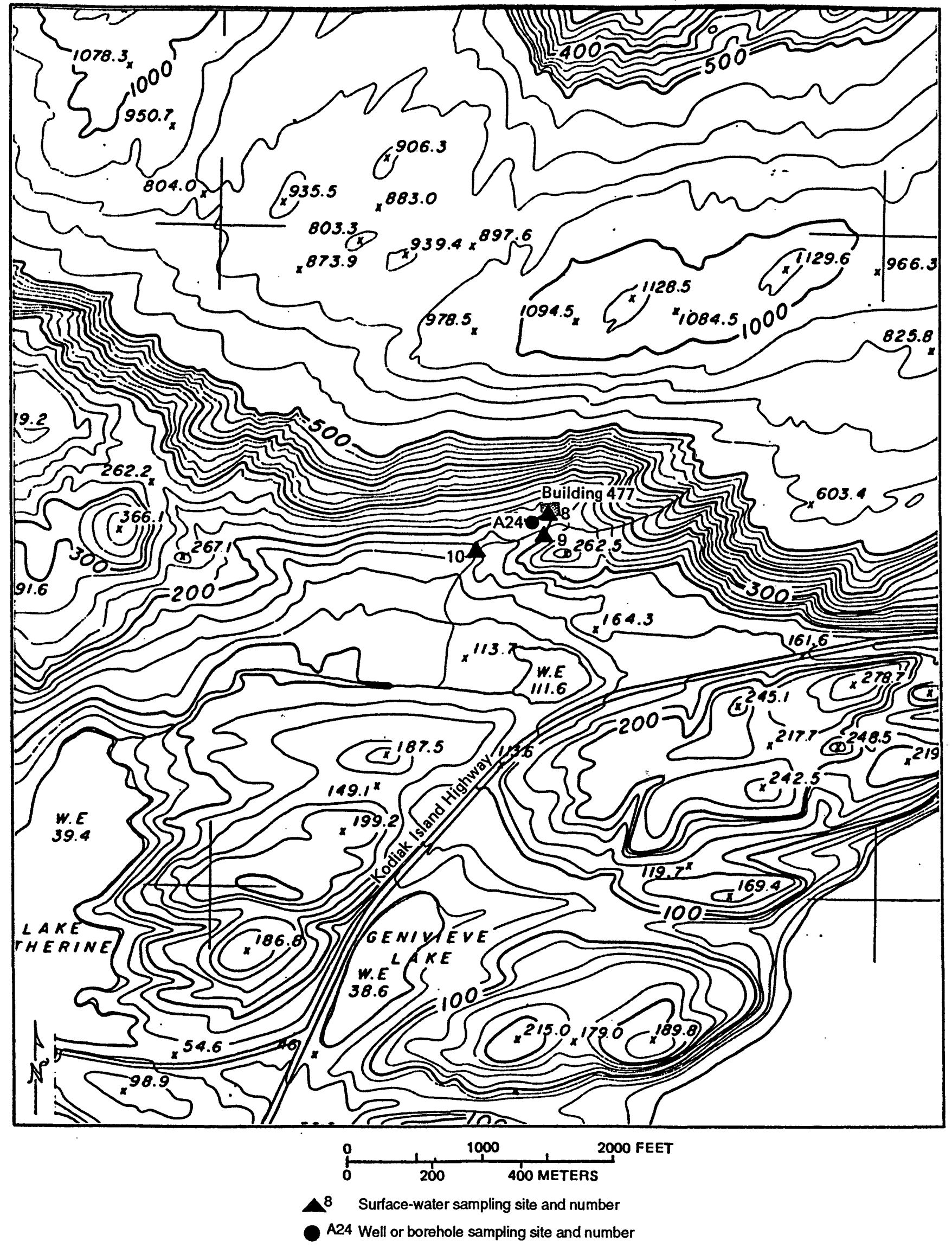

Figure 7. Area 4, a former U.S. Army diesel storage area. 


\section{Area 5. Former Fire-Fighting Training Area}

A former fire-fighting training area (Area 5) is between the airport's north-south runway and Womens Bay (fig. 8). In this area, fuels and other flammable liquids were burned intermittently in an unlined pit from about 1979 through 1987. Most of the training area is on compacted fill that consists of silt, sand, and gravel. Bedrock with near-vertical bedding is exposed northwest of the abandoned training pit. Bedrock is present $2 \mathrm{ft}$ below land surface in wells A023 and B001, but was not penetrated during the drilling of wells A023A, B002, or B003 (24 to $45 \mathrm{ft}$ deep). Drilling at site A023 was terminated at the bedrock surface ( $2 \mathrm{ft}$ below land surface) and casing was not installed in the borehole. Drilling at site B001 continued through bedrock to a depth of $71 \mathrm{ft}$ below land surface but the borehole was backfilled to $40 \mathrm{ft}$ with drill cuttings. No upgradient wells were drilled. Soil samples were collected during the drilling of wells A023A, B001, B002, and B003. Near-surface soil samples were also collected in the burn pit (B013) and about $20 \mathrm{ft}$ from the pit (B014). A total of eight downgradient water-quality samples were collected from wells A023A, B001, B002, B003, and two surface-water samples from an airport drainage channel (site 34) near Womens Bay. The quality of water in the drainage channel is influenced by the bay's brackish water; specific conductance of water was $19,900 \mu \mathrm{S} / \mathrm{cm}$ on February 24, 1989 when discharge was estimated to be $0.03 \mathrm{ft}^{3} / \mathrm{s}$. Water levels in well B001, completed in bedrock, ranged from 15.1 to $22 \mathrm{ft}$ below land surface. Water levels in wells A023A, B002, and B003 that were completed in unconsolidated sediments were 9.14-11.82, 38.33-38.97, and $28.18-28.99 \mathrm{ft}$, respectively, below land surface.

The following is a list of selected constituents detected in water from four wells and a stream. No constituents had concentrations that exceeded the MCL's for drinking water.

\begin{tabular}{|c|c|c|c|}
\hline Constituent & $\begin{array}{l}\text { CAS } \\
\text { number }\end{array}$ & MCLG & $\begin{array}{l}\text { Sites having at least one concentration } \\
\text { greater than or equal to the MCLG }\end{array}$ \\
\hline \multicolumn{4}{|c|}{ INORGANIC CONSTITUENTS $(\mathrm{mg} / \mathrm{L})$} \\
\hline $\begin{array}{l}\text { Arsenic } \\
\text { Lead } \\
\text { Thallium }\end{array}$ & $\begin{array}{l}7440382 \\
7439921 \\
7440280\end{array}$ & $\begin{array}{ll}0 . & 0.05 \\
0 . & 0.005 \\
0.0005 & 0.002\end{array}$ & $\begin{array}{l}\text { B001 } \\
\text { A023A } \\
\text { Surface-water site } 34\end{array}$ \\
\hline \multicolumn{4}{|c|}{$\begin{array}{l}\text { ORGANIC CONSTITUENTS }(\mu \mathrm{g} / \mathrm{L}) \\
1,2 \text {-Dichloro- }\end{array}$} \\
\hline constituent & $\begin{array}{l}\text { CAS } \\
\text { number }\end{array}$ & $\begin{array}{l}\text { SMCL } \\
(\mathrm{mg} / \mathrm{L})\end{array}$ & $\begin{array}{l}\text { Sites having at least one concentration } \\
\text { greater than or equal to the SMCL }\end{array}$ \\
\hline $\begin{array}{l}\text { Aluminum } \\
\text { Iron } \\
\text { Manganese }\end{array}$ & $\begin{array}{l}7429905 \\
7439896 \\
7439965\end{array}$ & $\begin{array}{l}0.05 \\
0.3 \\
0.05\end{array}$ & $\begin{array}{l}\mathrm{A} 023 \mathrm{~A}, \mathrm{~B} 003 \\
\mathrm{~A} 023 \mathrm{~A} \\
\mathrm{~B} 001, \mathrm{~B} 002, \mathrm{~B} 003\end{array}$ \\
\hline
\end{tabular}

The following selected constituents do not have MCLG's or SMCL's but were detected in water samples:

\begin{tabular}{lcl}
\hline Constituent & CAS number & Sites having constituent detected at least once \\
\hline Chloromethane & 74873 & B001 \\
Trichlorofluoromethane & 75694 & B002; Surface-water site 34 \\
\hline
\end{tabular}

Lead was detected in all soil samples and ranged from $8 \mathrm{mg} / \mathrm{kg}$ (B003-13.5) to $100 \mathrm{mg} / \mathrm{L}$ (B013-00). Concentrations of TPH as high as $38,100 \mathrm{mg} / \mathrm{kg}$ were found in soil from the burn pit (B013). Toluene was also detected in the soil sample from B013 at a concentration of $0.28 \mathrm{mg} / \mathrm{kg}$. Organic constituents detected in ground water include chloromethane $(3.3 \mu \mathrm{g} / \mathrm{L}$ from B001), trichlorofluoromethane (27 $\mu \mathrm{g} / \mathrm{L}$ from B002), and toluene $(6.5 \mu \mathrm{g} / \mathrm{L}$ from B001). Trichlorofluoromethane and 1,2-dichloroethane were also detected at concentrations less than $1 \mu \mathrm{g} / \mathrm{L}$ in water from a stream (site 34). 


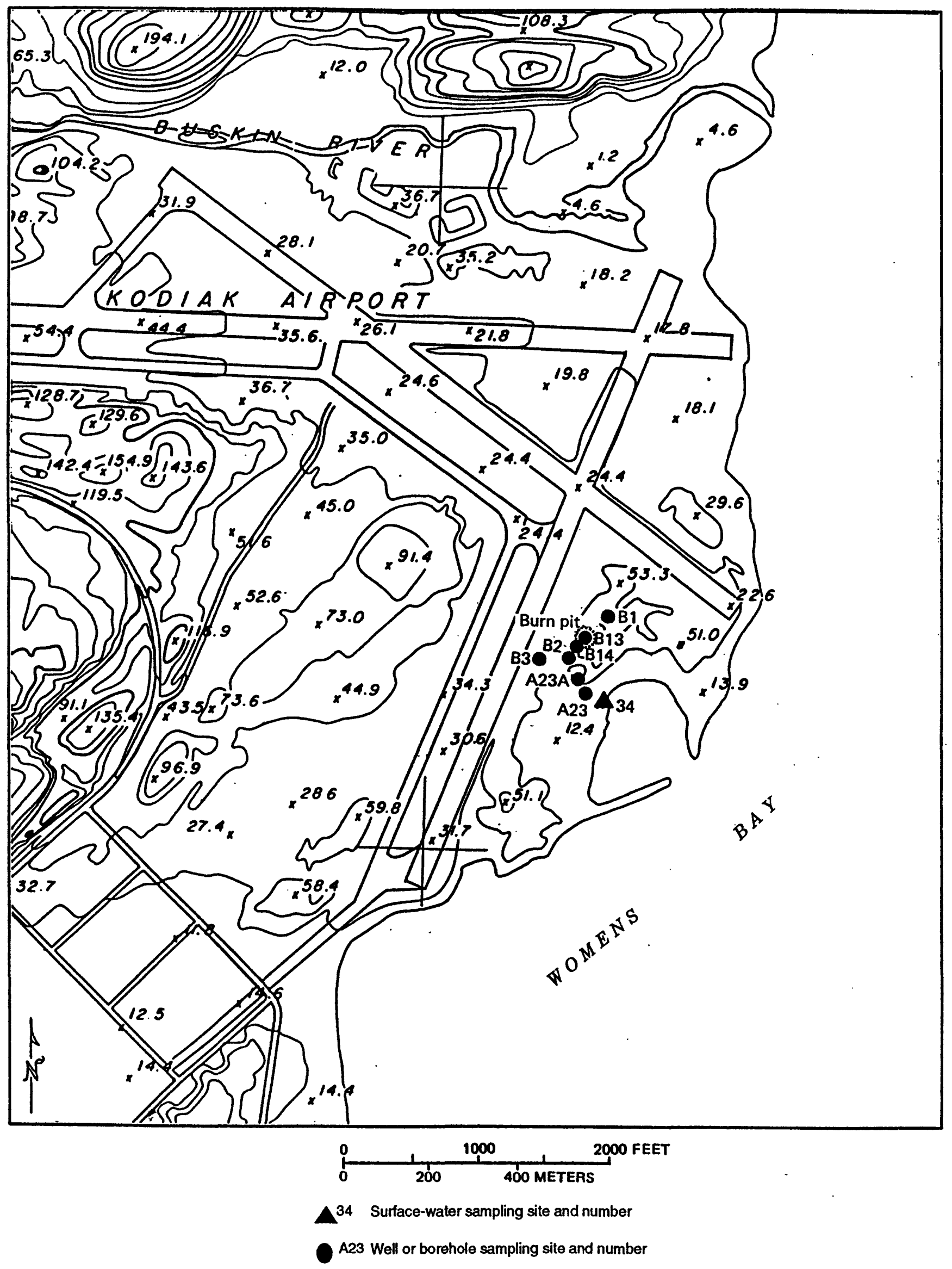

Figure 8. Area 5, a former fire-fighting training area. 


\section{Area 6. Fuel Storage Areas on Nyman Peninsula}

Area 6 (fig. 9), where fuels and lubricants have been stored since the early 1940's, is in the hills of the central Nyman Peninsula. Distribution lines and numerous large fuel-storage tanks, some with capacities as large as 40,000 gal, are located in the area. Seven of these tanks currently store jet fuels, heavy oils, and waste oil. Two others are empty, except for fuel residues and water. Jet fuel, gasoline, heavy fuel oil, and waste oil may have leaked into the nearby soils because petroleum products have been detected in ditches and excavations along the hillsides and in water in Womens Bay. Area 6 also includes storage sites for aviation gasoline, fuel, and non-fuel chemicals (Areas 7, 9, and 17), batteries (Area 8), gasoline, and waste oils. Storage tanks in an area referred to as "Mogas" (on a hill near the southwestern end of the peninsula) once were used to store gasoline and aviation gasoline. These tanks now are used to store waste oil. Downslope oil seeps are evident south of this site. Bedrock is exposed in the area or is covered by as much as $12 \mathrm{ft}$ of gravel fill, glacial till, or soil. Lenses of sand or gravel are present above and within the till.

One well (A068A) was drilled upgradient of the fuel storage areas. Forty-eight wells were drilled downgradient: A025, A026, A027, A028, A034, A035, A036, A037, A038, A041, A042, A043, A044, A045, A046, A047, A048, A049, A050, A051, A052, A053, A054, A055, A056, A057, A058, A059, A060, A061, A062, A063, A064, A065, A066A, A067, A069, A070, A074, A075, A076, A084, A085, A086, B007, B010, B011, and B012. However, wells A074 and A076 did not yield sufficient quantities of water and water-quality samples were not recovered from these wells. One upgradient and 52 downgradient soil samples were chemically analyzed. Downgradient water-quality samples were also collected from 14 surface-water sites: 40, 42, 43, 44, 45, 46, 47, $48,49,50,51,52,53$, and 54 . Several of the ground-water and surface-water sites are near Womens Bay and the water quality at those sites is influenced by the bay's brackish water. Water levels in completed wells ranged from $2.1 \mathrm{ft}$ above land surface (A075) to $16.31 \mathrm{ft}$ below land surface (A061).

The reporting levels for lead in soils ranged from 0.2 to $10 \mathrm{mg} / \mathrm{kg}$. Fifty-two of the 53 soil samples had detectable concentrations of lead ranging from 0.3 to $18 \mathrm{mg} / \mathrm{kg}$. Sample A056-05 had a lead concentration which was lower than the reporting level of $<0.9 \mathrm{mg} / \mathrm{kg}$ for that sample. A soil sample from well A069 contained toluene and xylenes at $<1 \mathrm{mg} / \mathrm{kg}$. TPH's were detected in soil samples from eight locations at $50 \mathrm{mg} / \mathrm{kg}$ or greater. The highest concentration of TPH was 2,000 $\mathrm{mg} / \mathrm{kg}$ from B010-03.

The following is a list of selected constituents detected in 207 ground-water and 23 surfacewater samples downgradient from the fuel storage areas. Sites having a water sample that had a concentration greater than or equal to the MCL are listed with an asterisk. 


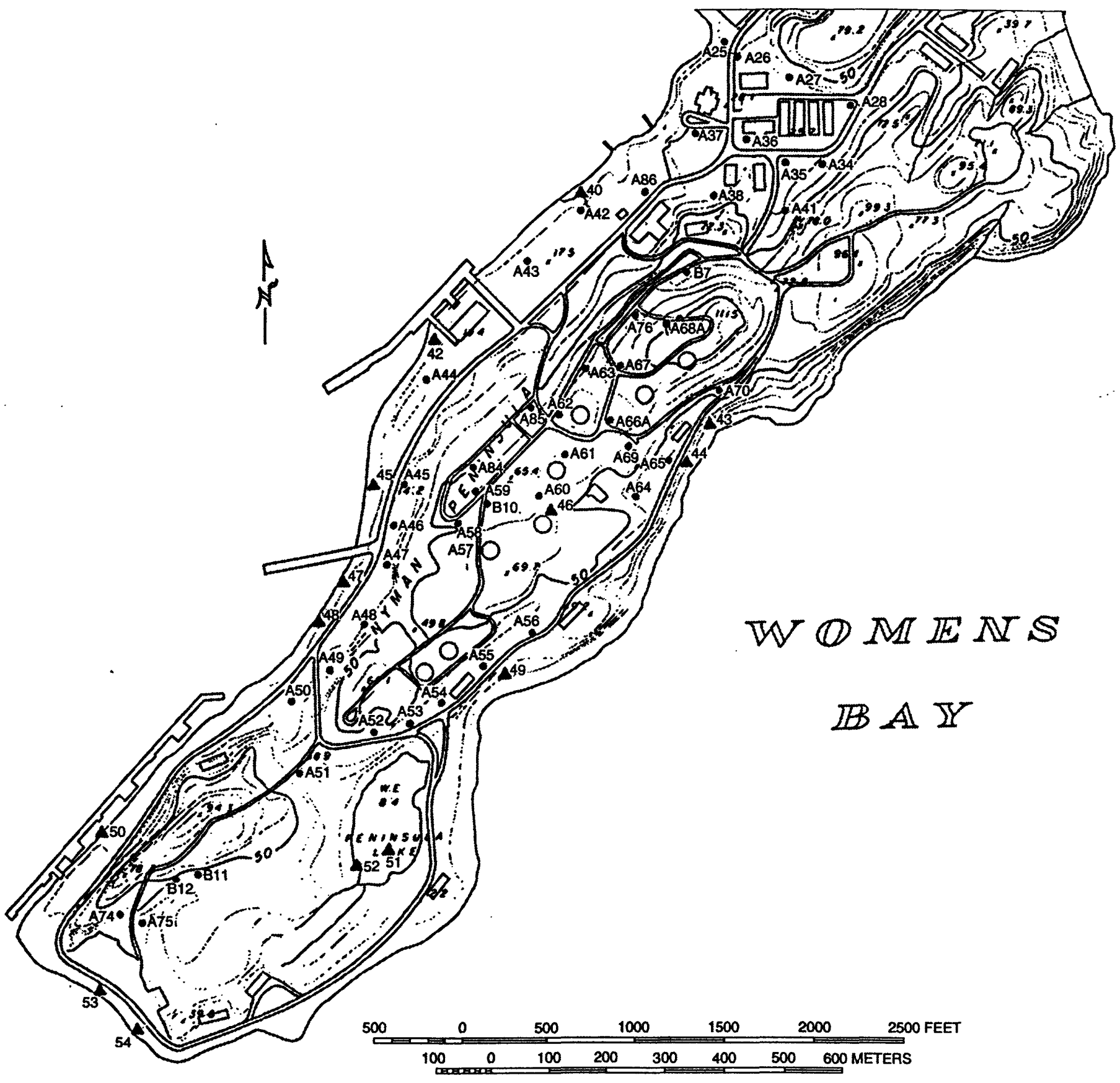

Fuel tank

49 Surface-water sampling site and number

A63 Well or borehole sampling site and number

Figure 9. Area 6, the fuel tank area on Nyman Peninsula. 


\begin{tabular}{|c|c|c|c|}
\hline Constituen & $\begin{array}{c}\text { CAS } \\
\text { at } \\
\text { number }\end{array}$ & MCLG & $\begin{array}{l}\text { Sites having at least one concentration } \\
\text { greater than or equal to the MCLG }\end{array}$ \\
\hline \multicolumn{4}{|c|}{ INORGANIC CONSTITUENTS $(\mathrm{mg} / \mathrm{L})$} \\
\hline Arsenic & 7440382 & 0.05 & $\mathrm{~A} 034, \mathrm{~A} 038, \mathrm{~A} 042, \mathrm{~A} 050, \mathrm{~A} 052, \mathrm{~A} 054, \mathrm{~A} 057, \mathrm{~A} 086, \mathrm{~B} 010$ \\
\hline Lead & 7439921 & 0.005 & $\begin{array}{l}\mathrm{A} 025 *, \mathrm{~A} 028 *, \mathrm{~A} 034 *, \mathrm{~A} 035, \mathrm{~A} 037 *, \mathrm{~A} 042, \mathrm{~A} 044^{*}, \mathrm{~A} 045, \\
\mathrm{~A} 052, \mathrm{~A} 053, \mathrm{~A} 058, \mathrm{~A} 062 *, \mathrm{~A} 065, \mathrm{~A} 067, \mathrm{~A} 069 *, \mathrm{~A} 086, \mathrm{~B} 012 \\
\text { Surface-water sites } 7,53\end{array}$ \\
\hline \multicolumn{4}{|c|}{ ORGANIC CONSTITUENTS $(\mu \mathrm{g} / \mathrm{L})$} \\
\hline $\begin{array}{l}\text { Benzene } \\
\text { Chloroform }\end{array}$ & $\begin{array}{r}71432 \\
67663\end{array}$ & 0.5 & $\begin{array}{l}\text { A050, A060*, A069* } \\
\text { A035, A044, A051, A053, A056, A064, A066A, A067, A085; } \\
\text { Surface-water sites } 40,52\end{array}$ \\
\hline $\begin{array}{l}\text { 1.2-Dichlo } \\
\text { ethane }\end{array}$ & 107062 & 0 . & $\begin{array}{l}\mathrm{A} 025, \mathrm{~A} 26, \mathrm{~A} 027, \mathrm{~A} 028, \mathrm{~A} 034, \mathrm{~A} 035, \mathrm{~A} 036, \mathrm{~A} 037, \mathrm{A038}, \mathrm{A041}, \mathrm{A} 042, \mathrm{~A} 043, \mathrm{~A} 044, \mathrm{~A} 045, \\
\mathrm{~A} 046, \mathrm{~A} 050, \mathrm{~A} 051, \mathrm{~A} 052, \mathrm{~A} 055, \mathrm{~A} 056, \mathrm{~A} 057, \mathrm{~A} 058, \mathrm{~A} 060, \mathrm{~A} 064, \mathrm{~A} 065, \mathrm{~A} 069, \mathrm{~A} 084, \\
\mathrm{~A} 085, \mathrm{~A} 086 \text {; Surface-water sites } 40,43,44,45,47,49,53\end{array}$ \\
\hline $\begin{array}{l}\text { Methylene } \\
\text { chloride }\end{array}$ & 750920 & - & A085; Surface-water site 43 \\
\hline $\begin{array}{l}\text { Tetrachlor } \\
\text { ethene }\end{array}$ & 127184 & 5. & A084 \\
\hline $\begin{array}{l}\text { Trichloro- } \\
\text { ethene }\end{array}$ & 79016 & 5 . & A084 \\
\hline Constituen & $\begin{array}{c}\text { CAS } \\
\text { number }\end{array}$ & $\begin{array}{l}\text { SMCL } \\
(\mathrm{mg} / \mathrm{L})\end{array}$ & $\begin{array}{l}\text { Sites having at least one concentration } \\
\text { greater than or equal to the SMCL }\end{array}$ \\
\hline Aluminum & 7429905 & 0.05 & $\begin{array}{l}\mathrm{A} 026, \mathrm{~A} 028, \mathrm{~A} 035, \mathrm{~A} 042, \mathrm{~A} 044, \mathrm{~A} 047, \mathrm{~A} 048, \mathrm{~A} 051, \mathrm{~A} 052, \mathrm{~A} 058, \mathrm{~A} 060, \mathrm{~A} 062, \mathrm{~A} 063, \\
\mathrm{~A} 064, \mathrm{~A} 067, \mathrm{~A} 084, \mathrm{~A} 085, \mathrm{~A} 086, \mathrm{~B} 007, \mathrm{~B} 010\end{array}$ \\
\hline Chloride & 1003 & 250 & A044, A050, A086 \\
\hline Iron & 7439896 & 0.3 & $\begin{array}{l}\mathrm{A} 026, \mathrm{~A} 027, \mathrm{~A} 034, \mathrm{~A} 035, \mathrm{~A} 038, \mathrm{~A} 050, \mathrm{~A} 052, \mathrm{~A} 054, \mathrm{~A} 055, \mathrm{~A} 057, \mathrm{~A} 060, \mathrm{~A} 063, \mathrm{~A} 064 \\
\mathrm{~A} 065, \mathrm{~A} 086, \mathrm{~B} 010\end{array}$ \\
\hline Manganese & 7439965 & 0.05 & $\begin{array}{l}\mathrm{A} 027, \mathrm{~A} 034, \mathrm{~A} 035, \mathrm{~A} 037, \mathrm{~A} 038, \mathrm{~A} 041, \mathrm{~A} 046, \mathrm{~A} 049, \mathrm{~A} 050, \mathrm{~A} 052, \mathrm{~A} 053, \mathrm{~A} 054, \mathrm{~A} 055, \\
\mathrm{~A} 056, \mathrm{~A} 057, \mathrm{~A} 058, \mathrm{~A} 059, \mathrm{~A} 060, \mathrm{~A} 061, \mathrm{~A} 063, \mathrm{~A} 064, \mathrm{~A} 065, \mathrm{~A} 069, \mathrm{~A} 070, \mathrm{~A} 075, \mathrm{~A} 084 \\
\mathrm{~A} 085, \mathrm{~A} 086, \mathrm{~B} 007, \mathrm{~B} 010, \mathrm{~B} 011, \mathrm{~B} 012\end{array}$ \\
\hline
\end{tabular}

The following selected constituents do not have MCLG's or SMCL's but were detected in water samples:

\begin{tabular}{lcc}
\hline Constituent & CAS number & Sites having constituent detected at least once \\
\hline Total petroleum hydrocarbons & 5289290400 & $\begin{array}{l}\text { A026, A027, A034, A041, A043, A045, A053, A066A, A067, A069, } \\
\text { B007, B010, B011 } \\
\text { Surface-water site 42 }\end{array}$ \\
\hline
\end{tabular}

Some of the organic constituents detected in ground water include benzene, toluene, ethylbenzene, xylenes, chloroform and 1,2-dichloroethane. The highest concentrations observed were the following: $17 \mu \mathrm{g} / \mathrm{L}$ benzene from A060;15 $\mu \mathrm{g} / \mathrm{L}$ toluene from A069;33 $\mu \mathrm{g} / \mathrm{L}$ ethylbenzene from $A 069 ; 33 \mu \mathrm{g} / \mathrm{L}$ m-xylene and $140 \mu \mathrm{g} / \mathrm{L}$ o- $\&$ p-xylenes from $A 060 ; 31 \mu \mathrm{g} / \mathrm{L}$ chloroform from $\mathrm{A} 067$; and $1.9 \mu \mathrm{g} / \mathrm{L}$ 1,2-dichloroethane from A043. Surface-water samples had few organic constituents at concentrations above reporting levels. Benzene, ethylbenzene, and xylenes were not detected in any surface-water samples. The highest concentrations of toluene and chloroform detected in surface water were 0.3 and $5.5 \mu \mathrm{g} / \mathrm{L}$, respectively, from site 40 . 


\section{Area 7. Former Drum Storage Areas on Nyman Peninsula}

Area 7 (fig. 10) consists of two former drum storage areas on the hills of Nyman Peninsula that may have been used by the Navy and USCG since the early 1940's. A 1986 USCG inventory of barrels and drums in Area 7 revealed the presence of solvents, degreasers, tetrachloroethylene, carbon tetrachloride, methylene chloride, 1,1,1-trichloroethane, trichloroethylene, and bags of absorbent materials that had been used to clean up petroleum-product spills. Much of the ground surface in the storage area is stained, indicating that products may have leaked or spilled. In 1986, the contents of numerous barrels and drums were poured into storage tanks in the Mogas area. Most containers were removed from the site by June 1990. Bedrock at these sites is typically covered with 10 to $15 \mathrm{ft}$ of gravel fill, glacial till, or soil. The till consists of poorly sorted clay, silt, sand, and gravel that becomes more compacted with depth.

Although well A066A is downgradient from the fuel storage tanks in Area 6, it is considered to be upgradient from the drum storage areas in Area 7. Fourteen wells were considered downgradient: A045, A046, A057, A058, A059, A060, A061, A064, A065, A069, A084, B008, B009, and B010; however, B009 yielded no water. Four upgradient and 47 downgradient ground-water samples were analyzed. One upgradient and 17 downgradient soil samples were chemically analyzed. Downgradient water-quality samples were also collected from two surface-water sites. One sample was collected from site 42 and two samples were collected from site 44 . Discharges at sites 42 and 44 were less than or equal to $0.01 \mathrm{ft}^{3} / \mathrm{s}$. Water levels in completed wells ranged from $0.11 \mathrm{ft}$ (A084) to $16.31 \mathrm{ft}$ (A061) below land surface.

All soil samples had detectable concentrations of lead ranging from $0.4 \mathrm{mg} / \mathrm{kg}$ (A058-05) to $14 \mathrm{mg} / \mathrm{kg}$ (A069-05). A069-05 contained toluene and m-xylene (0.67 and $0.28 \mathrm{mg} / \mathrm{kg})$. TPH was detected in near-surface soil samples A069-05 (100 mg/kg), B009-03 (300 mg/kg), and B010-03 $(2,000 \mathrm{mg} / \mathrm{kg})$. However, concentrations of TPH were lower than reporting levels $(50 \mathrm{mg} / \mathrm{kg})$ at depths of $7 \mathrm{ft}$ at sites B009 and B010.

The following is a list of selected constituents detected in water samples near the former drum storage areas. Sites having a water sample that had one or more concentrations greater than or equal to the MCL's are listed with an asterisk. 


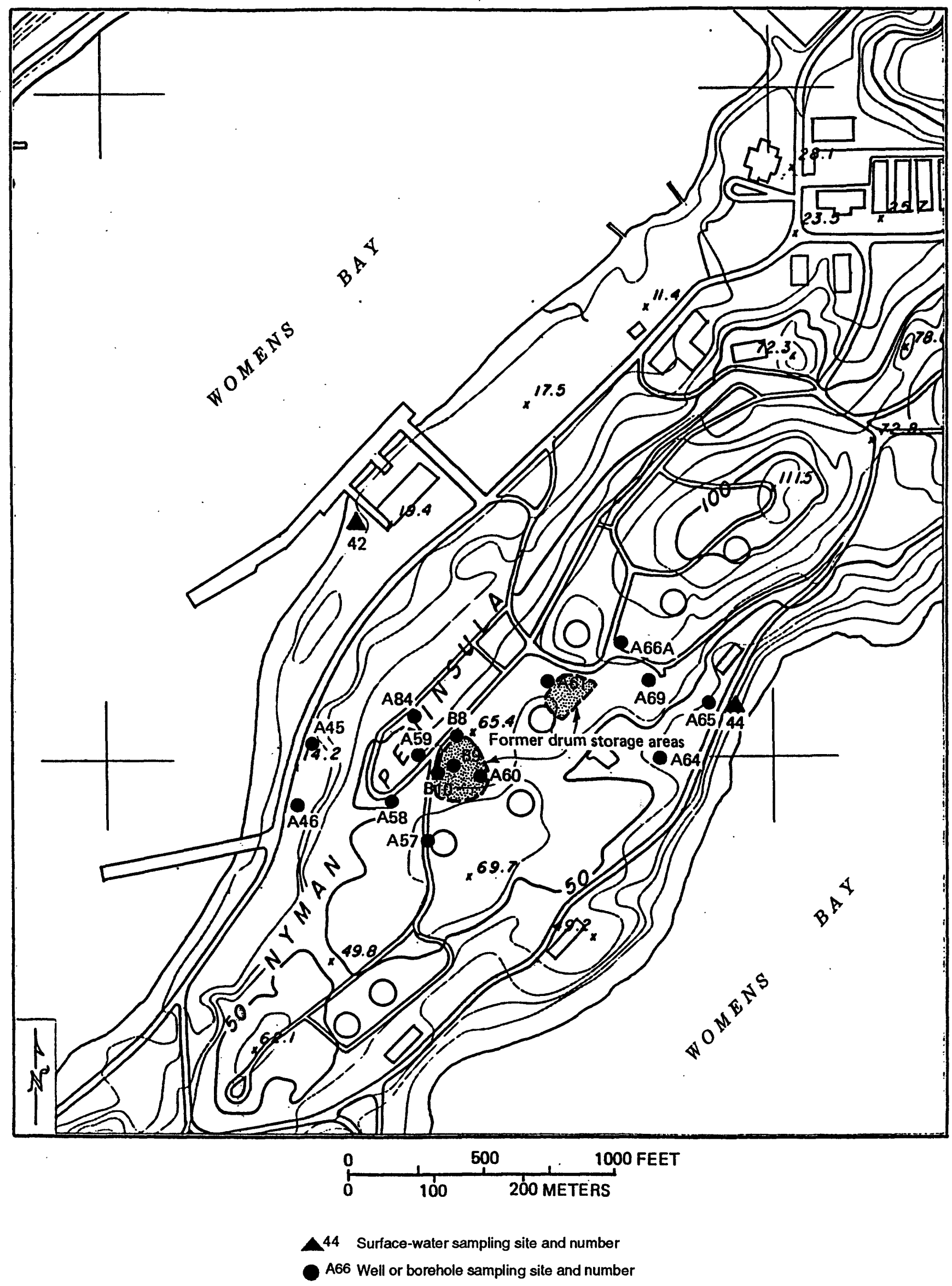

Figure 10. Area 7, former drum storage areas on Nyman Peninsula. 


\begin{tabular}{|c|c|c|c|}
\hline Constituent & $\begin{array}{l}\text { CAS } \\
\text { number }\end{array}$ & MCLG & $\begin{array}{l}\text { Sites having at least one concentration } \\
\text { greater than or equal to the MCLG }\end{array}$ \\
\hline \multicolumn{4}{|c|}{ INORGANIC CONSTITUENTS (mg/L) } \\
\hline Arsenic & 7440382 & $0 . \quad 0.05$ & $\mathrm{~A} 057, \mathrm{~B} 008, \mathrm{~B} 010$ \\
\hline Lead & 7439921 & 0.005 & $\mathrm{~A} 045, \mathrm{~A} 058, \mathrm{~A} 059^{*}, \mathrm{~A} 065, \mathrm{~A} 069^{*}$ \\
\hline \multicolumn{4}{|c|}{ SRGANIC CONSTITUENTS $(\mu \mathrm{g} / \mathrm{L})$} \\
\hline $\begin{array}{l}\text { Benzene } \\
\text { Chloroform }\end{array}$ & $\begin{array}{l}71432 \\
67663\end{array}$ & $\begin{array}{rr}0 . & 5 . \\
0 . & 100 .\end{array}$ & $\begin{array}{l}\text { A060*, A069* } \\
\text { A064, A066A }\end{array}$ \\
\hline \multicolumn{4}{|c|}{$\begin{array}{l}\text { Cniorororm } \\
1,2 \text {-Dichloro- }\end{array}$} \\
\hline ethane & 107062 & 0 . & $\begin{array}{l}\text { A045, A046, A057, A058, A059, A060, A064, A065, A069, A084; } \\
\text { Surface-water site } 44\end{array}$ \\
\hline \multicolumn{4}{|l|}{ Tetrachloro- } \\
\hline \multirow{2}{*}{$\begin{array}{l}\text { ethene } \\
\text { Trichloro- } \\
\text { ethene }\end{array}$} & 127184 & 5 . & A084 \\
\hline & 79016 & 5. & A084 \\
\hline Aluminum & 7429905 & 0.05 & $\mathrm{~A} 058, \mathrm{~A} 059, \mathrm{~A} 060, \mathrm{A064}, \mathrm{A084}, \mathrm{B} 010$ \\
\hline Iron & 7439896 & 0.3 & $\mathrm{~A} 057, \mathrm{~A} 060, \mathrm{~A} 064, \mathrm{~A} 065, \mathrm{~B} 008, \mathrm{~B} 010$ \\
\hline Manganese & 7439965 & 0.05 & $\begin{array}{l}\mathrm{A} 046, \mathrm{~A} 057, \mathrm{~A} 058, \mathrm{~A} 059, \mathrm{~A} 060, \mathrm{~A} 061, \mathrm{~A} 064, \mathrm{~A} 065, \mathrm{~A} 069, \mathrm{~A} 084, \\
\mathrm{~B} 008, \mathrm{~B} 010\end{array}$ \\
\hline
\end{tabular}

The following selected constituents do not have MCLG's or SMCL's but were detected in water samples:

\begin{tabular}{lcl}
\hline Constituent & CAS number & Sites having constituent detected at least once \\
\hline Total Petroleum Hydrocarbons & 5289290400 & A045, A066A, A069, B010 \\
bis(2-Ethylhexyl)phthalate & 117817 & Surface-water site 42 \\
m-xylene & 108383 & A060, A069 \\
o- \& p-xylenes & 816700 & A060, A069 \\
\hline
\end{tabular}

Well A069 yielded water having the highest dissolved lead concentration at the Center, 0.019-0.11 mg/L. Water from A069 also contained benzene at concentrations ranging from $<0.7$ to $8.3 \mu \mathrm{g} / \mathrm{L}$. Well A060 yielded water having benzene concentrations from $<0.7$ to $17 \mu \mathrm{g} / \mathrm{L}$. Organic compounds detected in surface water were 1,2 -dichloroethane $(0.82 \mu \mathrm{g} / \mathrm{L}$ from site 44$)$ and bis $(2$ ethylhexyl)phthalate $(17 \mu \mathrm{g} / \mathrm{L}$ from site 42$)$. 


\section{Area 8. Battery Storage Areas on Nyman Peninsula}

Area 8 (fig. 11) consists of two battery storage areas on Nyman Peninsula. Batteries currently are stored only on a concrete pad near well A045. The battery storage area northeast of well A084 is not being used at the present time. Bedrock at these sites is typically mantled by gravel fill, glacial till, sand, or soil. The till consists of poorly sorted clay, silt, sand, and gravel that becomes more compacted with depth.

Well A084 is considered upgradient from the battery storage areas, but this site is downgradient from fuel tanks discussed in Area 6 and from drum-storage sites discussed in Area 7. One soil and four water samples were collected from A084. Water levels in well A084 ranged from 0.96 to $4.60 \mathrm{ft}$ below land surface. Three wells were considered downgradient (A044, A045, and A046), and a total of 3 downgradient soil and 12 downgradient ground-water samples were collected. These wells are near Womens Bay and their water quality is influenced by the bay's brackish water. The specific conductance of water from A044 was as high as $9,910 \mu \mathrm{S} / \mathrm{cm}$. Water levels in wells ranged from 1.95 to $12.73 \mathrm{ft}$ below land surface in well $A 044,0.29$ to $3.99 \mathrm{ft}$ in well A045, and 0.62 to $4.25 \mathrm{ft}$ in well A046. One downgradient water-quality sample was also collected from a drainage channel near Womens Bay (surface-water site 42). Discharge at site 42 on October 9 , 1988 , was estimated to be $0.01 \mathrm{ft}^{3} / \mathrm{s}$ and its specific conductance was $55 \mu \mathrm{S} / \mathrm{cm}$.

The following is a list of selected constituents detected in water from four wells and a stream near the battery storage areas. Sites listed with an asterisk indicate that a concentration equaled or exceeded the MCL's for drinking water.

\begin{tabular}{|c|c|c|c|}
\hline Constituent & $\begin{array}{l}\text { CAS } \\
\text { number }\end{array}$ & MCLG & $\begin{array}{l}\text { Sites having at least one concentration } \\
\text { greater than or equal to the MCLG }\end{array}$ \\
\hline \multicolumn{4}{|c|}{ INORGANIC CONSTITUENTS (mg/L) } \\
\hline Lead & 7439921 & 0.005 & $\mathrm{~A} 044 *, \mathrm{~A} 045$ \\
\hline \multicolumn{4}{|c|}{ ORGANIC CONSITUENTS $\mu \mathrm{g} / \mathrm{L})$} \\
\hline \multicolumn{4}{|c|}{ 1,2-Dichloro- } \\
\hline $\begin{array}{l}\text { ethane } \\
\text { Chloroform }\end{array}$ & $\begin{array}{r}107062 \\
67663\end{array}$ & $\begin{array}{rr}0 . & 5 . \\
0 . & 100 .\end{array}$ & $\begin{array}{l}\mathrm{A} 044, \mathrm{~A} 045, \mathrm{~A} 046, \mathrm{~A} 084 \\
\mathrm{~A} 044\end{array}$ \\
\hline \multirow{3}{*}{$\begin{array}{l}\text { Tetrachloro- } \\
\text { ethene } \\
\text { Trichloro- } \\
\text { ethene }\end{array}$} & & & \\
\hline & 127184 & 5. & A084 \\
\hline & 79016 & 5 . & A084 \\
\hline Constituent & $\begin{array}{l}\text { CAS } \\
\text { number }\end{array}$ & $\begin{array}{l}\text { SMCL } \\
(\mathrm{mg} / \mathrm{L})\end{array}$ & $\begin{array}{l}\text { Sites having at least one concentration } \\
\text { greater than or equal to the SMCL }\end{array}$ \\
\hline Manganese & 7439965 & 0.05 & $\mathrm{~A} 046, \mathrm{~A} 084$ \\
\hline
\end{tabular}

The following selected constituents do not have MCLGs or SMCLs but were detected in water samples recovered in Area 8:

\begin{tabular}{lrr}
\hline Constituent & CAS number & Sites having constituent detected at least once \\
\hline Total petroleum hydrocarbons & 5289290400 & A045 \\
bis (2-Ethylhexy l) phthalate & 117817 & Surface-water site 42 \\
\hline
\end{tabular}




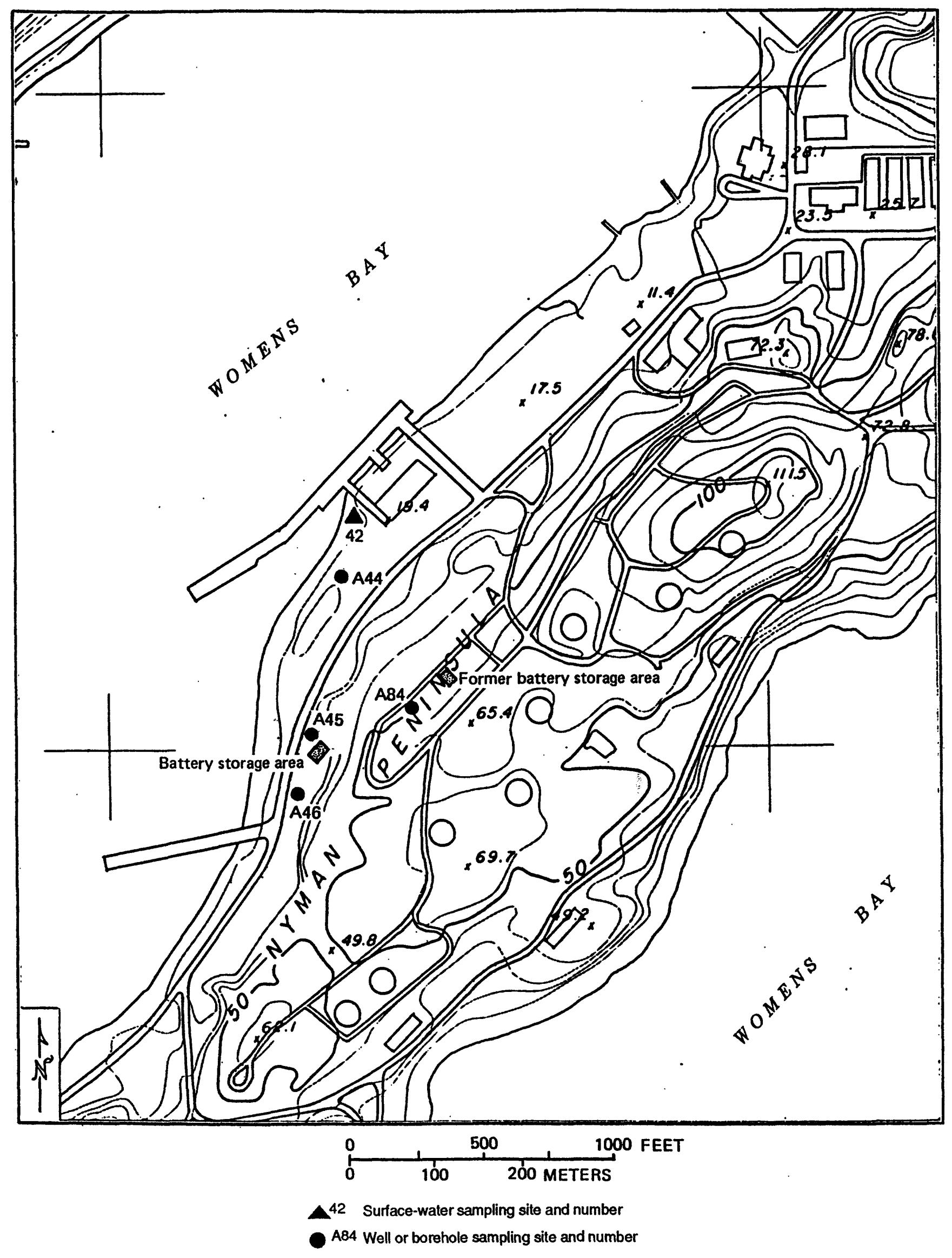

Figure 11. Area 8, the battery storage areas on Nyman Peninsula. 
Contaminants from batteries may lead to soils and waters having low $\mathrm{pH}$ and high concentrations of lead and mercury. Soils were not analyzed for mercury content, but soil samples had concentrations of lead ranging from 7.2 to $15 \mathrm{mg} / \mathrm{kg}$. Soil sample A044-05 had a detectable concentration of TPH, but TPH's were not detected in sample A044-20.

The lowest $\mathrm{pH}$ values were observed in water from the upgradient well, A084, and ranged from 5.8 to 6.4 units. $\mathrm{pH}$ values in waters from downgradient wells ranged from 6.0 to 6.4 in A044, 7.2 to 7.6 in A045, and 7.4 to 7.6 in A046. Dissolved lead concentrations in water from A044 ranged from $<0.004$ to $0.005 \mathrm{mg} / \mathrm{L}$ and from $\mathrm{A} 045$ ranged from $<0.002$ to $0.004 \mathrm{mg} / \mathrm{L}$. Mercury concentrations in waters from all wells were less than $0.0001 \mathrm{mg} / \mathrm{L}$. 


\section{Area 9. Former Aviation Gasoline Storage Area on Nyman Peninsula}

Area 9 consists of four sites near the northeastern end of Nyman Peninsula (fig. 12) where aviation gasoline was stored in drums and in storage tanks as large as 25,000 gal. Each site is on or near the crest of a hill and all tanks and drums have been removed. Bedrock at these sites is typically covered by gravel fill, glacial till, sand, or soil. The till consists of poorly sorted clay, silt, sand, and gravel that becomes more compacted with depth.

No wells were drilled upgradient from the former aviation gasoline storage sites. The following 10 wells were drilled downgradient: A029, A030, A032, A032A, A033, A034, A041, A071, $\mathrm{A} 072$, and A073. A well was also drilled at site A031, but the well was dry and no water samples were collected. Water levels in completed wells ranged from $0.54 \mathrm{ft}$ above land surface (A032A) to $17.61 \mathrm{ft}$ below land surface (A071). A total of 34 ground-water samples were analyzed. Nine downgradient soil samples were chemically analyzed. Downgradient water-quality samples were also collected from surface-water sites 37, 39, and 41. Two samples each were collected from sites 37 and 39 and one sample was collected from site 41 . Measured discharges ranged from 0 to $0.04 \mathrm{ft}^{3} / \mathrm{s}$.

All soil samples had detectable concentrations of lead ranging from $0.6 \mathrm{mg} / \mathrm{kg}$ (A034-05) to $25 \mathrm{mg} / \mathrm{kg}$ (A032A-03). A soil sample from A073-05 had detectable concentrations of trichloroethene $(0.15 \mathrm{mg} / \mathrm{kg})$ and tetrachloroethene $(0.41 \mathrm{mg} / \mathrm{kg})$. A sample from well A032A-03 contained o- \& p-xylenes $(0.3 \mathrm{mg} / \mathrm{kg}$ ) and samples from A029-05 and A034-05 contained TPH (170 and $60 \mathrm{mg} / \mathrm{kg}$ respectively).

The following is a list of selected constituents detected in water in wells and streams near the aviation gasoline storage areas. Sites listed with an asterisk indicate that a concentration equaled or exceeded the MCL for drinking water.

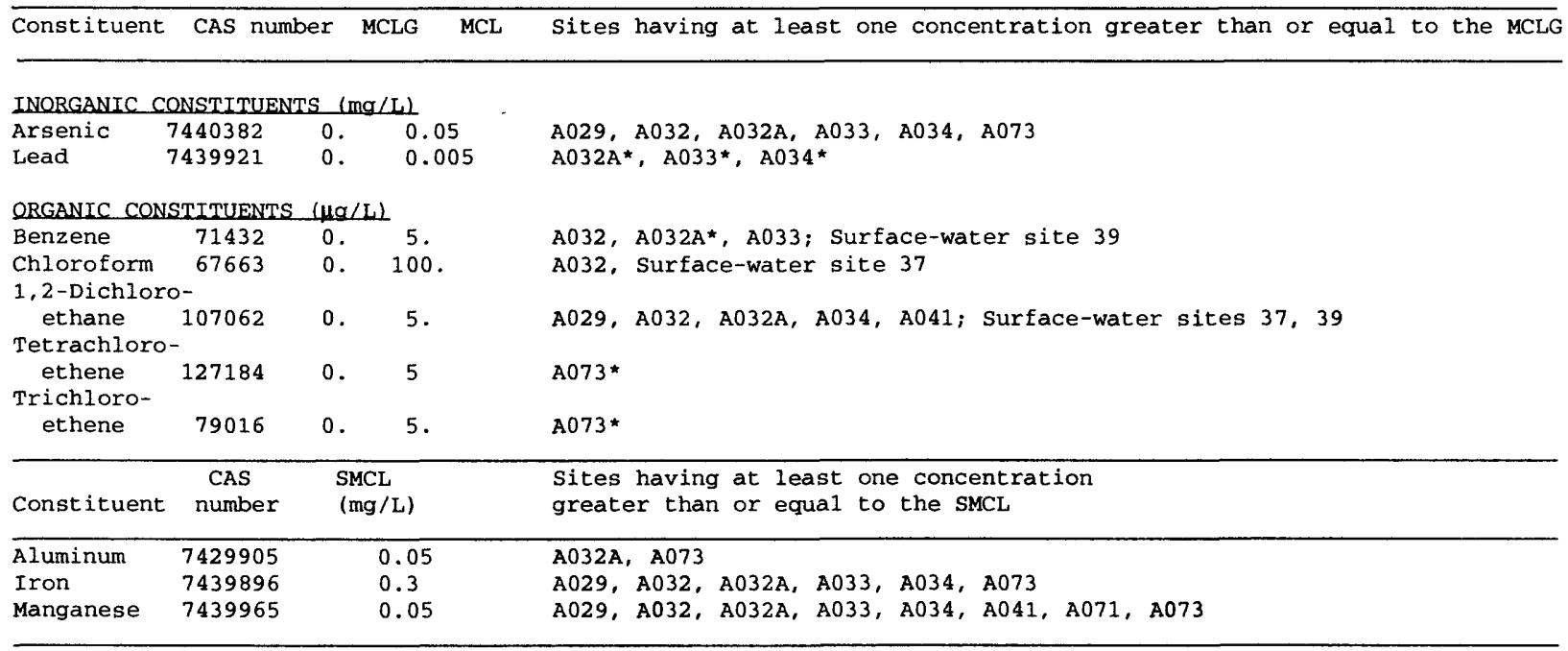

The following selected constituents do not have MCLG's or SMCL's but were detected in water samples:

\begin{tabular}{lll}
\hline Constituent & CAS number & Sites having constituent detected at least once \\
\hline Total petroleum hydrocarbons & 5289290400 & A030, A032A, A034, A041, A071
\end{tabular}

Well A032A yielded water containing up to $0.02 \mathrm{mg} / \mathrm{L}$ dissolved lead, $15 \mu \mathrm{g} / \mathrm{L}$ benzene, $76 \mu \mathrm{g} / \mathrm{L}$ toluene, $250 \mu \mathrm{g} / \mathrm{L}$ ethylbenzene, $150 \mu \mathrm{g} / \mathrm{L}$ m-xylene, and $150 \mu \mathrm{g} / \mathrm{L} \mathrm{o}-\&$ p-xylenes. Well A073 yielded water having trichloroethene and tetrachloroethene concentrations as high as 66 and $20 \mu \mathrm{g} / \mathrm{L}$, respectively. Water from surface-water site 39 contained benzene at $<0.2$ and $2.2 \mu \mathrm{g} / \mathrm{L}$ and ethylbenzene at $<0.2$ and $3.1 \mu \mathrm{g} / \mathrm{L}$. 


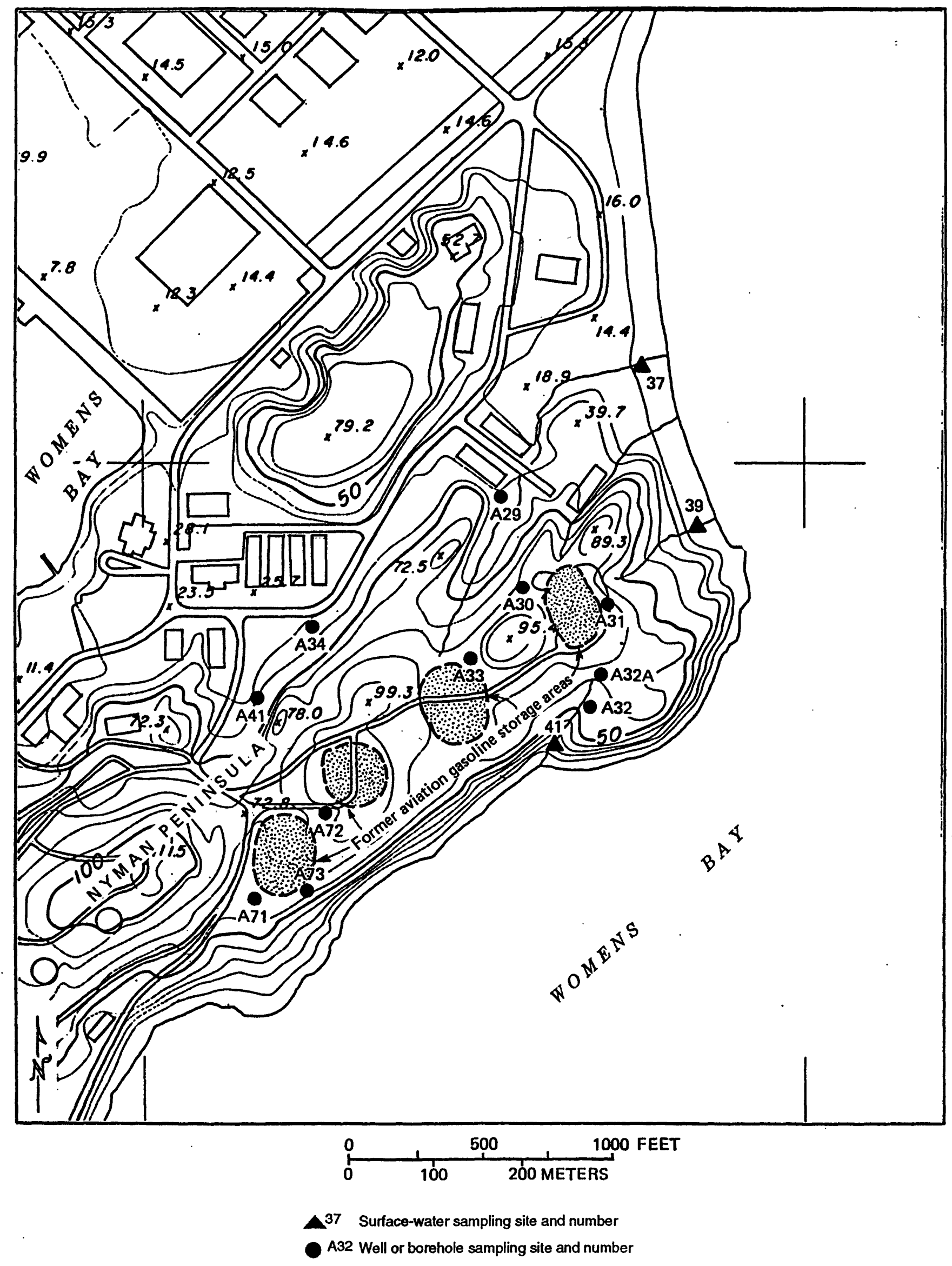

Figure 12. Area 9, the former aviation gasoline storage area on Nyman Peninsula. 


\section{Area 10. Air Station}

Aircraft are maintained, fueled, and parked in Area 10 (fig. 13), and underground fuel-distribution lines have been installed throughout the area. Upgradient areas south of the air station are places where oils, lubricants, and aviation gasoline are or have been stored. Most low-lying areas are covered with asphalt taxiways and parking aprons. Gravel fill, glacial till, and sand underlie the asphalt and are the surficial sediments in upland areas. In 1987, approximately 150,000 gal of jet fuel leaked from an above-ground storage tank on the southeastern side of the area.

No wells were drilled upgradient from the air station. Five wells were drilled downgradient from fuel and aircraft storage areas: A014, A018, A021, A021A, and A025; however, well A021 was destroyed shortly after it was constructed. Sixteen ground-water samples were collected. Water levels in completed wells ranged from $5.27 \mathrm{ft}$ (A025) to $35.73 \mathrm{ft}$ (A014) below land surface. Soil samples from A014, A018, A021, and A021A were chemically analyzed. Two downgradient water-quality samples were also collected from surface-water site 38 .

All soil samples had detectable concentrations of lead ranging from $5.2 \mathrm{mg} / \mathrm{kg}$ (A018-09) to $12 \mathrm{mg} / \mathrm{kg}$ (A025-05). A soil sample from A021-09 contained $360 \mathrm{mg} / \mathrm{kg} \mathrm{TPH}$.

The following is a list of selected constituents detected in water in four wells and a stream near the air station. Sites listed with an asterisk indicate that a concentration equaled or exceeded the MCL for drinking water.

\begin{tabular}{|c|c|c|c|}
\hline Constituent & $\begin{array}{l}\text { CAS } \\
\text { number }\end{array}$ & MCLG & $\begin{array}{l}\text { Sites having at least one concentration } \\
\text { greater than or equal to the MCLG }\end{array}$ \\
\hline \multicolumn{4}{|c|}{ INORGANIC CONSTITUENTS (mg/L) } \\
\hline Arsenic & 7440382 & 0.05 & $\mathrm{~A} 018, \mathrm{~A} 021 \mathrm{~A}$ \\
\hline Lead & 7439921 & 0.005 & A018, A021A, A025 \\
\hline \multicolumn{4}{|c|}{ ORGANIC CONSTITUENTS $(\mu \mathrm{g} / \mathrm{L})$} \\
\hline Benzene & 71432 & 5 . & $\mathrm{A} 021 \mathrm{~A}$ * \\
\hline \multicolumn{4}{|c|}{ 1,2-Dichloro- } \\
\hline ethane & 107062 & 5 . & A014, A018, A025; Surface-water site 38 \\
\hline Constituent & $\begin{array}{l}\text { CAS } \\
\text { number }\end{array}$ & $\begin{array}{l}\text { SMCL } \\
(\mathrm{mg} / \mathrm{L})\end{array}$ & $\begin{array}{l}\text { Sites having at least one concentration } \\
\text { greater than or equal to the SMCL }\end{array}$ \\
\hline Aluminum & 7429905 & 0.05 & A021A \\
\hline Iron & 7439896 & 0.3 & A021A \\
\hline Manganese & 7439965 & 0.05 & $\mathrm{~A} 014, \mathrm{~A} 018, \mathrm{~A} 021 \mathrm{~A}$ \\
\hline
\end{tabular}

The following selected constituent does not have MCLG's or SMCL's, but was detected in water samples:

\begin{tabular}{lll}
\hline Constituent & CAS number & Sites having constituent detected at least once \\
\hline Total petroleum hydrocarbons & 5289290400 & A021A \\
\hline
\end{tabular}

A thin film, possibly a fuel product, was present on the water surface in well A021A. The well yielded water having concentrations as high as $78 \mu \mathrm{g} / \mathrm{L}$ benzene, $18 \mu \mathrm{g} / \mathrm{L}$ toluene, $140 \mu \mathrm{g} / \mathrm{L}$ ethylbenzene, $55 \mu \mathrm{g} / \mathrm{L} \mathrm{m}$-xylene, $170 \mu \mathrm{g} / \mathrm{L}$ o- \& p-xylenes, and $9.2 \mathrm{mg} / \mathrm{L} \mathrm{TPH}$. However, two sets of water samples from a nearby drainage channel (surface-water site 38 ) had concentrations of these organic compounds that were lower than detection levels. 


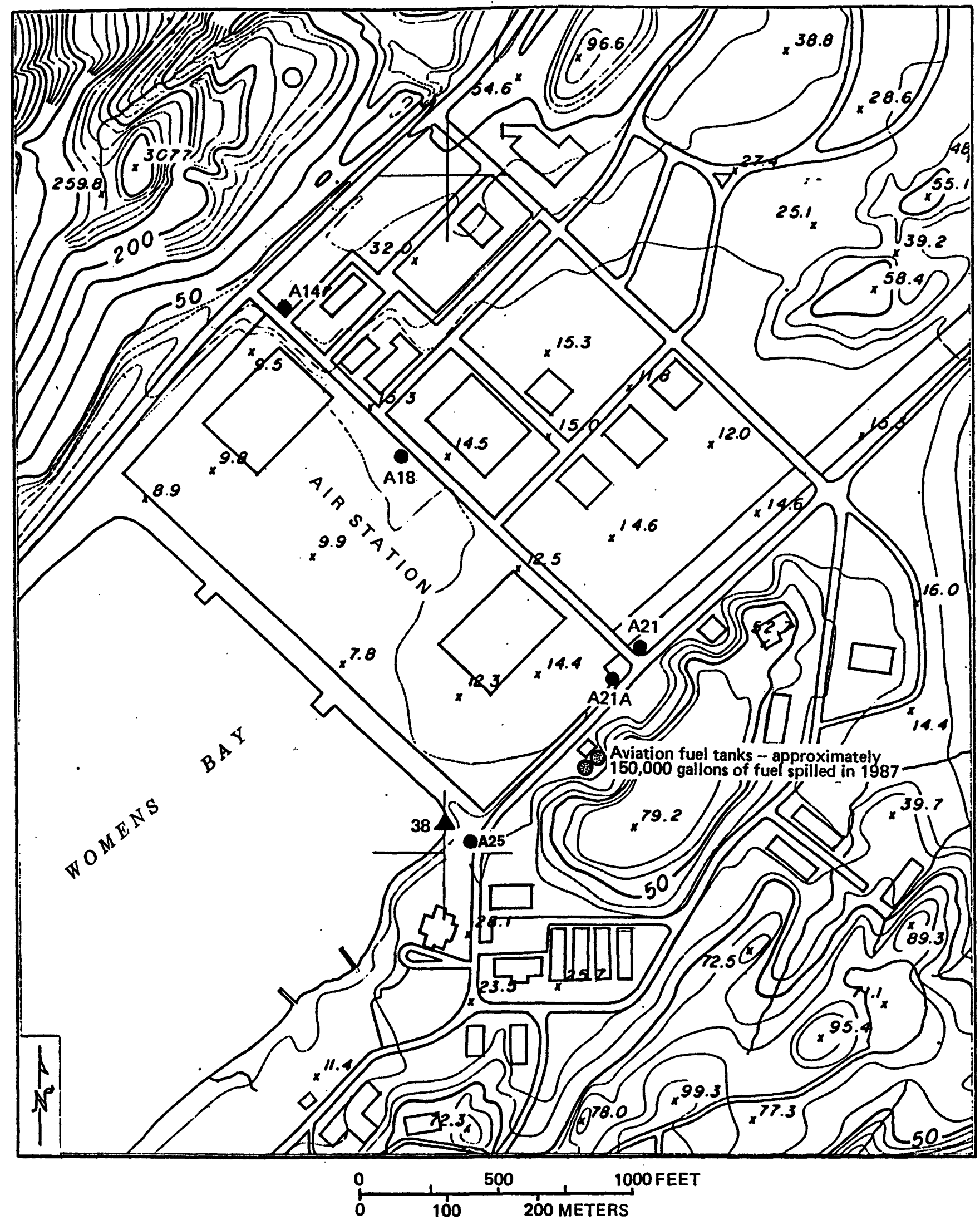

38 Surface-water sampling site and number

A21 Well or borehole sampling site and number

Figure 13. Area 10, the air station. 


\section{Area 11. Paint Plant}

An underground storage tank is in Area 11 (fig. 14). The reconnaissance soil-gas survey with an organic vapor analyzer found that organic vapors in this area did not exceed background levels; thus no test holes or wells were drilled in Area 11 and soils and surface-water were not sampled.

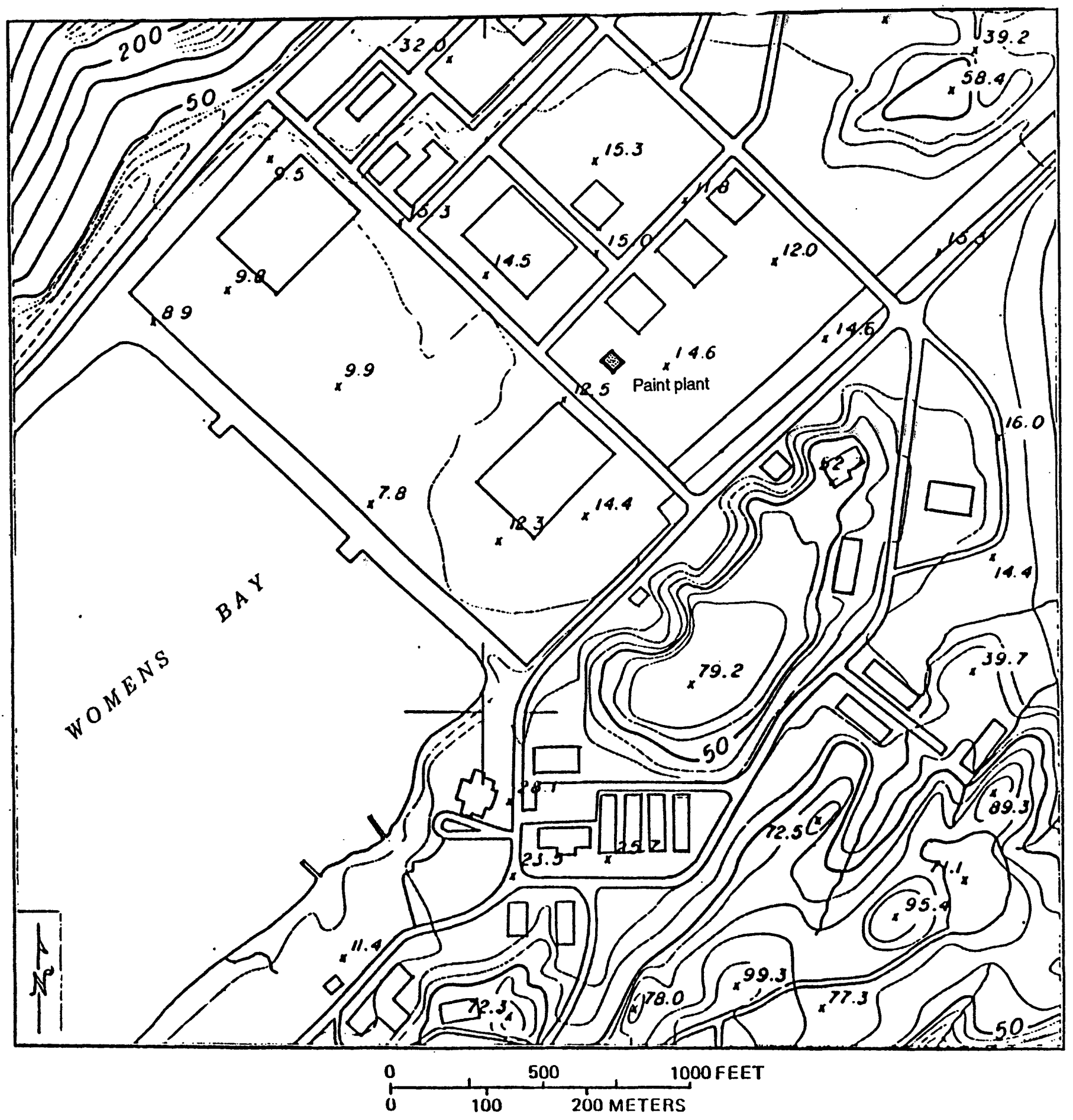

Figure 14. Area 11, the paint plant 


\section{Area 12. Drum Disposal Area West of Buskin Lake}

Area 12 (fig. 15) is an area west of Buskin Lake where about 3,000 drums were discarded. The former contents of the drums are unknown, but most drums now are rusted and all are empty. The reconnaissance soil-gas survey found that organic vapor readings in the air and soils at the site were at background levels. The area is underlain by alluvium of unknown thickness.

No wells were drilled upgradient. Wells A001 and A001A were drilled downgradient from the drum disposal site. One water sample was collected from each well. On May 23, 1989, water levels in wells A001 and A001A were 8.44 and $5.32 \mathrm{ft}$ below land surface. Three soil samples from well A001 and two from A001A were chemically analyzed. Field water-quality properties were also measured from surface-water sites 12 and 13 near Buskin Lake. Discharges at sites 12 and 13 on July 29,1987 were 18 and $3 \mathrm{ft}^{3} / \mathrm{s}$, respectively.

The following selected constituent was detected in water in wells and streams near Area 12:

\begin{tabular}{llll}
\hline Constituent & $\begin{array}{c}\text { CAS } \\
\text { number }\end{array}$ & $\begin{array}{c}\text { SMCL } \\
(\mathrm{mg} / \mathrm{L})\end{array}$ & $\begin{array}{l}\text { Sites having at least one concentration } \\
\text { greater than or equal to the SMCL }\end{array}$ \\
\hline Manganese & 7439965 & 0.05 & A001, A001A \\
\hline
\end{tabular}

All soil samples had detectable concentrations of lead ( 0.3 to $8.4 \mathrm{mg} / \mathrm{kg})$. A soil sample from A001- 00.5 contained $130 \mathrm{mg} / \mathrm{kg} \mathrm{TPH}$, but no organic constituents were detected in the two groundwater samples and no constituents had concentrations exceeding MCL's. 


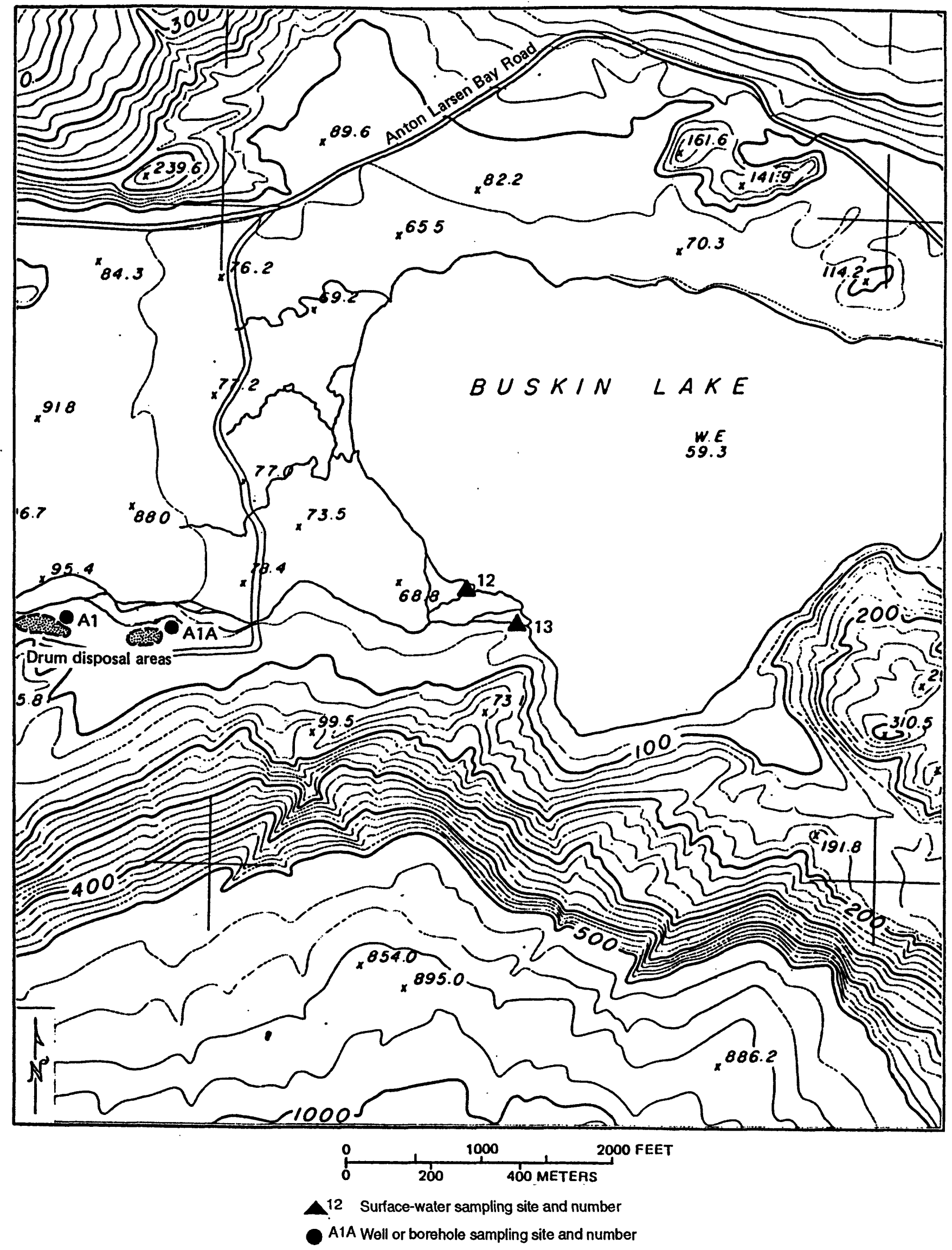

Figure 15. Area 12, a former drum disposal area near Buskin Lake. 


\section{Area 13. Drum Disposal Area Northwest of Buskin Lake}

Area 13 is a drum disposal area north of Buskin Lake (fig. 16). Little is known about the contents of the hundreds of drums reportedly discarded here and subsequently crushed and buried by the U.S. Army Corps of Engineers. The area is underlain by alluvium of unknown thickness.

No upgradient or downgradient wells were drilled. Field water-quality properties were measured from a tributary to Buskin Lake (surface-water site 1) on July 28, 1987. The results are listed below:

\begin{tabular}{lr}
\hline Chemical or property & Value \\
\hline Water temperature & $11.5{ }^{\circ} \mathrm{C}$ \\
Specific conductance & $32 \mu \mathrm{s} / \mathrm{cm}$ \\
pH & $7.0 \mathrm{units}$ \\
Discharge, instantaneous & $0.6 \mathrm{ft}^{3} / \mathrm{s} \mathrm{(estimated)}$ \\
Organic carbon & $0.8 \mathrm{mg} / \mathrm{L} \mathrm{as} \mathrm{C}$ \\
Barometric pressure & $760 \mathrm{~mm}$ of $\mathrm{Hg}$
\end{tabular}

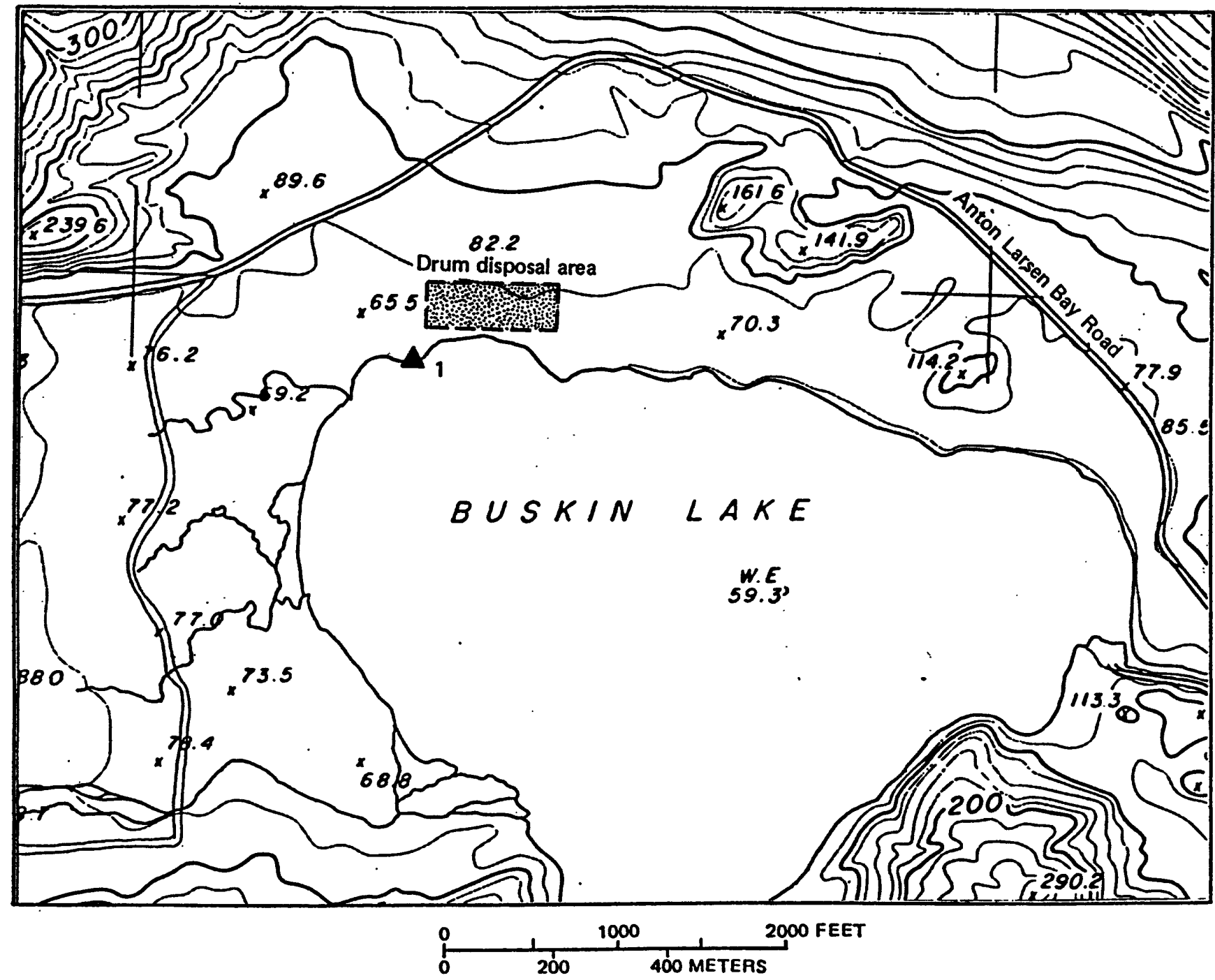

Surface-water sampling sile and number

Figure 16. Area 13, a former drum disposal area near Buskin Lake. 


\section{Area 14. Former Quartermaster Gasoline Station}

Area 14 is a former quartermaster gas station near the intersection of Anton Larsen Bay Road and Old Tom Stiles Road (fig. 17). Underground fuel storage tanks may still be present in the area, which is underlain by gravel fill and alluvium of unknown thickness.

No wells were drilled upgradient. One soil and four water samples from downgradient well A077 were chemically analyzed. Water levels in A077 ranged from 8.68-10.20 ft below land surface. Field water-quality properties were collected from a sample at surface-water site 29 . Three downgradient water-quality samples also were collected from surface-water site 30 on the Buskin River. No organic constituents were detected in the surface-water samples.

The following is a list of selected constituents detected in water from well A077. No constituents were detected at concentrations higher than the MCL's for drinking water.

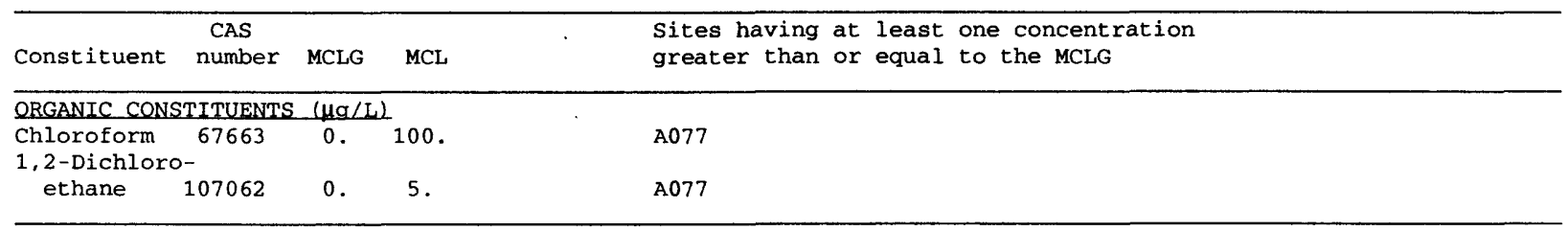

Lead was detected in a soil sample from A077-05 at $5.6 \mathrm{mg} / \mathrm{kg}$. Only two organic constituents were detected in ground-water samples: 1,2 -dichloroethane $(0.78 \mu \mathrm{g} / \mathrm{L})$ and chloroform $(1.5 \mu \mathrm{g} / \mathrm{L})$. The 1,2-dichloroethane, detected in a sample recovered on March 7, 1989, may be a laboratory contaminant. Chloroform, detected in a sample taken on October 5, 1988, may occur in the water naturally. Neither of these constituents were detected in other water samples recovered from well A077 at other times. 


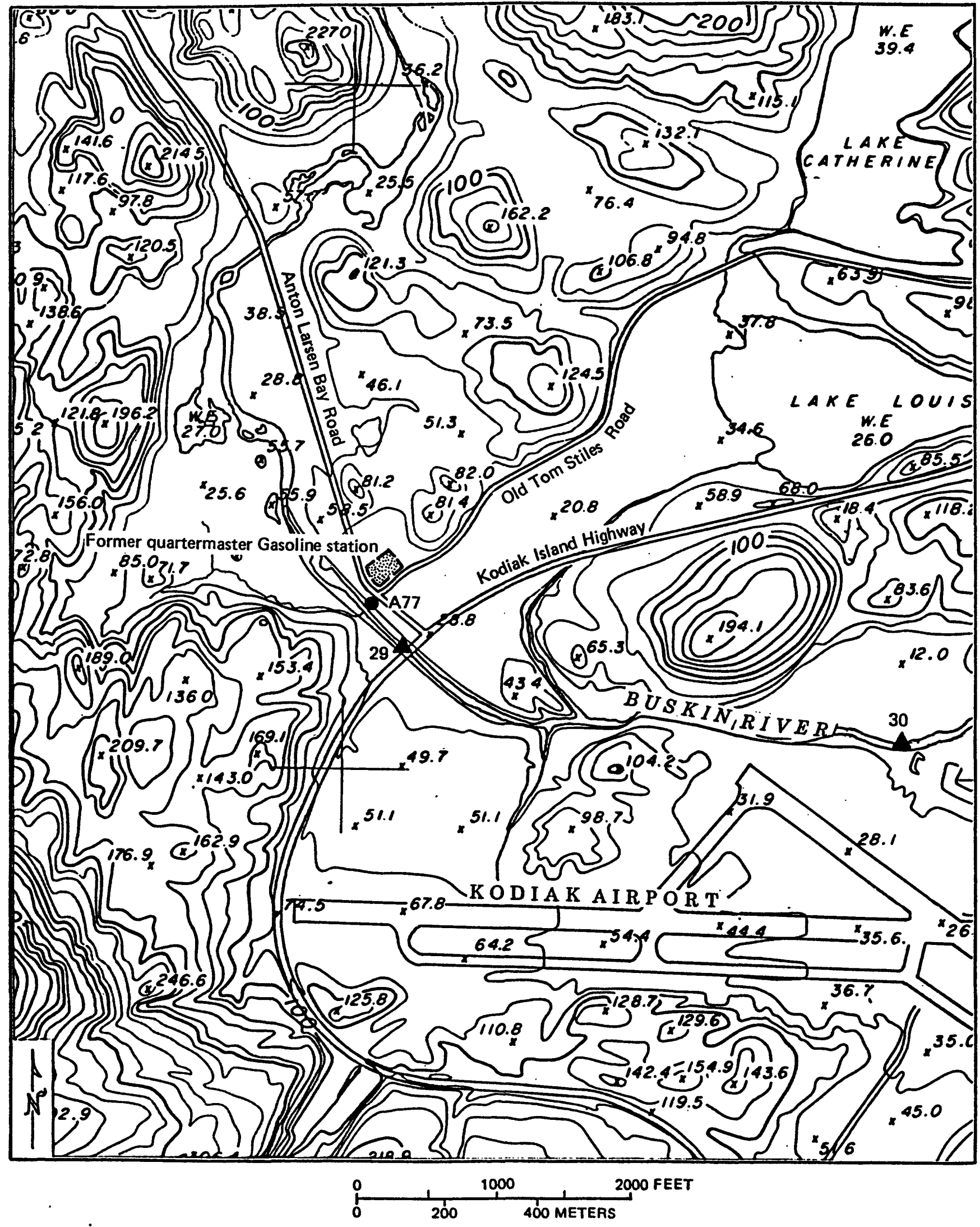

29 Surface-water sampling site and number

A77 Well or borehole sampling site and number

Figure 17. Area 14, the former quartermaster gasoline station. 


\section{Area 15. Former Gasoline Station}

Area 15 is a former gasoline station on G Avenue near Peterson Elementary School (fig. 18). Underground fuel storage tanks have been removed. The area is underlain by gravel fill, alluvium, and glacial till of unknown thicknesses.

Well A016 was drilled upgradient and wells A017 and A082 were drilled downgradient from the gas station. Well A016, however, is downgradient from a metal disposal area (Area 18). Only one soil sample was collected (A082-05); lead was detected in the soil sample at $12 \mathrm{mg} / \mathrm{kg}$. Water levels in the wells, in feet below land surface, were: A016, 14.99-25.04; A017, 23.75-31.48; and A082, 19.84-dry ( $>30.5 \mathrm{ft}$ ). Ground-water samples were collected from three wells, but no surfacewater samples were collected near the former gasoline station.

The following is a list of selected constituents detected in 10 water samples from 3 wells near the former gas station. Concentrations of all constituents were lower than the MCL's for drinking water.

\begin{tabular}{|c|c|c|c|}
\hline Constituent & $\begin{array}{l}\text { CAS } \\
\text { number }\end{array}$ & MCLG & $\begin{array}{l}\text { Sites having at least one concentration } \\
\text { greater than or equal to the MCLG }\end{array}$ \\
\hline \multicolumn{4}{|c|}{ ORGANIC CONSTITUENTS $(\mu \mathrm{g} / \mathrm{L})$} \\
\hline \multicolumn{4}{|c|}{$\begin{array}{l}\text { Chloroform } 67663 \\
1,2 \text {-Dichloro- }\end{array}$} \\
\hline ethane & 107062 & 0 & $\mathrm{~A} 016, \mathrm{~A} 017, \mathrm{~A} 082$ \\
\hline Aluminum & 7429905 & 0.05 & $\mathrm{A082}$ \\
\hline Manganese & 7439965 & 0.05 & $\mathrm{~A} 016, \mathrm{~A} 082$ \\
\hline
\end{tabular}

The following selected constituents do not have MCLG's or SMCL's but were detected in water samples:

\begin{tabular}{lrr}
\hline Constituent & CAS number & Sites having constituent detected at least once \\
\hline Bromodichloromethane & 75274 & A082 \\
Total petroleum hydrocarbons & 5289290400 & A016 \\
\hline
\end{tabular}

Well A082 yielded water having concentrations of bromodichloromethane ranging from $<0.5$ to $1.5 \mu \mathrm{g} / \mathrm{L}$ and chloroform ranging from 2.5 to $24 \mu \mathrm{g} / \mathrm{L}$. 


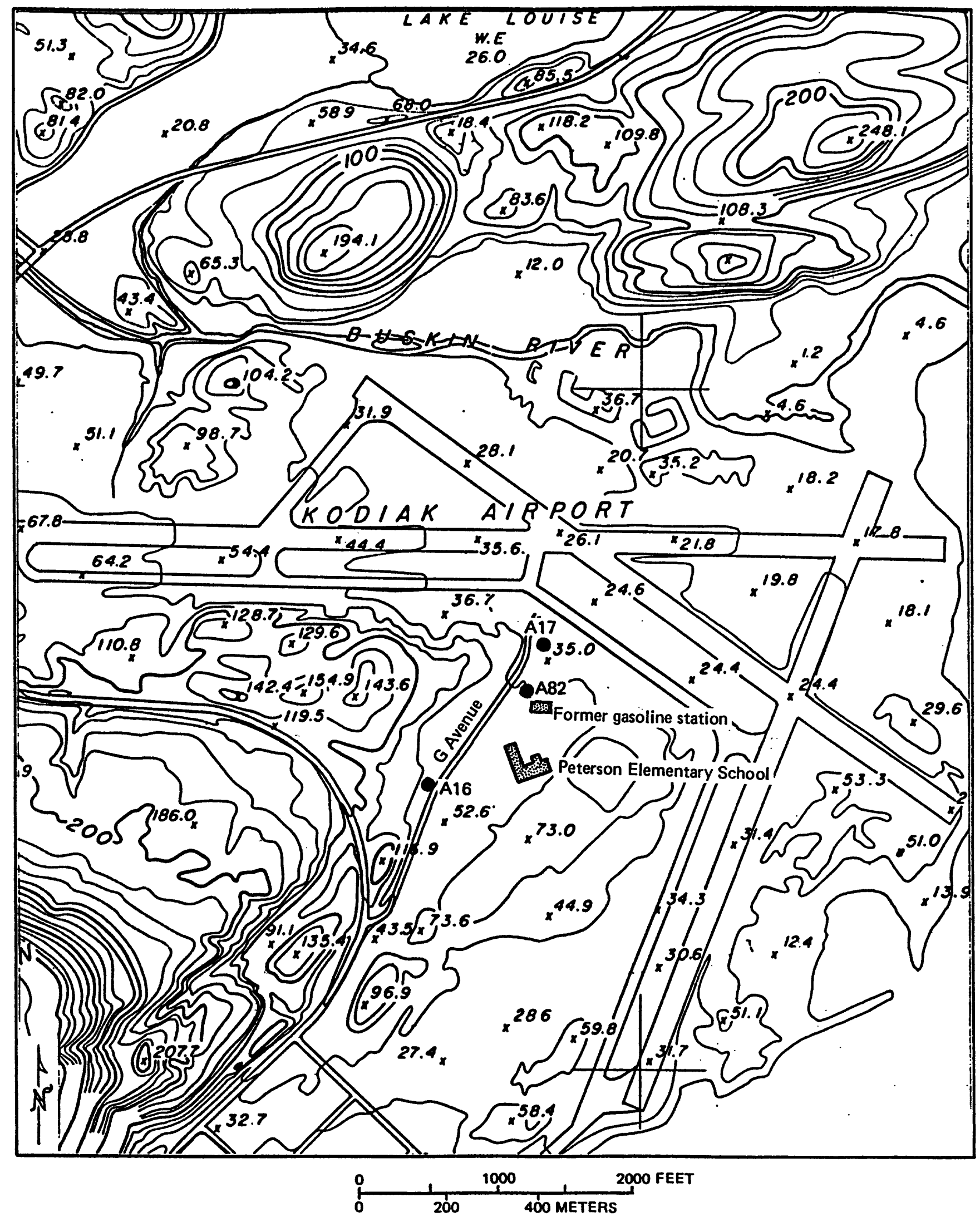

A16 Well or borehole sampling site and number

Figure 18. Area 15, a former gasoline station. 


\section{Area 16. Airport Staging Area}

Area 16 includes most areas at and near the airport (fig. 19) but excludes the burn pit in the former fire-fighting training area (Area 5). Various fuels, which have been and are currently stored here, reportedly have leaked or have been spilled throughout this area. The locations of all buried fuel tanks are not known. The area is underlain by bedrock, gravel fill, and alluvium.

Wells A008, A011, A012, A012A, A013, A020A, A022, A022A, A023, A023A, A079, B001, B002, and B003 were drilled at or downgradient from the airport. Sixteen soil and 32 ground-water samples were collected. Well A023 was not completed and no soil or water samples were recovered from this site. Wells A022 and A022A were dry, thus no water-quality samples were collected from these wells. Water levels in the remaining wells ranged from $3.63 \mathrm{ft}(\mathrm{A011})$ to $38.97 \mathrm{ft}$ below land surface (B002). Surface-water site 32 is upgradient and sites $30,31,34,35,36$, and 60 are downgradient. Two upgradient and 11 downgradient surface-water samples were collected. Streamflows measured in Devils Creek at site 31 during the study ranged from 2.7 to $58 \mathrm{ft}^{3} / \mathrm{s}$. Measured discharges in three drainage channels (sites 34-36) were less than $0.5 \mathrm{ft}^{3} / \mathrm{s}$.

The following is a list of selected constituents detected in water from wells and streams near the airport. Sites listed with an asterisk indicate that the constituent was present at a concentration greater than or equal to the MCL for drinking water.

\begin{tabular}{|c|c|c|c|}
\hline Constituent & $\begin{array}{c}\text { CAS } \\
\text { number }\end{array}$ & MCLG & $\begin{array}{l}\text { Sites having at least one concentration } \\
\text { greater than or equal to the MCLG }\end{array}$ \\
\hline \multicolumn{4}{|c|}{ INORGANIC CONSTITUENTS (mg/L) } \\
\hline Cadmium & 7440439 & 0.005 & $\mathrm{~A} 012 \mathrm{~A} *$ \\
\hline $\begin{array}{l}\text { Lead } \\
\text { Thallium }\end{array}$ & $\begin{array}{l}7439921 \\
7440280\end{array}$ & $\begin{array}{lc}0 . & 0.005 \\
0.0004 & --\end{array}$ & $\begin{array}{l}\mathrm{A} 013, \mathrm{~A} 023 \mathrm{~A}, \mathrm{~A} 025^{*}, \mathrm{~A} 079 * \\
\text { Surface-water site } 34\end{array}$ \\
\hline \multicolumn{4}{|c|}{$\frac{\text { ORGANIC CONSTITUENTS }(\mu \mathrm{g} / \mathrm{L})}{1,2-\mathrm{Dich})}$} \\
\hline ethane & 107062 & $0 . \quad 5$ & $\begin{array}{l}\text { A008, A012, A012A, A013, A020A, A023A, A079; } \\
\text { surface-water sites } 34,35\end{array}$ \\
\hline Constituent & $\begin{array}{l}\text { CAS } \\
\text { number }\end{array}$ & $\begin{array}{l}\text { SMCL } \\
(\mathrm{mg} / \mathrm{L})\end{array}$ & $\begin{array}{l}\text { Sites having at least one concentration } \\
\text { greater than or equal to the SMCL }\end{array}$ \\
\hline $\begin{array}{l}\text { Aluminum } \\
\text { Iron } \\
\text { Manganese }\end{array}$ & $\begin{array}{l}7429905 \\
7439896 \\
7439965\end{array}$ & $\begin{array}{l}0.05 \\
0.3 \\
0.05\end{array}$ & $\begin{array}{l}\mathrm{A} 012 \mathrm{~A}, \mathrm{~A} 020 \mathrm{~A}, \mathrm{~A} 023 \mathrm{~A}, \mathrm{~B} 003 \\
\mathrm{~A} 020 \mathrm{~A}, \mathrm{~A} 023 \mathrm{~A} \\
\mathrm{~A} 008, \mathrm{~A} 013, \mathrm{~A} 020 \mathrm{~A}, \mathrm{~A} 079, \mathrm{~B} 001, \mathrm{~B} 002, \mathrm{~B} 003\end{array}$ \\
\hline
\end{tabular}

The following selected constituents do not have MCLG's or SMCL's but were detected in water samples:

\begin{tabular}{lcl}
\hline Constituent & CAS number & Sites having constituent detected at least once \\
\hline $\begin{array}{l}\text { Trichlorofluoromethane } \\
\text { bis (2-ethylhexy 1)phthalate }\end{array}$ & 75694 & Surface-water site 34 \\
\hline
\end{tabular}

Lead was detected in the 16 soil samples recovered from 11 wells and its concentration ranged from 3.8 to $16 \mathrm{mg} / \mathrm{kg}$. Toluene was detected only in water from one well (B001) at a concentration of $6.5 \mu \mathrm{g} / \mathrm{L}$. 


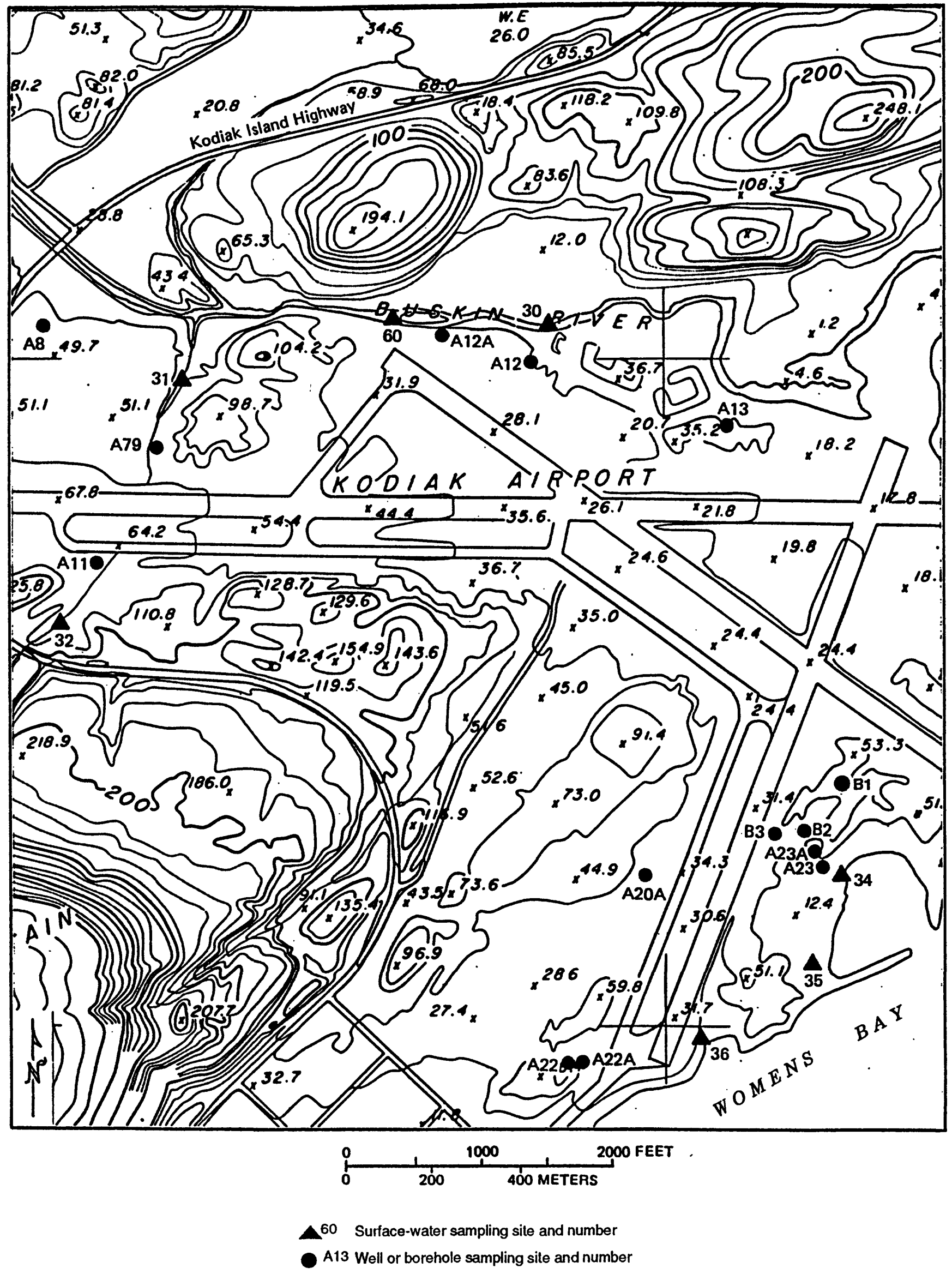

Figure 19. Area 16, the airport staging area. 


\section{Area 17. Storage Pad South of Steam Plant}

Area 17 is an outside storage pad (fig. 20) where paints, painting-related chemicals, and other organic products are stored. Underground tanks that contained heavy oil (FS6) were removed from this site. The area is underlain by a thin layer of gravel fill and bedrock.

Well B007 was drilled near the center of the pad, whereas wells A042 and A086 were drilled downgradient northwest of the site. Water levels in well B007 ranged from 2.52 to $3.68 \mathrm{ft}$ below land surface. Soil samples were obtained at A042-05, A086-05, B007-0.5, and B007-03. Groundwater samples were analyzed from wells A042, A086, and B007; four each from A042 and A086 and one from B007. Two downgradient surface-water samples were collected at site 40 .

The following is a list of selected constituents detected in water in three wells and a stream near the storage pad:

\begin{tabular}{|c|c|c|c|}
\hline Constituent & $\begin{array}{c}\text { CAS } \\
\text { number }\end{array}$ & MCLG & $\begin{array}{l}\text { Sites having at least one concentration } \\
\text { greater than or equal to the MCLG }\end{array}$ \\
\hline \multicolumn{4}{|c|}{ INORGANIC CONSTITUENTS (mg/L) } \\
\hline $\begin{array}{l}\text { Arsenic } \\
\text { Lead }\end{array}$ & $\begin{array}{l}7440382 \\
7439921\end{array}$ & $\begin{array}{ll}0 . & 0.05 \\
0 . & 0.005\end{array}$ & $\begin{array}{l}\mathrm{A} 042, \mathrm{~A} 086 \\
\mathrm{~A} 042, \mathrm{~A} 086\end{array}$ \\
\hline \multicolumn{4}{|c|}{ ORGANIC CONSTITUENTS $(\mu \mathrm{g} / \mathrm{L})$} \\
\hline \multicolumn{2}{|c|}{ Chloroform 67663} & 0.100 & Surface-water site 40 \\
\hline $\begin{array}{l}\text { 1,2-Dichlor } \\
\text { ethane } \\
\text { PCB }\end{array}$ & $\begin{array}{r}107062 \\
2767792\end{array}$ & $\begin{array}{l}5 . \\
0.5\end{array}$ & $\begin{array}{l}\text { A042, A086; surface-water site } 40 \\
\text { Surface-water site } 40\end{array}$ \\
\hline Constituent & $\begin{array}{l}\text { CAS } \\
\text { number }\end{array}$ & $\begin{array}{l}\text { SMCL } \\
(\mathrm{mg} / \mathrm{L})\end{array}$ & $\begin{array}{l}\text { Sites having at least one concentration } \\
\text { greater than or equal to the SMCL }\end{array}$ \\
\hline $\begin{array}{l}\text { Chloride } \\
\text { Aluminum } \\
\text { Iron } \\
\text { Manganese }\end{array}$ & $\begin{array}{r}1003 \\
7429905 \\
7439896 \\
7439965\end{array}$ & $\begin{array}{l}250 . \\
0.05 \\
0.3 \\
0.05\end{array}$ & $\begin{array}{l}\text { A086, } \\
\text { A042, A086, B007 } \\
\text { A086 } \\
\text { A086, B007 }\end{array}$ \\
\hline
\end{tabular}

The following selected constituent does not have MCLG's or SMCL's but was detected in water samples:

\begin{tabular}{lll}
\hline Constituent & CAS number & Sites having constituent detected at least once \\
\hline Total petroleum hydrocarbons. & 5289290400 & B 007
\end{tabular}

Lead was detected in all soil samples ranging from 10 to $16 \mathrm{mg} / \mathrm{kg}$. TPH's were detected in soils from well A042 at $280 \mathrm{mg} / \mathrm{kg}$. Well B007 yielded water having a TPH concentration of $17 \mathrm{mg} / \mathrm{L}$ but no detectable volatile organics or lead. Well A042 may be affected by Womens Bay as specific conductance of water from the well ranged from 356 to $1,780 \mu \mathrm{S} / \mathrm{cm}$. PCB's were detected in water at surface-water site 40 at $0.1 \mu \mathrm{g} / \mathrm{L}$. 


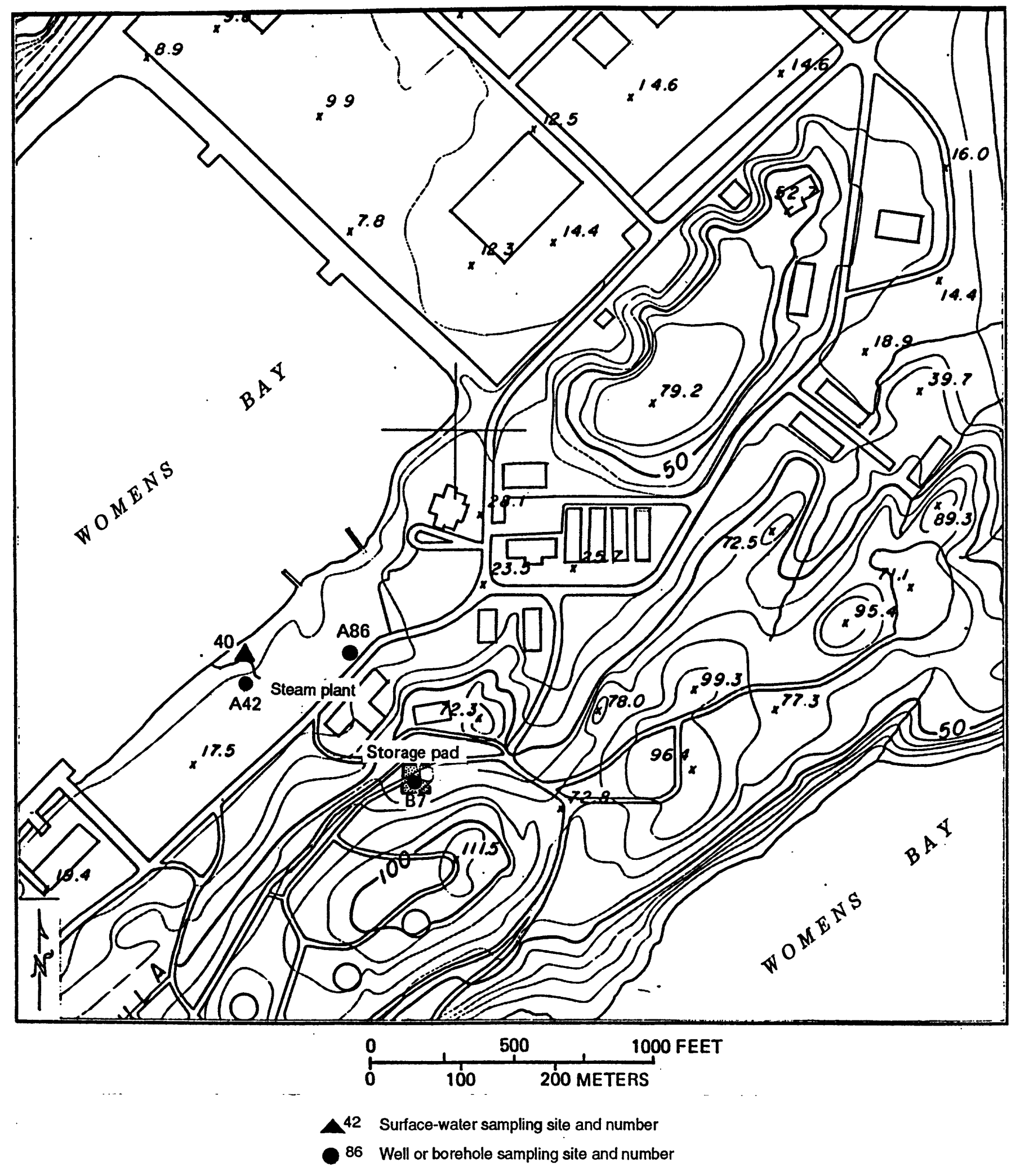

Figure 20. Area 17, a storage pad south of the steam plant. 


\section{Area 18. Former Metal Disposal Area}

Area 18 is in Drury Gulch (fig. 21) where a variety of metallic refuse was discarded. Electric transformers that contained PCB's were stored, emptied, burned, and buried there. Much of the area is underlain by sand, gravel, and cobbles that overlie bedrock.

No wells were drilled upgradient from the metal disposal area. Wells A016 and A081 were drilled downgradient. Water levels in well A016 ranged from 14.99 to $25.04 \mathrm{ft}$ below land surface and water levels in A081 ranged from 1.11 to $10.05 \mathrm{ft}$ below land surface. A soil sample was analyzed from well A081 and three water-quality samples were analyzed from each of wells A016 and A081. Three downgradient surface-water samples were collected at Drury Gulch at Kodiak Island Highway (site 33). Discharges measured at site 33 ranged from $<0.01$ to $0.05 \mathrm{ft}^{3} / \mathrm{s}$.

The following is a list of selected constituents detected in water in the two wells and Drury Gulch. An asterisk indicates that the site had a concentration of that constituent that was greater than or equal to the MCL for drinking water.

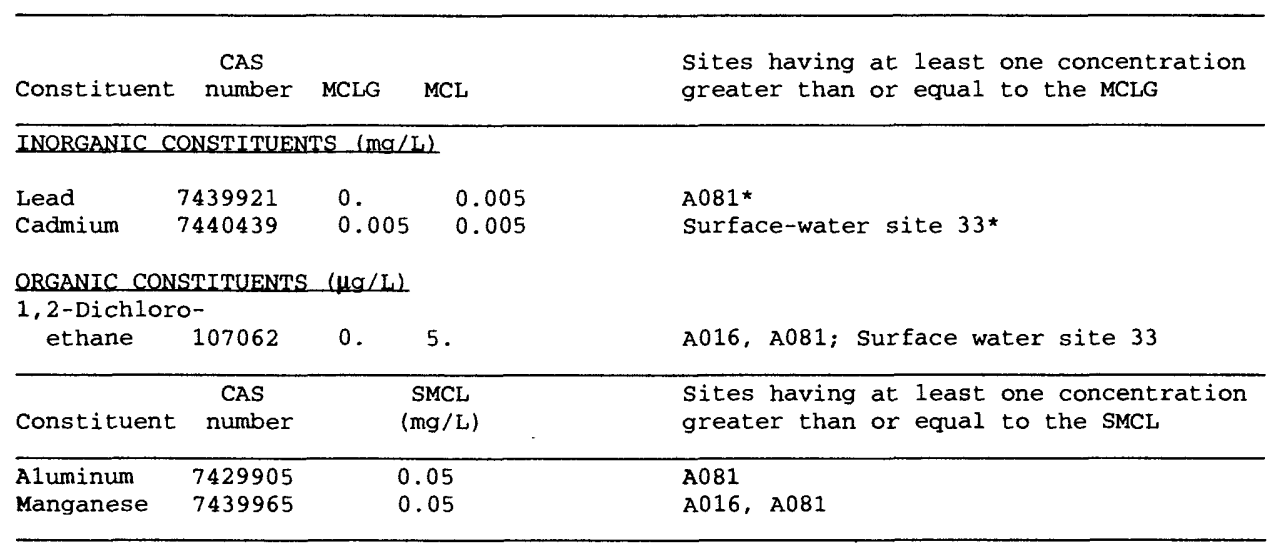

The following selected constituent does not have MCLG's or SMCL's but was detected in water samples:

\begin{tabular}{lll}
\hline Constituent & CAS number & site having constituent detected at least once \\
\hline Tota1 petroleum hydrocarbons & 5289290400 & A016
\end{tabular}

Lead was detected in a soil sample from A081-05 at $8.2 \mathrm{mg} / \mathrm{kg}$. Lead was once detected at a concentration of $0.01 \mathrm{mg} / \mathrm{L}$ in water from A081, but in three other samples from the well had concentrations $<0.02 \mathrm{mg} / \mathrm{L}$. The concentration of TPH in water from well A016 was $0.9 \mathrm{mg} / \mathrm{L}$. No PCB's, dioxins, or furans were detected in water from well A081 or from surface-water site 33. 


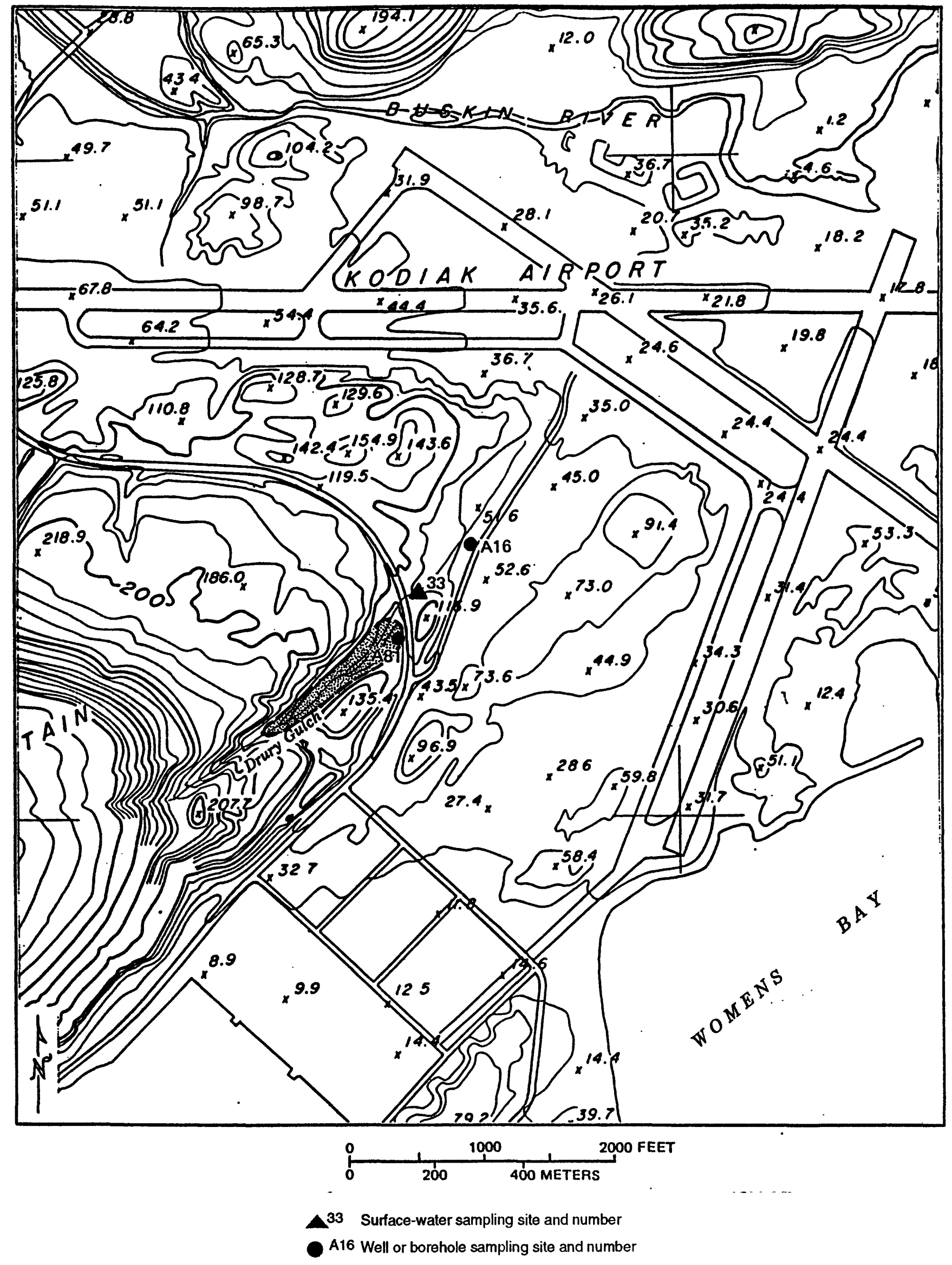

Figure 21. Area 18, a former metal disposal area. 


\section{SUMMARY}

The USCG Support Center on Kodiak Island was established during World War II as a U.S. Navy base. It served as a naval submarine base, air base, and port during and after the war, and was acquired by the USCG in 1972. The shallow geology of the area is characterized by a thin cover of unconsolidated sediments, but bedrock is commonly exposed. About 100 wells were installed by the USGS to help develop a general understanding of the regional ground-water system and to examine locations and potential sources of suspected contamination. Eighteen areas of potential contamination were identified and studied. Many of these areas are near the ocean, thus surface and ground water within or downgradient from these areas may be affected by brackish sea water.

The water supply for the Center is Buskin Lake. Only one well (CG 4) supplies water to a building outside of the water-distribution system and the well is upgradient from all known sources of contamination. No organic constituents were detected in water from CG 4, but chloroform and bromodichloromethane were detected in samples of chlorine-treated water from the water-distribution system.

Sixty-eight quality-control "blank" water samples were analyzed to monitor potential contamination from the collection, transport, storage, and analysis of water samples. Methylene chloride was detected in 26 blanks at concentrations as great as $5.9 \mu \mathrm{g} / \mathrm{L}$ and 1,2-dichloroethane was detected in 15 blanks at concentrations as great as $2.6 \mu \mathrm{g} / \mathrm{L}$. The presence of these organic constituents is likely due to sampling or laboratory contamination.

Two lake-bed-material samples and more than 100 soil samples were chemically analyzed. Total Petroleum Hydrocarbons were detected at 16 sites. O- \& p-xylenes and tetrachloroethene were detected at three sites; toluene was detected at two sites; and vinyl chloride, methylene chloride, trichloroethene, and $\mathrm{m}$-xylene were each detected once. Lead, which occurs naturally in soils, was detected at all but one site and ranged from 0.3 to $100 \mathrm{mg} / \mathrm{kg}$. The average concentration of lead was $10.6 \mathrm{mg} / \mathrm{kg}$.

Approximately 350 ground-water samples were collected from 101 wells; 110 surface-water samples were collected from 59 sites on streams or lakes. Cadmium, lead, thallium, benzene, tetrachloroethene, trichloroethene, and vinyl chloride were detected at a concentration higher than allowed by primary drinking-water regulations. Arsenic, cadmium, lead, sulfate, thallium, benzene, chloroform, 1,2-dichloroethane, methylene chloride, tetrachloroethene, 1,1,1-trichloroethane, trichloroethene, vinyl chloride, PCB's, and styrene were detected at concentrations higher than Maximum Contaminant Level Goals.

Water samples from 10 wells and 18 surface-water sites were analyzed to obtain background or upgradient conditions. Aluminum, iron, and manganese were present in water at several sites at concentrations higher than the Secondary Maximum Contaminant Levels for drinking water. Low concentrations of arsenic, lead, and chloroform were also found. The constituent 1,2-dichloroethane was found in several ground-water samples, but its presence may be due to a sampling or laboratory contaminant as it was also detected in several quality-control blanks.

Water present downgradient from a landfill (Area 1) that operated from the early 1970's until 1987 contained 1,2-dichloroethane, vinyl chloride, and TPH in low $(<3 \mu \mathrm{g} / \mathrm{L})$ concentrations. Bis(2-ethylhexyl)pthalate was present at $460 \mu \mathrm{g} / \mathrm{L}$ in a water sample from a drain south of the landfill, but was not detected at a $10 \mu \mathrm{g} / \mathrm{L}$ level in a subsequent sample. 
Before 1972 another landfill (Area 2) was used. Vinyl chloride, the only constituent found in concentrations exceeding MCL's for drinking water, was detected in surface water recovered from a ditch near the landfill. The maximum vinyl chloride concentration at this site was $15 \mu \mathrm{g} / \mathrm{L}$. Benzene, 1,2-dichloroethane, methylene chloride, and dichlorodifluoromethane were detected at concentrations less than $5 \mu \mathrm{g} / \mathrm{L}$.

High concentrations of vinyl chloride, tetrachloroethene, and trichloroethene are present in ground water near a laundry facility (Area 3 ) where dry-cleaning wastes were discarded onto the ground. The maximum concentrations for vinyl chloride, tetrachloroethene, and trichloroethene were $440,3,000$, and $49 \mu \mathrm{g} / \mathrm{L}$ respectively. Constituents present in ground water at concentrations less than $5 \mu \mathrm{g} / \mathrm{L}$ include chloroform and 1,2-dichloroethane. Methylene chloride was present at $180 \mu \mathrm{g} / \mathrm{L}$ in a water sample from well A039, but was not detected at the $2 \mu \mathrm{g} / \mathrm{L}$ level in three other samples collected at other times from the same well.

Toluene and 1,2-dichloroethane were each detected at low concentrations $(<3 \mu \mathrm{g} / \mathrm{L})$ once, but were not detected three other times in water from a well near a former diesel storage area (Area 4).

Concentrations of TPH as high as $38,100 \mathrm{mg} / \mathrm{kg}$ were found in soils in a burn pit at a former fire-fighting training area (Area 5). Organic constituents detected in ground water include chloromethane $(3.3 \mu \mathrm{g} / \mathrm{L})$, trichlorofluoromethane $(27 \mu \mathrm{g} / \mathrm{L})$, and toluene $(6.5 \mu \mathrm{g} / \mathrm{L})$. Trichlorofluoromethane and 1,2-dichloroethane were also detected at concentrations less than $1 \mu \mathrm{g} / \mathrm{L}$ in water from a stream near the fire training area.

Fuels and lubricants have been, and continue to be, stored at several locations on Nyman Peninsula (Area 6). Seven large above-ground storage tanks contain jet fuel, oil, and waste oil and have underground distribution lines. Within Area 6 are other storage areas for fuel and non-fuel chemicals (Areas 7 and 17) and batteries (Area 8). Nine of 52 soil samples had detectable concentrations of TPH, but only one sample had detectable concentrations of toluene and xylenes. Some of the organic constituents detected in ground water include benzene, toluene, ethylbenzene, xylenes, chloroform and 1,2-dichloroethane. The highest concentrations observed were $17 \mu \mathrm{g} / \mathrm{L}$ benzene, $15 \mu \mathrm{g} / \mathrm{L}$ toluene, $33 \mu \mathrm{g} / \mathrm{L}$ ethylbenzene, 33 and $140 \mu \mathrm{g} / \mathrm{L}$ m-xylene and o- \& p-xylenes, $31 \mu \mathrm{g} / \mathrm{L}$ chloroform, and $1.9 \mu \mathrm{g} / \mathrm{L}$ 1,2-dichloroethane. Surface-water samples had few organic constituents at concentrations above reporting levels. Benzene, ethylbenzene, and xylenes were not detected in any surface-water samples. The highest concentrations of toluene and chloroform detected in surface water were 0.3 and $5.5 \mu \mathrm{g} / \mathrm{L}$, respectively.

Two former drum-storage areas made up Area 7, which is within the fuel-storage tank area (Area 6) on Nyman Peninsula. Benzene was detected in two wells at concentrations as great as 8.3 and $17 \mu \mathrm{g} / \mathrm{L}$, but concentrations in both wells were also below detection levels $(0.7 \mu \mathrm{g} / \mathrm{L})$ at other times. One of these wells yielded water having dissolved lead concentrations of 0.19 and $0.11 \mathrm{mg} / \mathrm{L}$.

Two battery storage areas make up Area 8, which is in the fuel storage tank area (Area 6). The highest lead concentration in ground water was $0.005 \mathrm{mg} / \mathrm{L}$ and all observed concentrations of mercury were $<0.0001 \mathrm{mg} / \mathrm{L}$. The lowest observed $\mathrm{pH}$ was 5.8 units and was from water from an upgradient well.

Aviation gasoline was stored at the eastern end of Nyman Peninsula (Area 9). The highest concentration of TPH found in soils in Area 9 was $170 \mathrm{mg} / \mathrm{kg}$. One well yielded water containing as much as $0.02 \mathrm{mg} / \mathrm{L}$ lead, $15 \mu \mathrm{g} / \mathrm{L}$ benzene, $76 \mu \mathrm{g} / \mathrm{L}$ toluene, $250 \mu \mathrm{g} / \mathrm{L}$ ethylbenzene, $150 \mu \mathrm{g} / \mathrm{L}$ 
m-xylene, and $150 \mu \mathrm{g} / \mathrm{L}$ o- \& p-xylenes. Water from another well had trichloroethene and tetrachloroethene concentrations as high as 66 and $20 \mu \mathrm{g} / \mathrm{L}$, respectively.

A well at the air station (Area 10) near where jet fuel was spilled in 1987 yielded water having concentrations as high as $78 \mu \mathrm{g} / \mathrm{L}$ benzene, $18 \mu \mathrm{g} / \mathrm{L}$ toluene, $140 \mu \mathrm{g} / \mathrm{L}$ ethylbenzene, $55 \mu \mathrm{g} / \mathrm{L} \mathrm{m}$ xylene, $170 \mu \mathrm{g} / \mathrm{L}$ o- \& p-xylenes, and $9.2 \mathrm{mg} / \mathrm{L} \mathrm{TPH}$.

No wells were drilled near a paint plant (Area 11) on the air station or a drum disposal site (Area 13) north of Buskin Lake because surveys made using an organic vapor analyzer found that readings in air and in soils were at background levels.

No organic constituents were detected in ground water from two wells at a drum disposal site (Area 12) west of Buskin Lake, but a soil sample contained $130 \mathrm{mg} / \mathrm{kg}$ TPH.

A well near a former quartermaster gasoline station (Area 14) yielded water having low concentrations of chloroform $(1.5 \mu \mathrm{g} / \mathrm{L})$.

A well near another former gasoline station (Area 15) yielded water having concentrations of bromodichloromethane as high as $1.5 \mu \mathrm{g} / \mathrm{L}$ and chloroform as high as $24 \mu \mathrm{g} / \mathrm{L}$.

Thirteen wells were drilled near the airport (Area 16). Toluene was detected only in water from one well at a concentration of $6.5 \mu \mathrm{g} / \mathrm{L}$.

The concentration of TPH was $17 \mathrm{mg} / \mathrm{L}$ in water from a well in an area where paints are stored (Area 17). No volatile organic compounds or lead were detected in water from the well.

The only organic constituent detected in water from wells near a metal-disposal site (Area 18) was 1,2-dichloroethane. No PCB's were detected.

\section{REFERENCES CITED}

Alaska Department of Environmental Conservation, 1990, Interim guidance for soil cleanup levels (Draft, March 1, 1990): Alaska Department of Environmental Conservation, Memorandum, 13 p.

Allely, R.D.,1989, Shallow seismic-refraction profiling of the U.S. Coast Guard Reservation, Kodiak, Alaska: Alaska Department of Natural Resources, Division of Geological and Geophysical Surveys, Public Data File 89-8C, 73 p.

American Public Health Association, American Water Works Association, and Water Pollution Control Federation, 1980, Standard methods for the examination of water and wastewater (15th ed.): Washington, D.C., 1134 p. 1985, Standard methods for the examination of water and wastewater (16th ed.): Washington, D.C., 1268 p.

American Society for Testing and Materials, 1964, Manual on industrial water and industrial waste water: Philadelphia, $856 \mathrm{p}$. 1966, Manual on industrial water and industrial waste water ( $2 \mathrm{~d}$ ed.): Philadelphia, $992 \mathrm{p}$. 1978, Manual on water (4th ed.), Hamilton, D.E., (ed.): Philadelphia, 472 p.

Brown, J.M., 1989, Bedrock geotechnical properties affecting ground-water movement in the U.S. Coast Guard Reservation, Kodiak, Alaska: Alaska Department of Natural Resources, Division of Geological and Geophysical Surveys, Public Data File 89-8D, 11 p.

Carr, M.R.,1996, Description of wells drilled at the U.S. Coast Guard Support Center Kodiak, Alaska, 1988-89: U.S. Geological Survey Open-File Report 96-134, 233 p. 
Combellick, R.A., 1989, Surficial geology of the U.S. Coast Guard Reservation, Kodiak, Alaska: Alaska Department of Natural Resources, Division of Geological and Geophysical Surveys, Public Data File 89-8B, 54 p.

Enseco, 1988, Quality assurance program plan for environmental chemical monitoring, revision 3.2: Enseco Incorporated, Arvada, Colorado, $49 \mathrm{p}$.

Leslie, L.D., 1989, Alaska climate summaries (2d ed.): University of Alaska-Anchorage, Alaska Climate Center Technical Note No. 5.

Lucius, J.E., Olhoeft, G.R., Hill, P.L., and Duke, S.K., 1989, Properties and hazards of 108 selected substances: U.S. Geological Survey Open-File Report 89-491, 538 p.

National Oceanic and Atmospheric Administration, 1987-89, Climatological data: published monthly.

Solie, D.N., and Reifenstuhl, R.R., 1989, Bedrock geology of U.S. Coast Guard Reservation, Kodiak, Alaska: Alaska Department of Natural Resources, Division of Geological and Geophysical Surveys, Public Data File 89-8A, $32 \mathrm{p}$.

Solin, G.L., 1996, Overview of surface-water resources at the U.S Coast Guard Support Center Kodiak, Alaska: U.S. Geological Survey Open-File Report 96-463, 18 p. +2 plates.

U.S. Environmental Protection Agency, 1979, Methods for chemical analysis of water and wastes: Environmental Protection Agency, Office of Research and Development, EPA-6001-4-79-020.

1986, Test methods for evaluating solid waste--physical/chemical methods: Environmental Protection Agency Report SW-846 (3rd ed.).

1987, Guidelines establishing test procedures for the analysis of pollutants: U.S. Code of Federal Regulations, Title 40, Part 136, revised as of July 1, 1987.

1995, Drinking water regulations and health advisories, U. S. Environmental Protection Agency, Office of Water, $11 \mathrm{p}$. 


\section{APPENDIXES 1-7}

1. Description of methods used to analyze soil and water

2. Physical and chemical characteristics of soil and lake-bed material

3. Physical and chemical characteristics of ground water

4. Physical and chemical characteristics of surface water

5. Ground-water levels

6. Surface-water data-collection sites and miscellaneous streamflow measurements, U.S. Coast Guard Support Center Kodiak

7. Water-surface elevations of selected streams and lakes, U.S. Coast Guard Support Center Kodiak 


\section{ALL APPENDIXES ARE ON DISKS}

\section{Data Disk Information}

On disk 1 there is an ASCII file named README.TXT. It says:

This text file contains an overview of the files available on these data disks.

Report title:

Hydrologic and water-quality data for U.S. Coast Guard Support Center Kodiak, Alaska, 1987-89 by R.L. Glass, 1996

U.S. Geological Survey Open File Report 96-498

For additional information write to:

District Chief US Geological Survey 4230 University Drive, Suite 201 Anchorage, Alaska, 99508-4664

These disks contain the data from the appendixes. They are 3.5-inch, 1.44 megabyte disks formatted with the IBM PC operating system MS-DOS. Data tables are written in ASCII format with semicolons delimiting data columns with .TXT extension. Descriptions of the contents of each data file are included in ASCII files with .HDR extension. For example, the contents of Appendix 1 are described in the file APPEND1.HDR and the data are in APPEND1.TXT

A list of the appendixes is given on the next page and a paper copy of the first page of each appendix is given on the following pages, as samples. 
Explanation of the appendixes on the disks:

\begin{tabular}{|c|c|c|c|}
\hline $\begin{array}{l}\text { Appendix } \\
\text { No. }\end{array}$ & Disk No. & File name & File description \\
\hline 1 & 1 & APPEND1.HDR & Describes contents of APPEND1.TXT \\
\hline 1 & 1 & APPEND1.TXT & Analytical methods used to analyze soil and water \\
\hline 2 & 1 & APPEND2.HDR & Describes contents of APPEND2.TXT \\
\hline 2 & 1 & APPEND2.TXT & Physical and chemical characteristics of soil and lake-bed \\
\hline 3 & 1 & APPEND3.HDR & Describes contents of APPEND3.TXT \\
\hline $3 \mathrm{~A}$ & 1 & APPEND3A.TXT & Physical and chemical characteristics of ground water \\
\hline 3B & 2 & APPEND3B.TXT & Physical and chemical characteristics of ground water \\
\hline $3 \mathrm{C}$ & 2 & APPEND3C.TXT & Physical and chemical characteristics of ground water \\
\hline 4 & 3 & APPEND4.HDR & Describes contents of APPEND4.TXT \\
\hline $4 \mathrm{~A}$ & 3 & APPEND4A.TXT & Physical and chemical characteristics of surface water \\
\hline $4 B$ & 3 & APPEND4B.TXT & Physical and chemical characteristics of surface water \\
\hline 5 & 1 & APPEND5.HDR & Describes contents of APPEND5.TXT \\
\hline 5 & 1 & APPEND5.TXT & Ground-water levels \\
\hline 6 & 1 & APPEND6.HDR & Describes contents of APPEND6.TXT \\
\hline 6 & 1 & APPEND6.TXT & Streamflow measurements \\
\hline 7 & 1 & APPEND7.HDR & Describes contents of APPEND7.TXT \\
\hline 7 & 1 & APPEND7.TXT & Water-surface elevations of selected streams and lakes \\
\hline
\end{tabular}




\section{APPENDIX 1 SAMPLE PAGE}

Appendix 1.-Description of methods used to analyze soil and water

The ASCII file APPEND1.TXT is 429 lines and describes the methods used to analyze soil and water.

The first thirty six lines of the file APPEND1.TXT appear after the column-count line

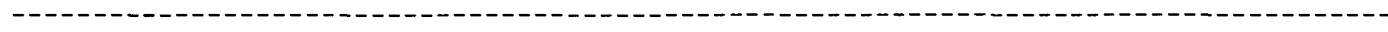

$\begin{array}{lllllllll}1 & 2 & 3 & 4 & 5 & 6 & 7 & 8 & 9\end{array}$

1234567890123456789012345678901234567890123456789012345678901234567890123456789012345678901234567890

Appendix 1.--Description of methods used to analyze soil and water

Al29 or E300 - Common Anions

A method which utilizes an ion chromatograph to determine the concentrations of anions in water.

Anion $\begin{aligned} & \text { Reporting level } \\ & (\mathrm{mg} / \mathrm{L})\end{aligned}$

$\begin{array}{ll}\text { Chloride } & 0.5 \\ \text { Fluoride } & 0.5 \\ \text { Nitrate } & 0.5 \\ \text { Sulfate } & 0.5\end{array}$

A403 - Alkalinity

The alkalinity of a solution is defined as the capacity for solutes it contains to react with and neutralize acid. The property of alkalinity is determined by titration with strong acid, and the end point of the titration is the $\mathrm{pH}$ at which virtually all solutes contributing to alkalinity have reacted. In almost all natural waters the alkalinity is produced mainly by the dissolved carbon dioxide species, bicarbonate, carbonate and hydroxide. The titration end points used were at pH 4.5 and 8.3. The property of alkalinity is reported in terms of an equivalent calcium carbonate.

$\begin{array}{ll}\text { Property } & \begin{array}{l}\text { Reporting level } \\ \text { (mg/L) }\end{array}\end{array}$

Alkalinity, Total as $\mathrm{CaCO} 3$ at $\mathrm{pH} 4.5 \quad 5$

Alkalinity, Bicarbonate at pH $4.5 \quad 5$

Alkalinity, Carbonate at $\mathrm{pH} 8.3 \quad 5$

Alkalinity, Hydroxide 5 


\section{APPENDIX 2 SAMPLE PAGE}

Appendix 2.-Physical and chemical characteristics of soil and lake-bed material samples

The ASCII file APPEND2.TXT is 4,829 lines and contains the following semicolon-delimited data:

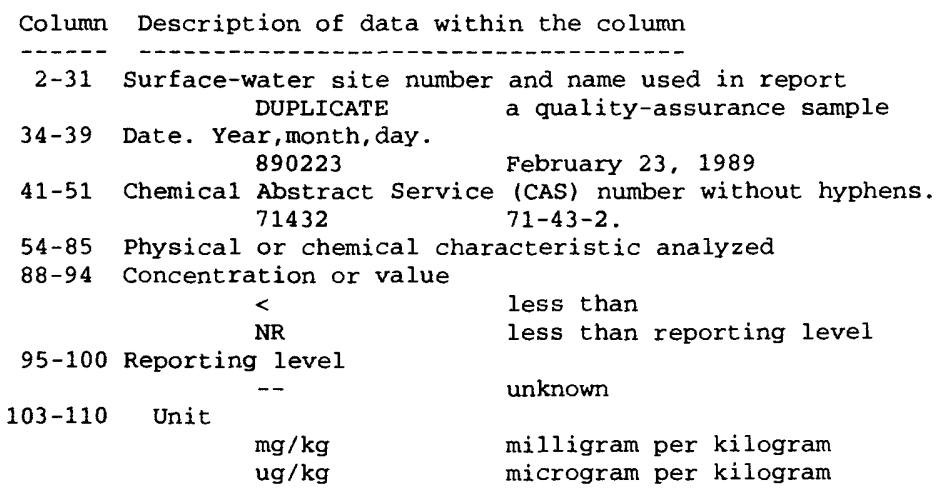

The first thirty lines of the file APPEND1.TXT appear after the column-count line

The first thirty lines of the file ApenDl . TXT appear after the column-count 1 ine

$\begin{array}{llllllllllll}0 & 1 & 2 & 3 & 4 & 5 & 6 & 1 & 9 & 9 & 1\end{array}$

12345678901234567890123456789012345678901234567890123456789012345678901234567890123456789012345678901234567890

\begin{tabular}{|c|c|c|c|c|c|c|c|}
\hline ample & locat & ion & & ; & Date & CAS nu & ysical or \\
\hline 25-RED & LAKE & (BED & MATERIAL) & ; & 890223 ; & $1008 ;$ & Total Solids \\
\hline 25-RED & LAKE & (BED & MATERIAL) & ; & 890223 ; & 50328 ; & Benzo (a) pyrene \\
\hline 25-RED & LAKE & (BED & MATERIAL) & ; & 890223 ; & $51285 ;$ & 2,4-Dinitrophenol \\
\hline 25-RED & LAKE & (BED & MATERIAL) & ; & 890223 ; & 53703 ; & Dibenz $(a, h)$ anthracene \\
\hline 25-RED & LAKE & (BED & MATERIAL) & ; & 890223 ; & 56235 ; & Carbon tetrachloride \\
\hline 25-RED & LAKE & (BED & MATERIAL) & ; & $890223 ;$ & $56495 ;$ & 3-Methylcholanthrene \\
\hline 25-RED & LAKE & (BED & MATERIAL) & ; & $890223 ;$ & $56553 ;$ & Benzo (a) anthracene \\
\hline 25-RED & LAKE & (BED & MATERIAL) & ; & 890223 ; & 57976 ; & 7,12-Dimethylbenz-anthracene \\
\hline 25-RED & LAKE & (BED & MATERIAL) & ; & 890223 ; & $58902 ;$ & $2,3,4,6$-Tetrachlorophenol \\
\hline 25-RED & LAKE & (BED & MATERIAL) & ; & 890223 ; & 59507 ; & 4-Chloro-3-methylphenol \\
\hline 25-RED & LAKE & (BED & MATERIAL) & ; & 890223 ; & $60117 ;$ & p-Dimethylaminoazobenzene \\
\hline 25-RED & LAKE & (BED & MATERIAL) & ; & $890223 ;$ & $62442 ;$ & Phenacetin \\
\hline 25-RED & LAKE & (BED & MATERIAL) & ; & 890223 ; & $62500 ;$ & Ethyl methanesulfonate \\
\hline 25-RED & LAKE & (BED & MATERIAL) & ; & 890223 ; & $62533 ;$ & Aniline \\
\hline 25-RED & LAKE & (BED & MATERIAL) & ; & $890223 ;$ & $62759 ;$ & N-Nitrosodimethy lamine \\
\hline 25-RED & LAKE & (BED & MATERIAL) & ; & 890223 ; & $65850 ;$ & Benzoic acid \\
\hline 25-RED & LAKE & (BED & MATERIAL) & ; & $890223 ;$ & $66273 ;$ & Methyl methanesulfonate \\
\hline 25-RED & LAKE & (BED & MATERIAL) & ; & 890223 ; & $67663 ;$ & Chloroform \\
\hline 25-RED & LAKE & (BED & MATERIAL) & ; & 890223 ; & $67721 ;$ & Hexachloroethane \\
\hline 25-RED & LAKE & (BED & MATERIAL) & ; & $890223 ;$ & 71432 ; & Benzene \\
\hline 25-RED & LAKE & (BED & MATERIAL) & ; & 890223 ; & $71556 ;$ & 1,1,1-Trichloroethane \\
\hline 25-RED & LAKE & (BED & MATERIAL) & ; & 890223 ; & $74839 ;$ & Bromomethane \\
\hline 25-RED & LAKE & (BED & MATERIAL) & ; & 890223 ; & 74873 ; & Chloromethane \\
\hline 25-RED & LAKE & (BED & MATERIAL) & ; & $890223 ;$ & $74953 ;$ & Dibromomethane \\
\hline 25-RED & LAKE & (BED & MATERIAL) & ; & $890223 ;$ & $75003 ;$ & Chloroethane \\
\hline 25-RED & LAKE & (BED & MATERIAL) & ; & 890223 ; & $75014 ;$ & Vinyl chloride \\
\hline 25-RED & LAKE & (BED & MATERIAL) & ; & 890223 ; & $75092 ;$ & Methylene chloride \\
\hline 25-RED & LAKE & (BED & MATERIAL) & ; & $890223 ;$ & $75252 ;$ & Bromoform \\
\hline 25-RED & LAKE & (BED & MATERIAL) & ; & $890223 ;$ & $75274 ;$ & Bromodichloromethane \\
\hline
\end{tabular}

\begin{tabular}{|c|c|c|}
\hline Bn & $\mathrm{NV} ;$ & Undt \\
\hline $16.8 ;$ & 0.1 ; & Percent \\
\hline$<0.50 ;$ & 0.50 ; & $\mathrm{mg} / \mathrm{kg}$ \\
\hline$<1.5$ & $1.5 ;$ & $\mathrm{mg} / \mathrm{kg}$ \\
\hline$<0.50 ;$ & 0.50 ; & $\mathrm{mg} / \mathrm{kg}$ \\
\hline$<0.10 ;$ & 0.10 ; & $\mathrm{mg} / \mathrm{kg}$ \\
\hline$<2.5$ & 2.5 ; & $\mathrm{mg} / \mathrm{kg}$ \\
\hline$<0.50$; & 0.50 ; & $\mathrm{mg} / \mathrm{kg}$ \\
\hline$<2.5$ & 2.5; & $\mathrm{mg} / \mathrm{kg}$ \\
\hline$<2.5$ & 2.5; & $\mathrm{mg} / \mathrm{kg}$ \\
\hline$<0.50 ;$ & 0.50 ; & $\mathrm{mg} / \mathrm{kg}$ \\
\hline$<2.5$ & $2.5 ;$ & $\mathrm{mg} / \mathrm{kg}$ \\
\hline$<2.5$ & 2.5 ; & $\mathrm{mg} / \mathrm{kg}$ \\
\hline$<2.5$ & 2.5 ; & $\mathrm{mg} / \mathrm{kg}$ \\
\hline$<2.5 i$ & 2.5; & $\mathrm{mg} / \mathrm{kg}$ \\
\hline$<2.5$ & $2.5 i$ & $\mathrm{mg} / \mathrm{kg}$ \\
\hline$<2.5$ & $2.5 ;$ & $\mathrm{mg} / \mathrm{kg}$ \\
\hline$<2.5$ & 2.5; & $\mathrm{mg} / \mathrm{kg}$ \\
\hline$<0.10$ & 0.10 ; & $\mathrm{mg} / \mathrm{kg}$ \\
\hline$<0.50$ & 0.50 ; & $\mathrm{Ing} / \mathrm{kg}$ \\
\hline$<0.20$ & 0.20 ; & $\mathrm{mg} / \mathrm{kg}$ \\
\hline$<0.10$ & 0.10 ; & $\mathrm{mg} / \mathrm{kg}$ \\
\hline$<0.1$ & $0.1 ;$ & $\mathrm{mg} / \mathrm{kg}$ \\
\hline$<0.1$ & $0.1 ;$ & $\mathrm{mg} / \mathrm{kg}$ \\
\hline$<0.10$ & 0.10 ; & $\mathrm{mg} / \mathrm{kg}$ \\
\hline$<0.10$ & 0.10 ; & $\mathrm{mg} / \mathrm{kg}$ \\
\hline$<0.10$ & $0.10 ;$ & $\mathrm{mg} / \mathrm{kg}$ \\
\hline$<0.10$ & 0.10 ; & $\mathrm{mg} / \mathrm{kg}$ \\
\hline$<0.10$ & $0.10 ;$ & $\mathrm{mg} / \mathrm{kg}$ \\
\hline$<0.10$ & $0.10 ;$ & $\mathrm{mg} / \mathrm{kg}$ \\
\hline
\end{tabular}


APPENDIX 3 SAMPLE PAGE

Appendix 3.-Physical and chemical characteristics of ground water

The original ASCII file APPEND3.TXT was 18,960 lines and has been divided into three files which contain the following semicolon-delimited data:

Column Description

2-11 Ground-water site number used in report

DUPLICATE a quality-assurance duplicate sample

14-19 Date. Year/month/day. $890523 \quad$ May 23, 1989

21-31 Chemical Abstract Service (CAS) number without hyphens. For example, 71432 represents 71-43-2. Numbers less than 1000 are not CAS numbers but are arbitrary numbers assigned to field-measured properties such as water temperature (10), specific conductance (95), ground-water level (237), and $\mathrm{pH}(400)$.

34-61 physical or chemical characteristic analyzed

63-72 Concentration or value

74-81 Reporting level or detection limit

84-93 Unit not specified or unknown

uS/cm microsiemens per centimeter $\mathrm{mg} / \mathrm{L} \quad$ milligram per liter ug/L microgram per liter

APPEND3A.TXT contains water-quality results from wells A001 through A021A-DUPLICATE and is 5,383 ines APPEND3B.TXT contains water-quality results from wells A023A through A052-DUPLICATE and is 5, 899 ines APPEND3C.TXT contains water-quality results from wells A053 through CG 4 and is 7,679 ines

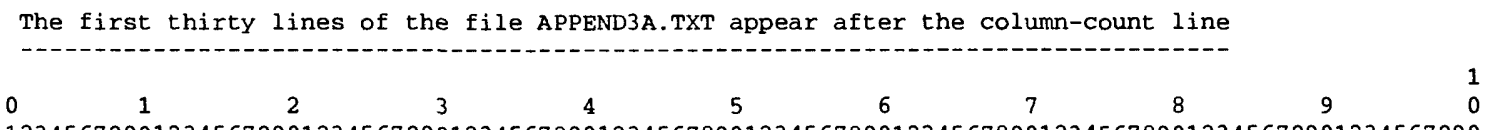

1234567890123456789012345678901234567890123456789012345678901234567890123456789012345678901234567890

\begin{tabular}{|c|c|c|c|c|c|c|c|c|c|c|}
\hline Site no. & ; & Date & CAS number; & Physical or $\mathrm{c}$ & & & & & L; & Un \\
\hline A001 & ; & $890523 ;$ & $10 ;$ & Temperature & ; & 3 & ; & - & ; & DEGREE C \\
\hline A001 & ; & $890523 ;$ & $95 ;$ & Specific conductance & $;$ & 58 & ; & - & ; & $\mathrm{us} / \mathrm{cm}$ \\
\hline A001 & ; & $890523 ;$ & 400 ; & $\mathrm{pH}$ & ; & 7.3 & ; & - & ; & STD UNITS \\
\hline A001 & ; & $890523 ;$ & 1003; & Chloride & ; & 3.5 & ; & 0.7 & ; & $\mathrm{mg} / \mathrm{L}$ \\
\hline A001 & ; & 890523 ; & 1010; & Total Dissolved Solids & ; & 43. & ; & 10. & ; & $\mathrm{mg} / \mathrm{L}$ \\
\hline A001 & ; & 890523 ; & $3035 ;$ & Sulfate & ; & 3.2 & ; & 0.5 & ; & $\mathrm{mg} / \mathrm{L}$ \\
\hline $\mathrm{A} 001$ & ; & $890523 ;$ & $25900 ;$ & Nitrate as $\mathrm{N}$ & ; & $<0.5$ & ; & 0.5 & ; & $\mathrm{mg} / \mathrm{L}$ \\
\hline A001 & ; & 890523; & 56235 ; & Carbon tetrachloride & ; & $<0.60$ & ; & 0.60 & ; & $\mathrm{ug} / \mathrm{L}$ \\
\hline A001 & ; & $890523 ;$ & $66300 ;$ & Fluoride & $;$ & $<0.5$ & ; & 0.5 & $;$ & $\mathrm{mg} / \mathrm{L}$ \\
\hline A001 & ; & 890523 ; & $67663 ;$ & Chloroform & ; & $<0.30$ & ; & 0.30 & ; & $\mathrm{ug} / \mathrm{L}$ \\
\hline$A 001$ & ; & 890523 ; & $71432 ;$ & Benzene & ; & $<0.70$ & ; & 0.70 & $;$ & $\mathrm{ug} / \overline{\mathrm{L}}$ \\
\hline A001 & ; & $890523 ;$ & $71556 ;$ & 1,1,1-Trichloroethane & ; & $<0.20$ & ; & 0.20 & ; & $\mathrm{ug} / \mathrm{L}$ \\
\hline A001 & ; & 890523 ; & 74839 ; & Bromomethane & $;$ & $<6.0$ & ; & 6.0 & ; & $\mathrm{ug} / \mathrm{L}$ \\
\hline A001 & ; & 890523 ; & $74873 ;$ & Chloromethane & ; & $<1.1$ & ; & 1.1 & ; & $\mathrm{ug} / \mathrm{L}$ \\
\hline A001 & ; & 890523 ; & $74953 ;$ & Dibromomethane & ; & $<5.0$ & ; & 5.0 & ; & $\mathrm{ug} / \mathrm{L}$ \\
\hline A001 & ; & 890523 ; & $75003 ;$ & Chloroethane & ; & $<3.0$ & ; & 3.0 & ; & $\mathrm{ug} / \mathrm{L}$ \\
\hline A001 & ; & 890523 ; & $75014 ;$ & Vinyl chloride & ; & $<0.60$ & ; & 0.60 & ; & $\mathrm{ug} / \mathrm{L}$ \\
\hline$A 001$ & ; & 890523 ; & $75092 ;$ & Methylene chloride & $;$ & $<2.0$ & ; & 2.0 & ; & $\mathrm{ug} / \mathrm{L}$ \\
\hline $\mathrm{A} 001$ & ; & $890523 ;$ & $75252 ;$ & Bromoform & ; & $<1.0$ & ; & 1.0 & ; & $\mathrm{ug} / \mathrm{L}$ \\
\hline A001 & ; & $890523 ;$ & $75274 ;$ & Bromodichloromethane & ; & $<0.50$ & ; & 0.50 & ; & $\mathrm{ug} / \mathrm{L}$ \\
\hline A001 & ; & 890523 ; & $75343 ;$ & 1,1-Dichloroethane & ; & $<0.40$ & ; & 0.40 & ; & $\mathrm{ug} / \mathrm{L}$ \\
\hline A001 & ; & 890523 ; & $75354 ;$ & 1,1-Dichloroethene & ; & $<0.70$ & ; & 0.70 & ; & $\mathrm{ug} / \mathrm{L}$ \\
\hline $\mathrm{A} 001$ & ; & $890523 ;$ & $75694 ;$ & Trichlorofluoromethane & ; & $<5.0$ & ; & 5.0 & ; & $\mathrm{ug} / \mathrm{L}$ \\
\hline A001 & ; & $890523 ;$ & $75718 ;$ & Dichlorodifluoromethane & ; & $<9.0$ & ; & 9.0 & $;$ & $\mathrm{ug} / \mathrm{L}$ \\
\hline A001 & ; & 890523; & $78875 ;$ & 1,2-Dichloropropane & ; & $<0.50$ & ; & 0.50 & $;$ & $\mathrm{ug} / \mathrm{L}$ \\
\hline A001 & ; & $890523 ;$ & $79005 ;$ & $1,1,2$-Trichloroethane & ; & $<0.20$ & ; & 0.20 & ; & $\mathrm{ug} / \mathrm{L}$ \\
\hline A001 & ; & 890523 ; & $79016 ;$ & Trichloroethene & ; & $<0.60$ & ; & 0.60 & ; & $\mathrm{ug} / \mathrm{L}$ \\
\hline A001 & ; & $890523 ;$ & $79345 ;$ & $1,1,2,2$-Tetrachloroethane & ; & $<1.4$ & $;$ & 1.4 & $;$ & $\mathrm{ug} / \mathrm{L}$ \\
\hline $\mathrm{A} 001$ & ; & $890523 ;$ & $95501 ;$ & 1,2-Dichlorobenzene & ; & $<0.50$ & ; & 0.50 & ; & $\mathrm{ug} / \mathrm{L}$ \\
\hline
\end{tabular}




\section{APPENDIX 4 SAMPLE PAGE}

Appendix 4.-Physical and chemical characteristics of surface water

The original ASCII file APPEND4.TXT was 9,548 lines and has been divided into two files that contains the following semicolon-delimited data:

Column Description

2-35 Surface-water site number and name used in report DUPLICATE A quality-assurance duplicate sample

38-43 Date. Year/month/day $870728 \quad$ July 28,1987

45-55 Chemical Abstract Service (CAS) number without hyphens. For example, 71432 represents 71-43-2. Numbers less than 1000 are not CAS numbers but are arbitrary numbers assigned to field-measured properties such as water temperature (10), stream discharge (61), specific conductance (95), and $\mathrm{pH}(400)$.

58-87 Physical or chemical characteristic analyzed

89-98 Concentration or value $<\quad$ Less than

100-107 Reporting level Estimated

110-120 Unit -- Unknown

$\begin{array}{ll}\text { FT3/S } & \text { cubic feet per second } \\ \text { US/Cm } & \text { microsiemens per centimeter } \\ \text { mg/L } & \text { milligram per liter } \\ \text { ug/L } & \text { microgram per liter }\end{array}$

APPEND4A.TXT contains water-quality results from surface-water sites 1 through 30 and is 4,961 ines APPEND4B.TXT contains water-quality results from surface-water sites 31 through TW 2 and is 4,587 ines

The first thirty lines of the file APPEND4A.TXT appear after the column-count line

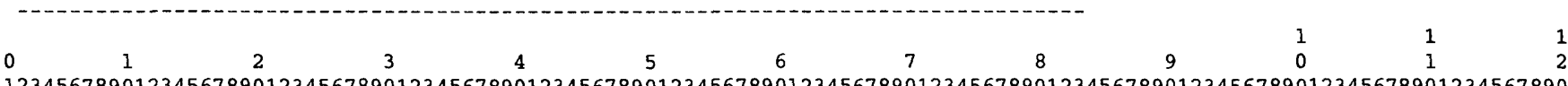

123456789012345678901234567890123456789012345678901234567890123456789012345678901234567890123456789012345678901234567890

Site

Date ;

01-BUSKIN LK TRIB (NORTH-NORTHWEST; 870728

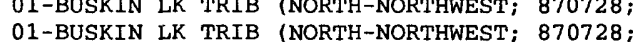

01-BUSKIN LK TRIB (NORTH-NORTHWEST; 870728 ;

01-BUSKIN LK TRIB (NORTH-NORTHWEST; 870728 ;

01-BUSKIN LK TRIB (NORTH-NORTHWEST; 870728;

01-BUSKIN LK TRIB (NORTH-NORTHWEST; 870728 ;

02-BUSKIN LK TRIB (NORTHWEST)

02-BUSKIN LK TRIB (NORTHWEST)

02-BUSKIN LK TRIB (NORTHWEST)

02-BUSKIN LK TRIB (NORTHWEST)

02-BUSKIN LK TRIB (NORTHWEST)

02-BUSKIN LK TRIB (NORTHWEST)

02-BUSKIN LK TRIB (NORTHWEST)

02-BUSKIN LK TRIB (NORTHWEST)

02-BUSKIN LK TRIB (NORTHWEST)

02-BUSKIN LK TRIB (NORTHWEST)

03-BUSKIN LK TRIB (WEST)

03-BUSKIN LK TRIB (WEST)

03-BUSKIN LK TRIB (WEST)

03-BUSKIN LK TRIB (WEST)

03-BUSKIN LK TRIB (WEST)

03-BUSKIN LK TRIB (WEST)

03-BUSKIN LK TRIB (WEST)

03-BUSKIN LK TRIB (WEST)

03-BUSKIN LK TRIB (WEST)

03-BUSKIN LK TRIB (WEST)

04-BUSKIN LK, STA 1

04-BUSKIN LK, STA 1
; 870728;

; 870728;

; 870728

; 870728;

; 870728

; 870728 .

; 870728;

; 870728

; 870728 ;

; 870728;

; 870728;

- 870728

; 870728

; 870728 ;

; 870728 ;

; 870728

; 870728;

- 870728 .

; 870728 .

; 870728 ;

; 880725

; 880725
CAS number; Physical or chemical Character; Conctra 10; Water temperature

61; Discharge, instantaneous

95; Specific conductance

300; Oxygen dissolved

$400 ; \mathrm{pH}$

7440440; Carbon organic

-; Barometric pressure

10; Water temperature

61; Discharge, instantaneous

95; Specific conductance

300; Oxygen dissolved

$400 ; \mathrm{pH}$

1003; Chloride dissolved

7440440; Carbon organic

-; Barometric pressure

-; Specific conductance microsiem

-; Alkalinity

10; Water temperature

61; Discharge, instantaneous

95; Specific conductance

300: Oxygen dissolved

$400 ; \mathrm{pH}$

1003; Chloride dissolved

; 11.5

; E0.6

; 32

; 12.6

; 7.00

; 0.8

; 760

; 8.0

$: 7.6$

; 34

; 10.8

; 6.70

; 4.3

; 0.4

760

; 760

; 13

; 8.5

; 0.45

; 34

; 10.5

; 6.70

i 4.4

; 0.4

- Barometric pressure

; 760

-; Specific conductance microsiem; 46

-; Alkalinity

10; water temperature

10; water temperature
; ReportLv; Unit

; - ; DEGREE $C$

; $\quad$; FT3/S

; $\quad$; uS/cm

; $\mathrm{mg} / \mathrm{L}$

; STD UNITS

img/L AS C

; MM OF HG

; DEGREE C

; FT3/S

; $\mathrm{uS} / \mathrm{cm}$

; $\mathrm{mg} / \mathrm{L}$

; STD UNITS

; $\mathrm{mg} / \mathrm{L}$

; $\mathrm{mg} / \mathrm{L}$ AS C

- MM OF HG

; $\mathrm{mS} / \mathrm{cm}$

; $\mathrm{mg} / \mathrm{L}$

; DEGREE C

; FT3/S

; us/cm

; $\mathrm{mg} / \mathrm{L}$

; STD UNITS

; $\mathrm{mg} / \mathrm{L}$

; $\mathrm{mg} / \mathrm{L}$ AS C

; MM OF HG

i $\mathrm{ms} / \mathrm{cm}$

- $\mathrm{mg} / \mathrm{L}$

; DEGREE C

; DEGREE C 


\section{APPENDIX 5 SAMPLE PAGE}

Appendix 5.-Ground-water levels

The ASCII file APPEND5.TXT is 1,627 lines and contains the following data.

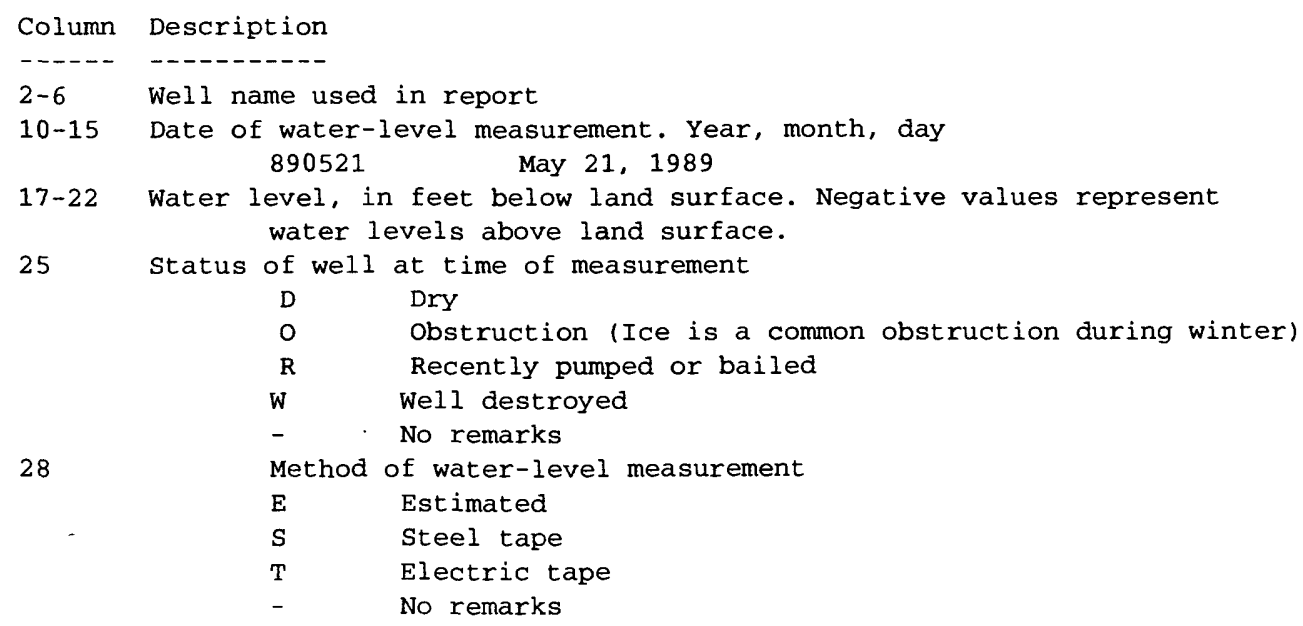




\section{APPENDIX 6 SAMPLE PAGE}

Appendix 6.-Surface-water data-collection sites and miscellaneous streamflow measurements, U.S. Coast Guard Support Center Kodiak

The ASCII file APPEND6.TXT is 132 lines and contains the following semicolon-delimited data:

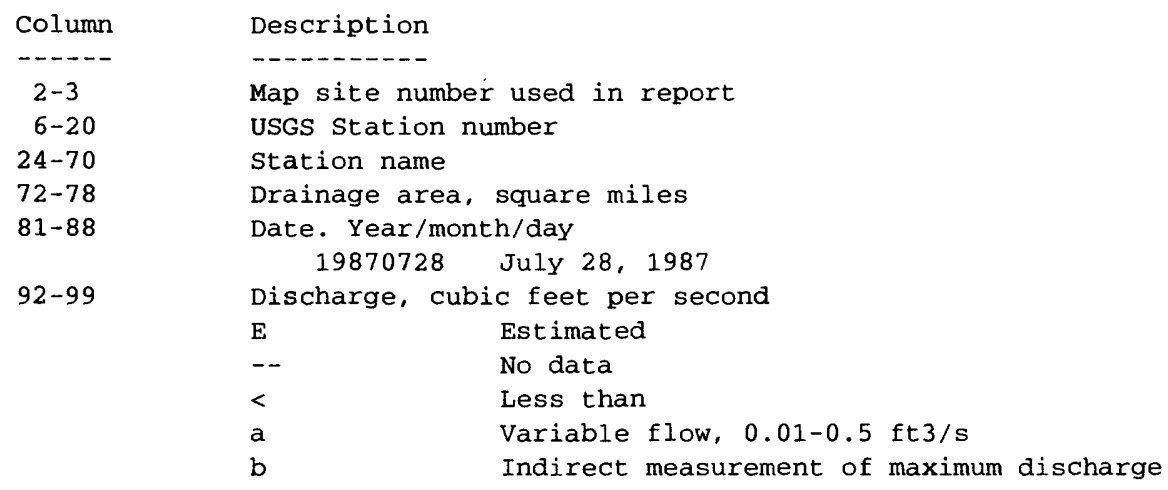

The first thirty lines of the file APPEND6.TXT appear after the column-count 1ine

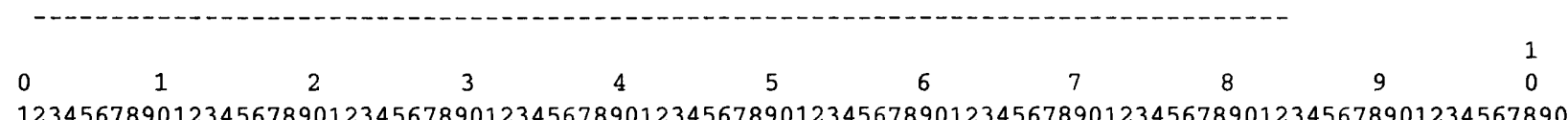

\begin{tabular}{|c|c|c|c|c|c|}
\hline ; & DArea & ; & Date & ; & Discharge \\
\hline ; & -- & ; & 19870728 & ; & E0. 60 \\
\hline ; & -- & ; & 19870728 & ; & 7.6 \\
\hline ; & -- & ; & 19870728 & ; & 0.45 \\
\hline ; & -- & ; & -- & ; & -- \\
\hline i & 3.35 & ; & 19890224 & ; & 2.4 \\
\hline ; & -- & ; & -- & ; & -- \\
\hline ; & 12.0 & ; & 19590717 & ; & 43 \\
\hline ; & 12.0 & ; & 19870728 & ; & 48 \\
\hline ; & 12.0 & ; & 19870819 & ; & 20 \\
\hline ; & 12.0 & ; & 19880510 & ; & 191 \\
\hline ; & 12.0 & ; & 19880724 & ; & 87 \\
\hline ; & 12.0 & ; & 19890224 & ; & 16 \\
\hline ; & -- & ; & 19870731 & ; & $E<0.01$ \\
\hline ; & -- & ; & 19880719 & ; & 0.02 \\
\hline ; & -- & ; & 19870730 & ; & E0. 20 \\
\hline ; & -- & ; & 19870730 & ; & $\mathrm{EO} .40$ \\
\hline ; & -- & ; & 19890224 & ; & 1.1 \\
\hline ; & -- & ; & 19870729 & ; & 18 \\
\hline ; & -- & ; & 19870729 & ; & 3.0 \\
\hline ; & -- & ; & 19890224 & ; & 18 \\
\hline ; & 1.49 & ; & 19880510 & ; & 21 \\
\hline ; & 1.49 & ; & 19880724 & ; & 4.4 \\
\hline ; & 1.49 & ; & 19880816 & ; & 0 \\
\hline ; & 1.49 & ; & 19890224 & ; & 0 \\
\hline ; & -- & ; & 19870728 & ; & E0.04 \\
\hline ; & -- & ; & 19870819 & ; & 0 \\
\hline ; & -- & ; & 19890224 & ; & 0 \\
\hline ; & 17.4 & ; & 19870728 & ; & 49 \\
\hline ; & 17.4 & ; & 19870819 & ; & 18 \\
\hline
\end{tabular}




\section{APPENDIX 7 SAMPLE PAGE}

Appendix 7. Water-surface elevations of selected streams and lakes, U.S. Coast Guard Support Center Kodiak

The file APPEND7.TXT is an ASCII file that contains the following semicolon-delimited data:

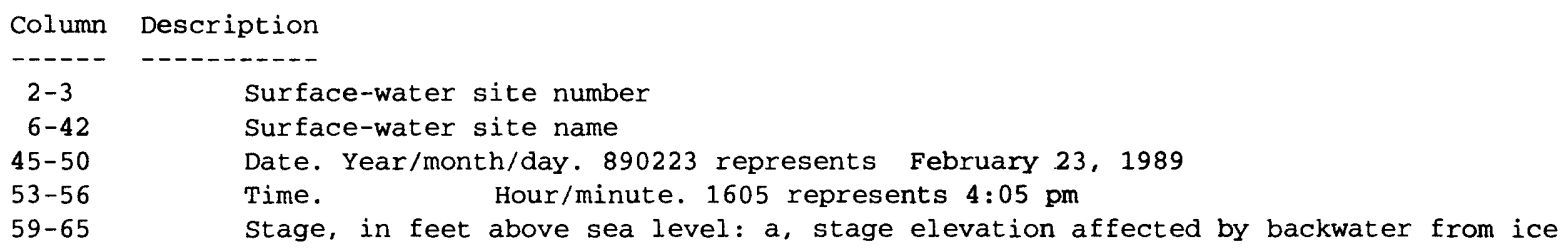

